\title{
Temporal Changes in Soil Carbon Concentration and Quality in a Reclaimed Minesoil Chronosequence
}

\author{
Sriroop Chaudhuri \\ West Virginia University
}

Follow this and additional works at: https://researchrepository.wvu.edu/etd

\section{Recommended Citation}

Chaudhuri, Sriroop, "Temporal Changes in Soil Carbon Concentration and Quality in a Reclaimed Minesoil Chronosequence" (2011). Graduate Theses, Dissertations, and Problem Reports. 4704.

https://researchrepository.wvu.edu/etd/4704

This Dissertation is protected by copyright and/or related rights. It has been brought to you by the The Research Repository @ WVU with permission from the rights-holder(s). You are free to use this Dissertation in any way that is permitted by the copyright and related rights legislation that applies to your use. For other uses you must obtain permission from the rights-holder(s) directly, unless additional rights are indicated by a Creative Commons license in the record and/ or on the work itself. This Dissertation has been accepted for inclusion in WVU Graduate Theses, Dissertations, and Problem Reports collection by an authorized administrator of The Research Repository @ WVU.

For more information, please contact researchrepository@mail.wvu.edu. 


\title{
Temporal Changes in Soil Carbon Concentration and Quality in a Reclaimed Minesoil Chronosequence
}

\author{
Sriroop Chaudhuri
}

Dissertation submitted to the Davis College of Agriculture, Natural Resources and Design at West Virginia University in partial fulfillment of the requirements for the degree of

\author{
Doctor of Philosophy \\ in \\ Agricultural Sciences
}

\author{
Louis M. McDonald, Ph.D., Co-Chair \\ Eugenia-Pena Yewtukhiw, Ph.D., Co-chair \\ Jeffrey Skousen, Ph.D. \\ Alan J. Sexstone, Ph.D. \\ Mark Sperow Ph.D.
}

Division of Plant and Soil Science

Morgantown, West Virginia

2011

Keywords: Reclaimed minesoils, Soil Organic Carbon Sequestration,

Coal, Spectroscopy, Molecular Properties, Degree of Humification, Aromaticity, Stable Carbon 


\title{
ABSTRACT \\ Temporal Changes in Soil Carbon Concentration and Quality in a Reclaimed Minesoil Chronosequence
}

\author{
Sriroop Chaudhuri
}

Atmospheric carbon dioxide $\left(\mathrm{CO}_{2}\right)$ concentrations have increased significantly over the last half century causing erratic changes in global climate and the ecological balance of the earth. With proper land management practices, reclaimed minesoils can act as $\mathrm{CO}_{2}$ sinks, thus contributing to the terrestrial carbon sequestration efforts to mitigate effects of increased atmospheric $\mathrm{CO}_{2}$ concentrations. The objective of this research was to determine temporal changes in soil organic carbon (SOC) geochemistry and contents in a reclaimed minesoil chronosequence. The study area comprised four reclaimed minesoils in Monongalia County, West Virginia, with time since reclamation ranging between 2 to 21 years. A comparison between reclaimed minesoils and hayfield soils to determine minimum samples size requirements based on landuse showed that average SOC $\left(\mathrm{g} \mathrm{kg}^{-1}\right)$ and SOC stock ( $\mathrm{Mg} \mathrm{C}^{-1}$ ) were larger in the hay fields $\left(40 \mathrm{~g} \mathrm{~kg}^{-1} ; 29 \mathrm{Mg} \mathrm{Cha}^{-1}\right)$ than the reclaimed minesoils $\left(20 \mathrm{~g} \mathrm{~kg}^{-1} ; 20 \mathrm{Mg} \mathrm{C} \mathrm{ha}^{-1}\right)$. Average soil bulk densities $\left(\rho_{\mathrm{b}}\right)$ were significantly larger in reclaimed minesoils $\left(1.4 \mathrm{~g} \mathrm{~cm}^{-3}\right)$ than in hay field soils $\left(1.2 \mathrm{~g} \mathrm{~cm}^{-3}\right)$. The $\rho_{\mathrm{b}}$ variability was significantly larger in minesoils than the hayfield soils while SOC $\left(\mathrm{g} \mathrm{kg}^{-1}\right)$ and SOC stock $\left(\mathrm{Mg} \mathrm{C} \mathrm{ha}^{-1}\right)$ variabilities were not related to landuse. The minimum number of samples required to characterize $\rho_{\mathrm{b}}$, SOC, and SOC stocks was a site-specific property and could not be assumed a priori based on disturbance and/or landuse history. The oldest minesoil had larger SOC $\left(21.7 \mathrm{~g} \mathrm{~kg}^{-1}\right.$ vs $\left.11 \mathrm{~g} \mathrm{~kg}^{-1}\right)$ and SOC stocks (11.7 $\mathrm{Mg} \mathrm{Cha}^{-1}$ vs $4.2 \mathrm{Mg} \mathrm{C} \mathrm{ha}^{-1}$ ) indicating positive effects of increasing time since reclamation on SOC sequestration along the chronosequence. Soil bulk density was larger in the youngest minesoil $\left(>1.45 \mathrm{~g} \mathrm{~cm}^{-3}\right)$ suggesting effects of recent compressive reclamation techniques. Soil $\mathrm{pH}$ ranged between 6.7 and 7.5 and was similar across the chronosequence. Electrical conductivity was larger in the youngest minesoil. The largest clay contents were found in the youngest minesoil. Soil cation exchange capacity (CEC) 
was significantly larger in the oldest $\left(12 \mathrm{cmol}_{\mathrm{c}} \mathrm{kg}^{-1}\right)$ than the youngest $\left(3 \mathrm{cmol}_{\mathrm{c}} \mathrm{kg}^{-1}\right)$ minesoil. Soil CEC in older minesoils was influenced more by SOC than by clay, while the opposite was observed in younger minesoils. The relationship of SOC stock to time since reclamation was best described by a logarithmic, diminishing returns model. When taken as the first derivative of the diminishing returns model, long-term SOC sequestration rates were shown to decline precipitously $(80 \%)$ in the first five years after reclamation. The model predicts that minesoil surface horizons will contain about 13.3 $\mathrm{Mg} \mathrm{SOC} \mathrm{ha}{ }^{-1}$ at $50 \mathrm{yr}$ after reclamation. About $75 \%$ of that SOC storage is predicted to be achieved in the first decade after reclamation. In each minesoil the SOC was made of a labile and a resistant fraction with the latter being more humified than its labile counterparts. The SOC molecular characteristics changed rapidly in the initial (younger minesoils) post reclamation phases and then leveled off (older minesoils), indicating that SOC molecular configurations had become more stable with increasing time since reclamation. Stronger relationships between SOC $\left(\mathrm{g} \mathrm{kg}^{-1}\right)$ and several spectroscopic indices were found in the older minesoils. The overall SOC dynamics were controlled mostly by the molecular characteristics of the resistant SOC fractions in each minesoil. In a sequential chemi-thermal extraction to isolate coal-C and several SOC pools we found that SOC was about $20 \mathrm{~g} \mathrm{~kg}^{-1}$ and $8 \mathrm{~g} \mathrm{~kg}^{-1}$ in the oldest and the youngest minesoil, respectively. The resistant humin fraction constituted the bulk of SOC in the oldest minesoil while a labile acid-hydrolysable SOC fraction was the dominant SOC fraction in the youngest minesoils. Coal- $\mathrm{C}$ was similar in all the minesoils ranging from about 0.60 to $1.50 \mathrm{~g} \mathrm{~kg}^{-1}$ and was less than $15 \%$ of the total soil carbon (TSC). Overall, we found distinct relationships between various soil C pools and TSC, influenced by time since reclamation. A stronger positive relationship was observed between the stable humin fraction and TSC in the older minesoils while the TSC of the younger minesoils were more influenced by the labile soil carbon (SC) fractions. 


\section{ACKNOWLEDGEMENTS}

I would like the opportunity to thank some people without whose support, the successful completion of this research would not have been possible at all.

A very special thanks goes to my advisor Dr. Louis McDonald, without whose support, patience and intellect none of this would have been possible. His cooperation, expertise, and assistance throughout the entire span of my doctoral study at WVU have helped me immensely in achieving my goals. I would also like to thank my other committee members, Dr. Eugenia-Pena Yewtukhiw, Dr. Jeffrey Skousen, Dr. Alan Sexstone, and Dr. Mark Sperow for their thoughtful input and cooperation in this research.

This dissertation is dedicated to my soul mate Mimi, the best wife and friend one can ever dream of. Thank you so much for all the support, patience and encouragement that you have shown over these years.

I want to take this opportunity to thank my Ma and Baba, though far away geographically but been so close to heart always, without whose help, blessings, guidance and encouragement none of this would have been possible. 


\section{TABLE OF CONTENTS}

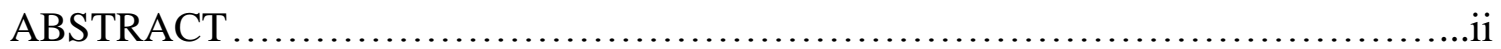

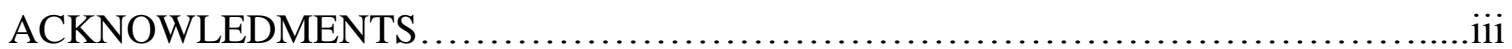

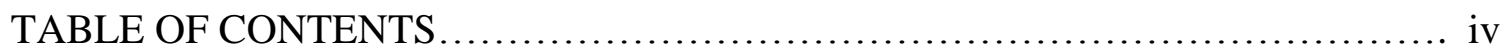

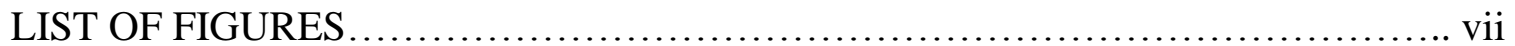

LIST OF TABLES ............................................................ vii

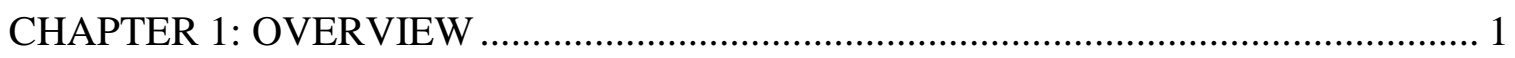

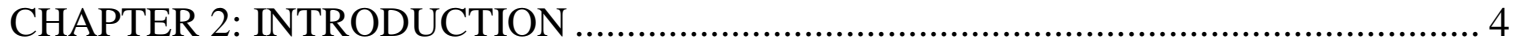

CHAPTER 3:Land Use Effects on Sample Size Requirements for Soil Organic

Carbon Stock Estimations ................................................................. 22

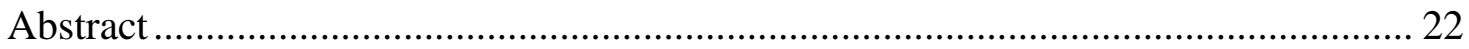

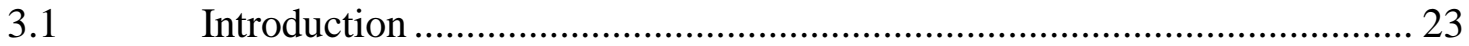

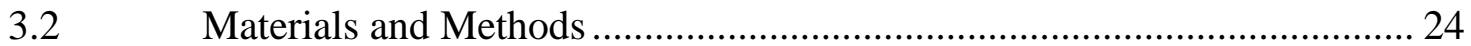

3.2.1 Sample Collection and Preparation ........................................................ 25

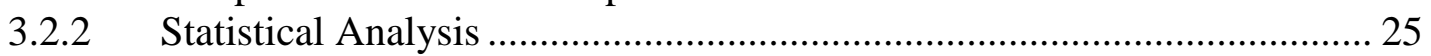

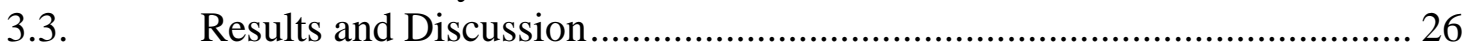

3.3.1 Soil bulk density and soil organic carbon characterization....................... 26

3.3.2 Sample number requirement …………………................................ 27

3.3.3 Point-based versus mean-based SOC stock estimates............................... 27

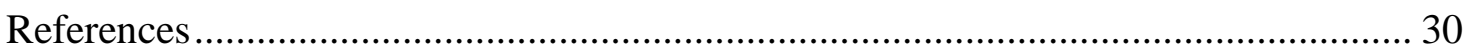

CHAPTER 4: Temporal Dynamics in Minesoil Surface Carbon Sequestration Due to

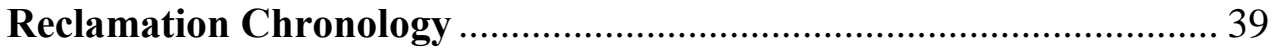

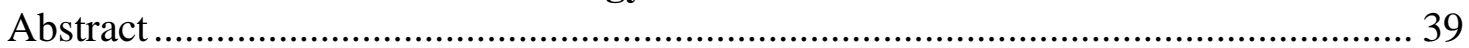

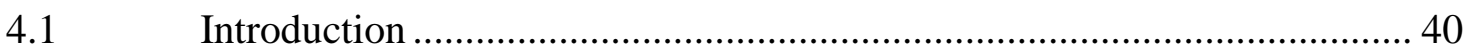

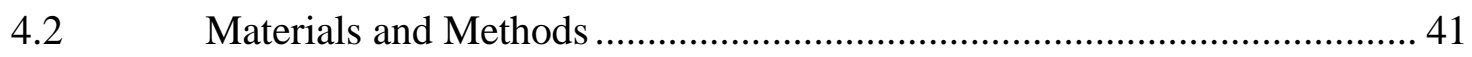

4.2.1 Site Description ............................................................................. 41

4.2.2 Minesoil Sampling and Analysis........................................................... 42

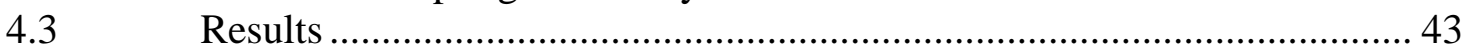

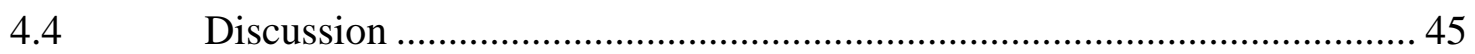

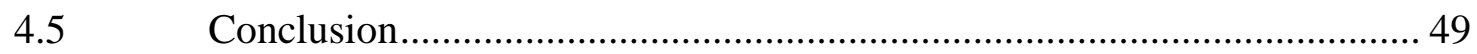

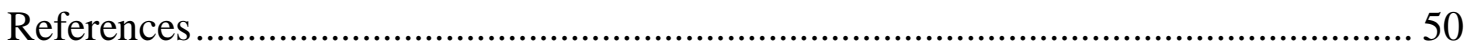

CHAPTER 5:Molecular Properties of Soil Organic Carbon (SOC): Indicators of SOC Sequestration in a Reclaimed Minesoil Chronosequence............. 65

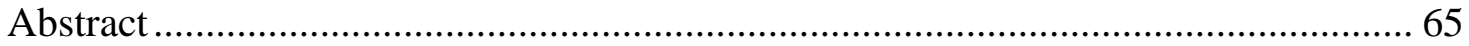

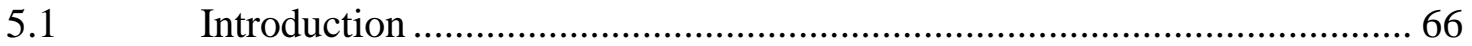

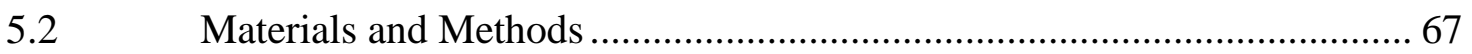

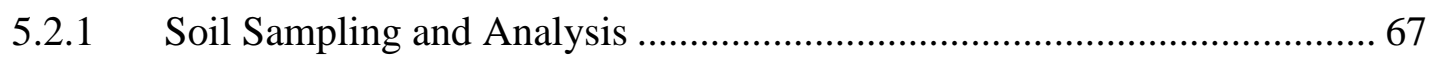

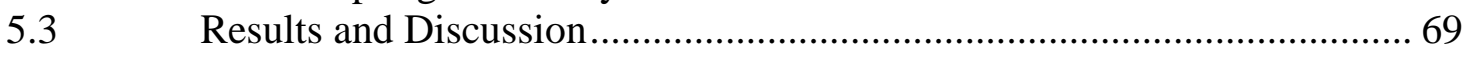

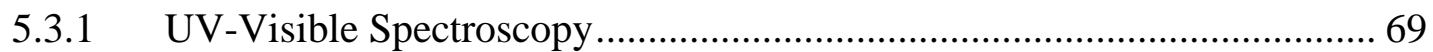

5.3.2 Fluorescence Spectroscopy ………………………………………….... 70 


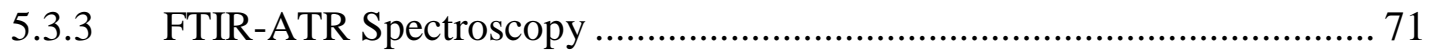

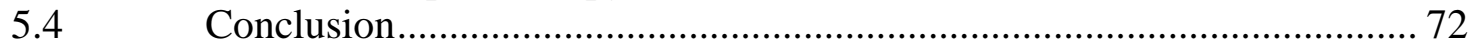

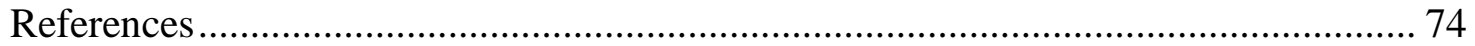

CHAPTER 6: Characterization of Different Soil Carbon Pools and Coal Carbon in a Reclaimed Minesoil Chronosequence................................................. 89

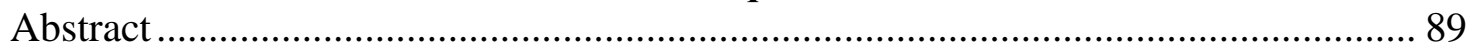

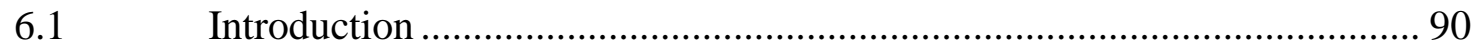

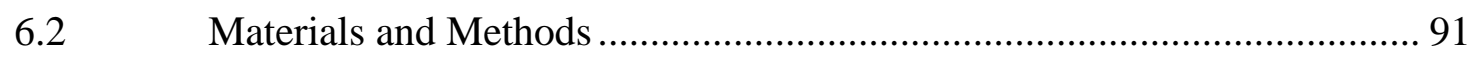

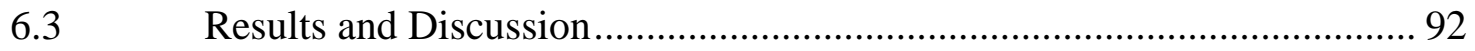

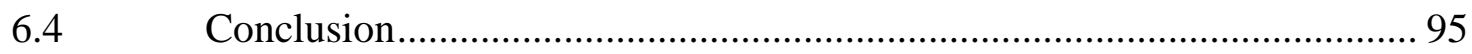

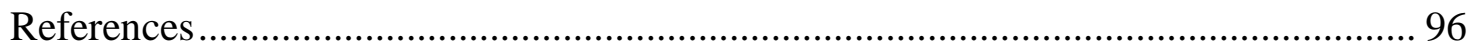

CHAPTER 7: Conclusion............................................................................................ 108 


\section{LIST OF FIGURES}

Figure 3-1: Sample size $\left(\hat{\mathrm{n}}^{0.5}\right)$ required to determine (a) soil bulk density $(\mathrm{g} \mathrm{cm}-3)$, (b) SOC $(\mathrm{g} / \mathrm{kg})$, and (c) SOC stock $\left(\mathrm{Mg} \mathrm{C} \mathrm{ha}^{-1}\right)$ for selected absolute deviations (L); plotted using Equation 3. Range on y-axis is 4 to 196 samples.

Figure 3-2: Plotted residuals as response factor to the fitted value (Eq. 2) for (a) WVO1, and (b) Mylan Park.

Figure 3-3: Plotted residuals as response factor to the fitted value (Eq. 2) for (a) Pasture 1 , and (b) Pasture 2.

Figure 4-1: The relationship between SOC stock and time since reclamation for the minesoil chronosequence.

Figure 4-2: The relationship between the rate of SOC sequestration and the time since reclamation for the minesoil chronosequence. The relationship shown is the first derivative of the relationship shown in Figure 4-1. The time since reclamation is plotted for each of the six site-sampling events.

Figure 5-1: Relationship between UV-Visible and fluorescence spectroscopic indices with time since reclamation across the chronosequence for the labile and resistant SOC fractions at each minesite.

Figure 5-2: Ternary diagram illustrating locations of the reclaimed minesoils with respect to total SOC (\%) and the indices for the (a) resistant and (b) labile SOC fraction for 2008 sampling event.

Figure 5-3: (a) FTIR-ATR spectra and (b) comparison of relative absorbances for specific absorption bands for each reclaimed minesoil.

Figure 6-1: Sequential extraction scheme to isolate soil carbon (SC) pools and coal-C $(\mathrm{BHSC}=$ Base-hydrolysable soil carbon, $\mathrm{AHSC}=$ Acid-hydrolysable soil carbon, HFHSC $=10 \%$ HF-hydrolysable soil carbon, FBHSC $=$ Final basehydrolysable soil carbon)

Figure 6-2: Percentages of various soil carbon pools in TSOC at (a) Mylan Park, (b) New Hill. (c) SK and (d) WVO1. 101 


\section{LIST OF TABLES}

Table 2-1: Major problems related soil quality parameters in reclaimed minesoils (modified from Shrestha and Lal, 2006).

Table 3-1: Summary statistics for SOC, $\rho b$, and SOC stock at each reclaimed mine site (MP and WV01) and each managed hay field site (HF1 and HF2).

Table 3-2: Minimum number of samples required ( $\hat{n}$ ) to detect a $10 \%$ change (from the mean) in SOC, $\rho b$, and SOC stock values at the 90, 95 and $99 \%$ levels of confidence ( $\alpha=0.10,0.05$ and 0.01 , respectively)

Table 3-3: Regression parameters obtained for the straight line relationship between the mean-based ( $\left.\mathrm{Mg} \mathrm{C}_{\mathrm{mb}} \mathrm{ha}^{-1}\right)$ and point-based $\left(\mathrm{Mg} \mathrm{C}_{\mathrm{pb}} \mathrm{ha}^{-1}\right)$ SOC stock values and the statistical significance difference from the 1:1 line (mean-based versus point-based SOC stock values) ............................................................... 38

Table 4-1. Characteristics of the reclaimed minesoil sites included in the study............ 56

Table 4-2: Grid dimensions and number of minesoil samples collected, by site. 57

Table 4-3: Descriptive statistics for the minesoil bulk densities (BD) found in 2007 and 2008.

Table 4-4: Descriptive statistics for the SOC concentrations $\left(\mathrm{kg} \mathrm{Mg}^{-1}\right)$ found in 2007 and 2008.

Table 4-5: Descriptive statistics for the SOC stocks found in 2007 and 2008. 60

Table 4-6: Descriptive statistics for the minesoil particle size fractions (texture) found in 2008.

Table 4-7: Descriptive statistic for selected minesoil properties found in 2008

Table 4-8: Simple linear correlation coefficient (Pearson's r) between measured soil variables, for the 2008 sampling event.

Table 4-9: Cation exchange capacity $\left(\mathrm{cmol}_{\mathrm{c}} \mathrm{kg}^{-1}\right)$ regression prediction models based on clay $(\%)$ and SOC $(\mathrm{g} / \mathrm{kg})$ for 2008 sampling event.

Table 5-1: General characteristics of the reclaimed minesites included in the study.

Table 5-2: Description of UV-Vis and synchronous fluorescence spectroscopic indices used in the study (A: Absorption; F: Fluorescence maxima; DOC: Dissolved Organic Carbon). 
Table 5-3a: Summary statistics of UV-Visible indices for the resistant SOC fraction for 2007 and 2008 sampling events

Table 5-3b: Summary statistics of UV-Visible indices for the labile SOC fraction for 2007 and 2008 sampling events

Table 5-4a: Summary statistics of synchronous fluorescence indices for the resistant SOC fraction for 2007 and 2008 sampling events ................................................. 85

Table 5-4b: Summary statistics of synchronous fluorescence indices for the labile SOC fraction for 2007 and 2008 sampling events ................................................. 86

Table 5-5: Correlation coefficients for different spectroscopic indices in the minesoils for both years for the resistant SOC fractions.

Table 5-6: Correlation coefficients for different spectroscopic indices in the minesoils for both years for the labile SOC fractions......................................................... 88

Table 6-1: General characteristics of the reclaimed minesites included in the study ..... 102

Table 6-2: Descriptive statistics for total soil carbon (TSC, $\mathrm{g} \mathrm{kg}^{-1}$ ) and total soil organic carbon (TSOC, $\mathrm{g} \mathrm{kg}^{-1}$ ) along the reclaimed minesoil chronosequence ........ 103

Table 6-3: Descriptive statistics of various SC pools $\left(\mathrm{g} \mathrm{kg}^{-1}\right)$ isolated by the sequential extraction procedure 104

Table 6-4: Descriptive statistics for coal- $\mathrm{C}\left(\mathrm{g} \mathrm{kg}^{-1}\right)$ along the minesoil chronosequence

Table 6-5: Descriptive statistics for total recovery (\%) for reclaimed minesoil............. 106

Table 6-6: Regression coefficients $\left(\mathrm{R}^{2}\right)$ between TSC and SC pools including coal-C. 107 
Carbon dioxide $\left(\mathrm{CO}_{2}\right)$ concentrations in the atmosphere, due to miscellaneous anthropogenic activities, have been estimated to increase from 7.4 Gigatons $\mathrm{Gt} \mathrm{C} \mathrm{yr}^{-1}(1 \mathrm{Gt}=$ $10^{15} \mathrm{~g}$ ) in 1997 up to about $26 \mathrm{Gt} \mathrm{C} \mathrm{yr}^{-1}$ by 2100 (Houghton, 1995). Since 1800, the average global $\mathrm{CO}_{2}$-concentration has risen from 280 ppmv to about $378 \mathrm{ppmv}$ in 2005, a $35 \%$ increase (Shrestha and Lal, 2006). The $\mathrm{CO}_{2}$-accumulation in the atmosphere could result in erratic changes in global climate which in turn would affect the overall ecological balance of the earth. Projected climate change, due to accumulation of atmospheric $\mathrm{CO}_{2}$, has propelled diverse research initiatives to design long-term ameliorative strategies to remove atmospheric $\mathrm{CO}_{2}$.

Terrestrial carbon sequestration has a potential role in reducing the recent increase in atmospheric- $\mathrm{CO}_{2}$. Soils can sequester atmospheric $\mathrm{CO}_{2}$ and contribute significantly to terrestrial carbon sequestration efforts (Paul et al., 1997; Lal and Bruce, 1999; Rosenzweig and Hillel, 2000). Soil is a major $\mathrm{CO}_{2}$-sink, containing twice as much $\mathrm{C}$ as the atmosphere and nearly three times that within standing vegetation (Schlesinger, 1991). It is, however, this pool that is most vulnerable to disturbances. However, practices and management efforts that retain SOC lead to C sequestration and can reduce greenhouse effects (Schlamadinger and Marland, 2000).

Soil carbon sequestration is the process of incorporation of atmospheric- $\mathrm{CO}_{2}$ into the soil via root turnover, litter decomposition and various soil-biological processes. Development of the soil organic carbon (SOC) pool is desirable in agro-ecosystems for its beneficial role in nutrient cycling, water holding capacity, aggregation, air-water movements, root development, and microbial activity.

Land management practices significantly influence SOC sequestration processes (Puget and Lal, 2005; Kasper et al., 2006; Woodbury et al., 2006). Several studies have reported SOC sequestration processes in undisturbed soils (Collins et al., 2000). In the Appalachian region surface coal mining is a major landuse practice which heavily influences pedospheric processes. Surface mining disturbs the soil profile and alters soil physical and structural properties. Constructed or reclaimed minesoils exhibit soil conditions drastically altered by anthropogenic perturbations rather than natural soil forming processes (Shukla et al., 2004a, b). Restoration of disturbed minesoils can improve soil quality, biomass productivity, SOC concentration, and C 
sequestration potentials (Lal et al., 1998; Shukla et al., 2004b). Reclaimed minesoils can sequester significant amounts of $\mathrm{C}$ with adoption of appropriate land management strategies and time since reclamation (Shukla et al., 2005). Two-fold increase in SOC was reported for some reclaimed minesoils in Ohio, 20 years after topsoil application (Akala and Lal, 2001a, b; Shukla et al. 2004b).

Major problems in accurate determination of SOC sequestration are accounting for the intense variability in minesoil properties arising from mining and reclamation operations and distinguishing between geogenic $\mathrm{C}$ (coal-C) mixed with pedogenic- $\mathrm{C}$ (SOC). Only pedogenic $\mathrm{C}$ can reduce atmospheric $\mathrm{CO}_{2}$ concentrations. Estimates of SOC stocks have often been made using an average bulk density and a composite SOC concentration (Jacinthe et al., 2007). This, however, leads to questions of accuracy and statistical power. On the other hand, methods to separate Coal-C from SOC are still under review and most are subject to significant error.

The overall goal of this research was to determine SOC sequestration in a chronosequence of reclaimed minesoils with different time since reclamation but similar topography, bedrock geology, vegetation and climatic conditions. The research was divided into four objectives as follows:

1. Determine the minimum number of samples required to characterize SOC sequestration. We compared results between reclaimed minesoils and hay field soils to understand how disturbance affected variability SOC (\%), bulk density and SOC stocks ( $\left.\mathrm{Mg} \mathrm{C} \mathrm{ha}^{-1}\right)$ and thus SOC sequestration.

2. Determine the SOC sequestration along a reclaimed minesoil chronosequence and assess the interrelationships between SOC and the soil quality parameters soil bulk density, cation exchange capacity, electrical conductivity, $\mathrm{pH}$ and texture.

3. Determine overall SOC molecular characteristics and how they change along the minesoil chronosequence. The main purpose was to gain some insight into the compositional and structural characteristics of SOC that leads to SOC stabilization and C-sequestration over time and to assess if SOC molecular characteristics are useful for distinguishing between minesoils developed over different periods of time. 
4. Assess the efficiency of a sequential chemi-thermal extraction scheme to distinguish between Coal-C and SOC and to estimate proportions of various SOC pools in minesoils. The purpose was to assess effects of time since reclamation on the recalcitrant SOC fractions in each minesoil and relate them to overall SOC sequestration along the minesoil chronosequence. 
Mining operations destroy the natural landscapes and adversely affect soil quality, leading to soil acidity, nutrient deficiency, lack of soil structure, reduced water holding capacity, low soil organic matter contents and microbial activities (Table 1) (Johnson and Skousen, 1995; Shukla et al., 2004a, b; Lal and Ussiri, 2005).

Table 2-1: Major problems related soil quality parameters in reclaimed minesoils (modified from Shrestha and Lal, 2006).

\begin{tabular}{llll}
\hline Aspect & Variable & Problem & Management Schemes to Mitigate \\
\hline Physical & Soil Structure & Compaction & $\begin{array}{l}\text { Growing suitable vegetative coverings } \\
\text { Regradation or growing suitable vegetative } \\
\text { coverings }\end{array}$ \\
& Moisture & Too dry & Growing tolerant species \\
Nutritional & Macronutrients & N-deficiency & $\begin{array}{l}\text { Growing leguminous trees or shrubs (N- } \\
\text { fixers })\end{array}$ \\
& Micronutrients & Application of organic manures \\
Toxicity & pH & Too high & $\begin{array}{l}\text { Natural weathering or growing tolerant } \\
\text { species }\end{array}$ \\
& Heavy metals & Too high & $\begin{array}{l}\text { Application of organic matter or growing } \\
\text { tolerant cultivars }\end{array}$ \\
& Salinity & Too high & $\begin{array}{l}\text { Application of gypsum, Improved irrigation } \\
\text { system, Natural weathering or Growing } \\
\text { tolerant species }\end{array}$ \\
& & &
\end{tabular}

However, it has been demonstrated that reclaimed minesoils can sequester significant amounts of atmospheric $\mathrm{CO}_{2}$ leading to improvements in soil properties (Akala and Lal, 2001a; IPPC, 2000; Thomas et al., 2000). The potential for SOC sequestration in reclaimed minesoils largely depends on biomass productivity, root network development in the subsoil horizons, stable soil structure development, aggregation, humification processes and changes in minesoil properties resulting from overburden weathering. In the United States, there are 3.2 Mha of 
minelands which are capable of sequestering $\mathrm{C}$ up to a rate of $0.5-1.0 \mathrm{MgC} \mathrm{ha}^{-1} \mathrm{yr}^{-1}$ through reclamation which in turn could incorporate 1.6-3.2 $\mathrm{Tg} \mathrm{C} \mathrm{yr}^{-1}$ into the soils $\left(1 \mathrm{Tg}=10^{12} \mathrm{~g}\right)$, counterbalancing some of the 5.8-11.2 $\mathrm{Tg} \mathrm{CO}_{2} \mathrm{yr}^{-1}$ emerging from the burning of coal (Lal, 2004). Since the carbon content of reclaimed minesoils is comparatively low compared to undisturbed soils, the ability of reclaimed minesoils to sequester $\mathrm{C}$ could be significant (Bussler et al., 1984; IPPC, 2000). One estimate showed that in the United States, with a rate of 25 to 35 $\mathrm{Mg} \mathrm{C} \mathrm{ha}{ }^{-1} \mathrm{yr}^{-1}$, there was a potential to sequester 45 to $63 \mathrm{Tg}$ of carbon over a 20-30 year period (Akala and Lal, 2001b).

Time since reclamation plays a major role in developing soil properties and SOC pools in reclaimed minesoils. Research on SOC sequestration in reclaimed minesoils has mainly involved chronosequence-based approaches. Soils developing over different time periods but under similar conditions of topography, vegetation, climate and parent materials are genetically related, forming a soil chronosequence (Harden, 1982). Soil chronosequence studies yield information about the rate and direction of pedological changes and these soils are valuable tools in soilgeomorphic research (Pillans et al., 1997; Hugget, 1998). In several chronosequence studies it has been found that with time, reclaimed minesoils attain comparable soil qualities to that of undisturbed soils (Akala and Lal, 2001a; Shukla et al., 2005). After 100 years of soil formation on loess-derived spoils in Iowa, the SOC stock in the upper 10 and $50 \mathrm{~cm}$ were about 26 and 82 $\mathrm{Mg} \mathrm{C} \mathrm{ha}^{-1}$ (Hallberg et al. 1978). In some sandy minespoils in southern Saskatchewan, between 30 to 40 years, SOC stocks increased by 0.5 and $1.4 \mathrm{Mg} \mathrm{ha}^{-1} \mathrm{yr}^{-1}$ in the upper 10 and $100 \mathrm{~cm}$ (Anderson, 1977). In 15 minesoils in Montana the SOC content in the 0-10 cm returned to premining levels within 30 years of reclamation, (Schafer et al., 1980). In a chronosequence comprising six coal mine spoils in Illinois SOC stocks increased by 0.1 and $0.3 \mathrm{Mg} \mathrm{ha}^{-1} \mathrm{yr}^{-1}$ in the upper $10 \mathrm{~cm}$ and $50 \mathrm{~cm}$ (Thomas and Jansen, 1985).

Reclaiming minesoils with pasture/forest ecosystems, implementation of crop rotation techniques combined with fertilization, manuring etc. in Ohio have proven to be suitable for mineland restoration (Akala and Lal, 2001a; Shukla and Lal, 2005; Ussiri et al., 2006). In a chronosequence in Ohio, the SOC stocks at the reclaimed pasture site increased from about 15 to $44 \mathrm{Mg} \mathrm{ha}^{-1}$ and from about 11 to $18 \mathrm{Mg} \mathrm{ha}^{-1}$ for $0-15 \mathrm{~cm}$ and $15-30 \mathrm{~cm}$ depth respectively while at the reclaimed forest site SOC stocks increased from 12 to $45 \mathrm{Mg} \mathrm{ha}^{-1}$ and from 91 to $136 \mathrm{Mg}$ 
$\mathrm{ha}^{-1}$ for $0-15 \mathrm{~cm}$ and $15-30 \mathrm{~cm}$ depth intervals respectively with 25 years of soil development (Akala and Lal, 2001b).

Other studies have demonstrated the beneficial effects of fertilizers and various amendments on the restoration of disturbed soils (Zvomuya et al., 2007). In a reclaimed minesoil chronosequence in Ohio, the SOC stocks increased twofold within 20 years of reclamation in the upper horizons with comparable soil conditions between minesoils and undisturbed soils with NPK-fertilization (Shukla et al., 2004a). Significant positive effects of P-fertilizers along with various topsoiling techniques were observed in a 15-year old reclaimed minesoil in southern Ohio with significant accumulation of 'labile' SOC pool in the upper 0-10 cm (Jacinthe and Lal, 2007). Effects of sawdust and municipal sewage sludges on soil organic matter (SOM) dynamics over 16 year period in a reclaimed minesoil showed that SOM- and nitrogen-mineralization trends were comparable to various undisturbed soils with the most significant 'improvement' being noticed in the initial 5 years (Bendfeldt et al., 2001). Productivity of several reclaimed minesoils was found comparable to undisturbed soils in Midwestern coalfields (Rodrigue and Burger, 2004). Reclaimed forest soils had SOC contents to comparable undisturbed forests and about $49 \%$ higher than agricultural soils after 28-years of reclamation (Shrestha and Lal, 2008).

However, reclamation done according to the guidelines of the federal Surface Mining Control and Reclamation Act (SMCRA, 1977) often leads to difficulties in determining SOC sequestration. The guidelines require surface minelands to be topsoiled, amendmened and fertilized to sustain biological activity (Shukla et al., 2004a,b). In addition SMCRA also requires that backfilling by overburden materials and compaction to match the regional contour (Jacinthe and Lal, 2007). A limitation of this approach is the significant loss of SOC resulting from topsoil removal and storage operations (Abdul-Kareem and McRae, 1984). The use of heavy machinery and topsoil replacement results in variable degrees of soil compaction. The mixing of dissimilar materials at random combined with the lack of biological activity, lack of soil structure and postreclamation land use practices results in high variability in soil properties (Gerke et al., 2001; Shukla et al., 2005, 2007; Hangen et al., 2004, 2005; Nyamadzawo et al., 2007). However, contradictory views exist regarding the relationship between soil spatial variability and time since reclamation. 
In one chronosequence study it was found that inorganic $\mathrm{N}$ and organic $\mathrm{C}$ were spatially dependent, with spatial variability decreasing significantly with time (Boerner et al., 1998). In another study lower variability in several minesoil properties, including SOC concentrations, were observed initially after reclamation and increased as minesoils aged (Shukla et al., 2007). In a similar study, spatial structures of soil properties were found independent of time since reclamation (Nyamadzawo et al., 2007). Twenty years after reclamation, certain microbial properties and inorganic $\mathrm{N}$ showed spatial dependency whereas SOM did not (Mummy et al., 2002). In general, considerable variability exists in reclaimed minesoil properties due to mining and reclamation processes and due to different time intervals over which these soils form.

Soil organic carbon sequestration results from SOC-stabilization and accumulation of this stable fraction. In general, three mechanisms have been put forward to describe SOC stabilization: (i) physical preservation in which SOC is partitioned into soil aggregates thus becoming inaccessible to microbial enzymes (Six et al., 2004, Jastrow, 1996), (ii) chemical preservation in which SOC binds with the mineral matrix to form organo-mineral complexes (Kaiser et al., 2002; Guggenberger and Kaiser, 2003; Mikutta et al., 2006;) and (iii) by inherent biochemical recalcitrance (Poirier et al., 2003; Tan et al., 2004). Based on turnover rates, SOC has been divided into three pools, a labile pool essentially made up of root exudates and fresh plant litter having a turnover times of less than a year; a recalcitrant pool consisting of stabilized SOM that persists over millennia; and a poorly defined intermediate pool with turnover period between several years to centuries (Brunn et al., 2005). A variety of geochemical techniques have been used to isolate these SOC pool. Examples include sequential hydrolysis with trifluoroacetic acid (TFA) followed by $6 \mathrm{~N} \mathrm{HCl}$ (Quenea et al., 2005, Helfrich et. al., 2007), single step 6N HCl-extraction (Plante et al., 2006, Paul et al. 2006), oxidative removal of SOC with $\mathrm{H}_{2} \mathrm{O}_{2}$ (Plante et al., 2004), disodium peroxodisulphate $\left(\mathrm{Na}_{2} \mathrm{~S}_{2} \mathrm{O}_{8}\right)$ (Eusterhues et al., 2003), or $6 \%(\mathrm{w} / \mathrm{w})$ sodium hypochlorite $(\mathrm{NaOCl})$ at $\mathrm{pH} 8$ (Helfrich et al., 2007), and demineralization with 10\% hydrofluoric acid (HF) to release mineral-bound SOC (Eusterhues et al., 2007; Helfrich et al., 2007). Soil organic carbon pools isolated by $\mathrm{H}_{2} \mathrm{O}_{2}, \mathrm{Na}_{2} \mathrm{~S}_{2} \mathrm{O}_{8}$, or $\mathrm{NaOCl}$ have been used most frequently to isolate a stable and older SOC pool (Helfrich et al., 2007; Mikutta et al., 2006). Numerous studies have reported the efficiencies of these methods to isolate stable SOC pools (Helfrich et al., 2007; Zimmerman et al., 2007). In a reclaimed minesoil chronosequence in southeastern Ohio, oxidation followed by demineralization was able to isolate a stable SOC pool 
that was significantly larger in older than younger minesoils. This indicated that the proportion of stable SOC increases with time since reclamation. Radiocarbon analyses revealed HF-resistant SOC-fractions represented stable and older SOC in agricultural and forest soils (Eusterhues et al., 2003, Kaiser et al., 2002). Acid-hydrolysis removed labile SOC, mainly proteins, nucleic acids, fatty acids and polysaccharides causing the acid-resistant nonhydrolyzable carbon fraction (NHC) to be enriched in long-chain alkyls, waxes, lignin, and various aromatics (Ostle et al., 1999; Paul et al., 2000). Studies have shown that the NHC fraction represents from 30 to $65 \%$ of the total SOC in agricultural soils in Midwestern United States and is about 1300-1800 years old (Leavitt et al., 1996; Paul et al., 1997). Coupled with ${ }^{14} \mathrm{C}$-dating, acid hydrolysis has been implemented to investigate dynamics of SOC in the estimation of size and turnover rate of the stable SOC pool in various models (Leavitt et al., 1996; Falloon et al., 1998; Paul et al., 2000).

One of the major difficulties in determining accurate SOC sequestration patterns in reclaimed minesoils is to distinguish geogenic-C (coal-C) from pedogenic-C (SOC) (Ussiri and Lal, 2008).Therefore, accurate determination of coal-C in reclaimed minesoils is essential to understand SOC dynamics in these disturbed lands and their relative contribution to the terrestrial carbon sequestration. However, attempts to quantify coal-C in reclaimed minesoils have been scant. Stable isotope $\left(\delta^{13} \mathrm{C}\right)$ measurements (Ussiri and Lal, 2008) and radiocarbon $\left({ }^{14} \mathrm{C}\right)$ methods (Rumpel et al., 1988; Chabbi et al., 2007; Ussiri and Lal, 2008) have often been used to distinguish between "recent" or plant-derived and "old" or coal-derived carbon based on their age of formation. Thermogravimetric and derivative thermogravimetric (TG/DTG) techniques have been developed as potential methods to differentiate organic, inorganic and coal-derived carbon in soil materials. In these techniques, soil materials are heated within a range of temperature by gradual increments. Based on mass loss within definite temperature intervals carbon types are characterized. Thermogravimetric methods have been used to identify coal, tar, limestone, litter and other charred residual materials in soils (Siewert, 2004; Maharaj et al., 2007a, b). However, radiocarbon, stable isotope and TG/DTG methods are expensive and require significant resources, expertise in sample preparation, data handling and interpretation of the results. Thermal oxidation coupled with ${ }^{13} \mathrm{C}$ NMR spectroscopic methods has also been useful in isolating a stable "black carbon" in from sediments and soils (Haumaier and Zech, 1995; Gelinas et al., 2001, Simpson and Hatcher, 2004). An alternative method has been proposed by Ussiri and Lal, (2008) which uses a combination of geochemical and thermal oxidation processes to 
characterize coal-C. This method also distinguishes between different SOC fractions such as oxidisable, mineral-bound and humin, thus providing insights into the overall SOC dynamics and C-sequestration processes.

Knowledge of the structure and composition of SOC molecules can offer important clues for understanding of SOC quality and therefore potential for SOC sequestration. Spectroscopic techniques are nondestructive, easy-to-use methods to gain insight into the overall molecular composition and structure of SOC. Absorption of ultra violet (UV) light below wavelength of $400 \mathrm{~nm}$ results from the presence of various aromatic groups with variable degrees of substitution including mono- and poly-substituted phenols (Khorsin et al., 1997). Absorption of UV light in 200-380 $\mathrm{nm}$ range is indicative of conjugated systems, as commonly associated with aromatic moieties (Weishaar et al., 2003). Several UV-Visible absorption wavelengths have been used as indicators of SOC molecular characteristics (Hautala et al., 2000). Numerous studies have shown that ratios calculated by UV-Visible absorption bands can be used to characterize dissolved organic carbon contents (Deflandre and Gagne, 2001; Barreto et al., 2003), types of functional groups (Khorosin et al., 1997; Abbt-Braun and Frimmel, 1999; Barreto et al., 2003), degree of aromaticity (Kononova, 1966; Chin et al., 1994; Peuravori and Pihlaja, 1997; Oliviera et al., 2006), humification processes (Kukkonen, 1992; Volk et al., 2004), and effects of composting (Chanyasak et al., 1982; Rivero et al., 2004) of SOC molecules.

There are two fundamental types of molecular structures responsible for generating fluorescent behavior in organic molecules: (i) polycondensed aromatic and conjugated structures with high content of carboxylic groups and (ii) aromatic proteins such as tryptophan and tyrosine (Baker, 2002). Fluorescence intensities also relate to molecular sizes with peaks at lower wavelengths $(\sim 300 \mathrm{~nm})$ resulting from smaller molecules whiles peaks at higher wavelengths $(\sim 380 \mathrm{~nm})$ indicating presence of larger molecules. Efficient fluorophores are typically characterized by highly substituted, condensed aromatic rings, and/or highly unsaturated aliphatic chains (Sensei et al., 1989; Baker, 2002). Electron-withdrawing functional groups such as carboxyl, carbonyl (having double bonds) in organic matter increases the wavelengths of excitation and emission and in turn cause the fluorescence intensity to shift to lower energy levels or longer wavelengths. Aromatic ring structures containing conjugated double bonds behave similarly. On the other hand, fluorescence peaks occurring at a shorter wavelength $(\sim 390$ 
$\mathrm{nm}$ ) indicate relatively simple and less-conjugated aromatic structures and presence of electrondonating substituents such as hydroxyl, methoxyl and amino groups.

Fluorescence spectroscopic techniques have been used in wide variety of applications such as determination of the degree of decomposition of dissolved organic matter (Hunt and Ohno, 2007), characterization and classification of dissolved organic matter occurring in diverse systems (Peuravuori et al., 2002; Burdige et al., 2004; Cilenti et al., 2005), effects of cropping practices on chemical nature and quality of organic matter (Canellas et al., 2004), sources of DOC (Westerhoff and Anning, 2001), influences of composting on soil organic matter quality (Rivero et al., 2004), characterization of humic substances in composted urban wastes (Valesco et al., 2004). Different regions of fluorescence spectra are diagnostic of the types and number of aromatic rings and their condensation/conjugation in organic carbon molecules (Giovanni et al., 1995; Peuravuori et al., 2002). Fluorescence peaks at higher wavelengths are the result of a high degree of conjugated double or triple bonds containing $\pi$-electrons which are capable of movement (fluorescence) between orbitals. Humification of SOC molecules is indicated by a shift in emission spectra from shorter to longer wavelengths (red shift) due to the presence of reactive functional groups such as $\mathrm{O}$ - and $\mathrm{N}$-containing groups, highly substituted aromatic nuclei and/or presence of conjugated unsaturated systems capable of a high degree of resonance (Sensei et al, 1989; Sensei et al., 1991; Miano and Sensei, 1992; Baker, 2002).

Several absorption features in the near infra-red region $\left(400-4000 \mathrm{~cm}^{-1}\right)$ have been used in to elucidate types and contents of various functional groups attached to SOM (Ellerbrock and Gerke, 2004; Solomon et al., 2005). Several FT-IR (Fourier Transform Infrared) studies have been used to characterize SOC molecules in processes such as changes in land management practices (Haberhaur et al., 2000; Haberhaur and Gerzabek, 1999), effects of fertilization on SOC (Ellerbrock et al., 1999a, b), SOC humification (Ding et al., 2002; Giglotti et al., 2003), degree of decomposition and mineralization (Spaccini et al., 2001), effects of composting on SOC (Hadjia and Spoljar, 1995; Smidt et al., 2002), and the characterization of natural organic matter (NOM) in wastewater treatment systems (Kim and Yu, 2005). In a study on two constructed soils (24-yr and 2-yr old) contaminated with coal-C in southern Brazil, SOC molecules had higher aromaticity, higher O-alkyl, methoxyl- and carboxyl-C contents and were more highly conjugated systems in the older soils than the younger soils. (Dick et al., 2006). 
Contamination by coal-C results in increasing refractory/recalcitrant nature of SOC with a concomitant increase in the aromatic-C and/or alkyl C content of SOM (Dick et al., 2006; Rumpel et al., 1998). Certain indices, devised by FT-IR absorption bands have been used to follow patterns of humification of SOM (Inbar et al., 1989; Canellas et al., 2004) based mainly on the relative proportions of polar vs. non-polar functional groups. 


\section{References}

Abbt-Braun, G. and F.H. Frinnel. 1999. Basic characterization of Norwegian NOM samplessimilarities and differences. Environ. Int. 25:161-180.

Abdul-Kareem, A.W. and S.G. McRae. 1984. The effects on topsoil of long-term storage in stockpiles. In Ingram, L.J., G.E. Schuman, P.D. Stahl, and L.K. Spackman. 2005. Microbial respiration and organic carbon indicate nutrient cycling recovery in reclaimed soils. Soil Sci. Soc. Am. J. 69:1737-1745.

Akala, V.A. and R. Lal. 2001a. Soil organic pools and sequestration rates in reclaimed minesoils in Ohio. J. Environ. Qual. 30:2090-2104.

Akala, V.A. and R. Lal. 2001b. Soil carbon enhancement in graded and ungraded reclaimed minesoil under forest and pasture in Ohio, USA. $10^{\text {th }}$ International Soil Conservation Organization Meeting, Purdue University and the USDA-ARS National Soil Erosion Research Laboratory.

Anderson, D.W. 1977. Early stages of soil formation on glacial till mine spoils in a semiarid climate. Geoderma 19:11-19.

Baker, A. 2002. Fluorescence properties of some farm wastes: Implications for water quality monitoring. Wat. Res. 36:189-195.

Barreto, S.R.G., J. Nozaki, and W.J. Barreto. 2003. Origin of dissolved organic carbon studied by UV-Vis spectroscopy. Acta. Hydrochim. Hydrobiol. 31:513-518.

Bendelfeldt, E.S., J.A. Burger, and W.E. Daniels. 2001. Quality of amended mine soils after 16 years. Soil Sci. Soc. Am. J. 65:1736-1744.

Boerner, R.E.J., A.J. Scherzer, and J.A. Brinkman. 1998. Spatial patterns of inorganic N, P variability, and organic $\mathrm{C}$ in relation to soil disturbance: A chronosequence analysis. Appl. Soil Ecol. 7:159-177.

Brunn, S., J. Six, L.S. Jensen, and K. Paustian. 2005. Estimating turnover of soil organic carbon fractions based on radiocarbon measurements. Radiocarbon. 47:99-113

Burdige, D.J., S.W. Kline, and W. Chen. 2004. Fluorescent dissolved organic matter in marine sediment pore waters. Marine Chem. 89:289-311.

Bussler, B.H., W.R. Byrnes, P.E. Pope, and W.R. Chaney. 1984. Properties of minesoil reclaimed for forest land use. Soil Sci. Soc. Am. J. 48:178-184. 
Canellas, L.P., J.A.A. Espindola, C.E. Rezende, P.B. de Carmargo, D.B. Zandonadi, V.M. Rumjanek, J.G.M. Guerra, M.G. Teixeira, and R. Braz-Filho. 2004. Organic matter quality in a soil cultivated with perennial herbaceous legumes. Sci. Agric. 61:53-61.

Chabbi, A., C. Rumpel, and I. Kogel-Knabner. 2007. Stable carbon isotope and chemical composition of organic matter in lignite-containing mine soils and sediments are closely related. Org. Geochem. 6:835-844.

Chanyasak, V., M. Hirai, and H. Kubota. 1982. Changes of chemical components and nitrogen transformation in water extracts during composting of garbage. J. Ferm. Technol. 60:439446.

Chin, Y.P., G. Alken, and E. O'Loughlln. 1994. Molecular weight, polydispersity, and spectroscopic properties of aquatic humic substances. Environ. Sci. Technol. 28:18531858.

Cilenti, A., M.R. Provenzano, and N. Sensei. 2005. Characterization of dissolved organic matter from saline soils by fluorescence spectroscopy. Environ. Chem. Lett. 3:53-56.

Collins, H. P., E.T. Elliott, K. Paustian, L.G. Bundy, W.A. Dick, D.R. Huggins, A.J.M. Smucker, and E.A. Paul. 2000. Soil carbon pools and fluxes in long-term corn belt agroecosystems. Soil Biol. Biochem. 32:157-168.

Deflandre, B., and J.P. Gagne. 2001. Estimation of dissolved organic carbon (DOC) concentrations in nanoliter samples using UV spectroscopy. Wat. Res. 35:3057-3062.

Dick, D.P., H. Knicker, L.G. Avila, A.V. Inda, E. Giasson, and C.A. Bissani. 2006. Organic matter in constructed soils from a coal mining area in southern Brazil. Org. Geochem. $37: 1537-1545$.

Ding, G., J.M. Novak, D. Amarasiriwawardena, P.G. Hunt, and B. Xing. 2002. Soil organic matter characteristics as affected by tillage management. Soil Sci. Soc. Am. J. 66:421429.

Ellerbrock, R.H. and H.H. Gerke. 2004. Characterizing organic matter of soil aggregate coatings and biopore by Fourier transform infrared spectroscopy. Eur. J. Soil Sci. 55:219228.

Ellerbrock, R.H., A. Hohn, and J. Rogasik. 1999a. Functional analysis of soil organic matter as affected by long-term manurial treatment. Eur. J. Soil Sci. 50:65-71. 
Ellerbrock, R.H.A. Hohn, and H.H. Gerke. 1999b. Characterization of soil organic matter from a sandy soil in relation to management practice using FT-IR spectroscopy. Plant Soil. 213: 55-61.

Eusterhues, K., C. Rumpel,, M. Kleber, and I. Kogel-Knabner. 2003. Stabilisation of soil organic matter by interactions with minerals as revealed by mineral dissolution and oxidative degradation. Org. Geochem. 34:1591-1600.

Eusterhues, K., C. Rumpel, and I. Kogel-Knabner. 2007. Composition and radiocarbon age of HF-resistant soil organic matter in Podzol and a Cambisol. Org. Geochem. 38:1356-1372.

Falloon, P., P. Smith, K. Coleman, and S. Marshall. 1998. Estimating the size of the inert organic matter pool from total soil organic carbon content for use in the Rothamsted carbon model. Soil Biol. Biochem. 30:1207-1211.

Gelinas, Y., K.M. Prentice, J.A. Baldock, and J.I. Hedges. 2001. An improved thermal oxidation method for quantification of soof/graphitic black carbon in sediments and soils. Environ. Soil Tech. 35:3519-3525.

Gerke, H.H., H. Hangen, W. Schaaf, and R.F. Huttl. 2001. Spatial variability of potential water repellency in a lignitic minesoil afforested with Pinus nigra. Geoderma. 102:255-274.

Gigliotti, G., A. Macchioni, C. Zuccaccia, P.L. Giusquiani, and D. Businelli. 2003. A spectroscopic study of soil fulvic acid composition after six-year applications of urban waste compost. Agronomie. 23:719-724.

Giovanni M.F. and M. Mingazzini. 1995. Synchronous fluorescence spectra of dissolved organic matter (DOM) of algal origin in marine coastal waters. Mar. Ecol. Prog. Ser. 125:305-315.

Guggenberger, G. and K. Kaiser. 2003. Dissolved organic matter in soils. Challenging the paradigm of sorptive preservation. Geoderma. 113: 293-310.

Haberhaur, G. and M.H. Garzabek. 1999. Drift and transmission FT-IR spectroscopy of forest soils: An approach to determine decomposition processes of forest litter. Vibr. Spectrosc. 19:413-417.

Haberhaur, G., B. Feigle, M.H. Garzabek, and C. Cerri, 2000. FT-IR spectroscopy of organic matter in tropical soils: Changes induced to deforestation. J. Appl. Spectrosc. 54:221-224.

Hadjia, O. and B. Spoljar. 1995. Quantitative determination of carboxylate by infrared spectroscopy: Application to humic acids. J. Anal. Chem. 351:692-693. 
Hallberg, G.R., N.C. Wollenhaupt, and G.A. Miller. 1978. A century of soil development in spoil derived from loess in Iowa. Soil Sci. Soc. Am. J. 42:339-343.

Hangen, H.H., W. Gerke, and R.F. Huttl. 2004. Flow path visualization in a lignitic mine soil using iodine-starch staining. Geoderma. 120:121-135.

Hangen, H.H., W. Gerke, and R.F. Huttl. 2005. Assessment of preferential flow processes in a forest-reclaimed lignitic mine soil by multicell sampling of drainage water and three tracers. J. Hydrol. 303:16-37

Harden, J.W. 1982. A quantitative index of soil development from field descriptions: Examples from a chronosequence in central California. Geoderma 28:1-28.

Haumaier, L. and W. Zech. 1995. Black carbon - possible source of highly aromatic components in soil humic acids. Org. Geochem. 23:191-196.

Hautala, K., J. Peuravouri, and K. Pihlaja. 2000. Measurement of aquatic humus content by spectroscopic analysis. Wat. Res. 34:246-258.

Helfrich, M., H. Flessa, R. Mikutta, A. Dreves, and B. Ludwig, B. 2007. Comparison of chemical fractionation methods for isolating stable soil organic carbon pools. Eur. J. Sol Sci. 58:1316-1329.

Houghton, R.A. 1995. Changes in the storage of terrestrial carbon since 1850, In: Soils and Global Change. (eds). Lal, R., Kimble, J., Levine, E., Stewart, B.A. CRC \& Lewis Publishers, Boca Raton, FL. p. 45-65.

Hugget, R.J. 1998. Soil chronosequences, soil development, and soil evolution: A critical review. Catena 32:155-172.

Hunt, J.F. and T. Ohno. 2007. Characterization of fresh and decomposed dissolved organic matter using excitation-emission matrix fluorescence spectroscopy with multiway analysis. J. Agr. Food Chem. 55:2121-2128.

Inbar, Y., Y. Chen, Y. Hadar. 1989. Solid state carbon-13 nuclear magnetic resonance and infrared spectroscopy of composted organic matter. Soil Sci Soc. Am. J. 53:1695-1701.

IPCC. 2000. Land Use, Land Use Change, and Forestry. Cambridge University Press, Cambridge, UK.

Jacinthe, P.A. and R. Lal. 2007. Carbon storage and minesoil properties in relation to topsoil application techniques. Soil Sci. Soc. Am. J. 71:1788-1791. 
Jastrow, J.D., T.W. Boutton, and R.M. Miller. 1996. Carbon dynamics of aggregate-associated organic matter estimated by carbon-13 natural abundance. Soil Sci. Soc. Am. J. 60:801807.

Johnson, C.D., and J.G. Skousen. 1995. Minesoil properties of abandoned mine land sites in West Virginia. J. Environ. Qual. 24:635-643.

Kaiser, K., K. Eusterhues, C. Rumpel, G. Guggenberger, and I. Kogel-Knabner. 2002. Stabilization of organic matter by soil minerals - investigations of density and particlesize fractions from two acid forest soils. J. Plant Nutr. Soil Sci. 165: 451-459.

Kasper, T.C.,T.B. Parkin, D.B. Jaynes, C.A. Camberdella, D.W. Meek, and Y.S. Jung. 2006. Examining changes in soil organic carbon with oat and rye cover crops using terrain covariates. Soil Sci. Soc. Am. J. 70:1168-1177.

Kalbitz, K., W. Geyer, and S. Geyer. 1999. Spectroscopic properties of dissolved humic substance - a reflection of the landuse history in the fen area. Biogeochem. 47:219-238.

Kalbitz, K., S. Geyer, and W. Geyer. 2000. A comparative characterization of dissolved organic mattter by means of original aqueous samples and isolated humic substances. Chemosphere. 40:1305-1312.

Kalbitz, K. and W. Geyer. 2001a. Humification indices of water-soluble fulvic acids derived from synchronous fluorescence spectra - effect of spectrometer type and concentration. J. Plant Nutr. Soil Sci. 164:259-265.

Kalbitz, K. 2001b. Properties of organic matter in soil solution in a German fen area as dependent of landuse and depth. Geoderma. 104:203-214.

Kalbitz, K.; Schwesig, D.; Rethemeyer, J. and Matzner, E. 2005. Stabilization of dissolved organic matter by sorption to the mineral soil. Soil Biol. Biochem. 37:1319-1331.

Karltun, E. 1998. Modelling $\mathrm{SO}_{4}^{-2}$ surface complexation on variable charge minerals: II. Competition between $\mathrm{SO}_{4}{ }^{-2}$, oxalate and fulvate. Eur. J. Soil Sci. 49:113-120.

Khorsin, G.Y., C.W. Li, and M.M. Benjamin, M. M. 1997. Monitoring the properties of natural organic matter through UV spectroscopy: A consistent theory. Wat. Res. 31: 1787-1795.

Kim, H.C. and M.J. Yu. 2005. Characterization of natural organic matter in conventional water treatment processes for selection of treatment focused on DBPs control. Wat. Res. 39: 4779-4789.

Kononova, M. 1966. Soil Organic Matter. $2^{\text {nd }}$ edition. Permagon. Oxford. p. 404. 
Kukkonen, J. 1992. Effects of lignin and chlorolignin in pulp mill effluents in the binding and bioavailability of hydrophobic organic pollutants. Wat. Res. 26:1523-1532.

Lal, R., J. Kimble, R. Follett, and C. V. Cole. 1998. The Potential of US Cropland to Sequester Carbon and Mitigate the Greenhouse Effect. Sleeping Bear Press Inc. Ann Arbor. MI.

Lal, R. and J.P. Bruce. 1999. The potential of world cropland soils to sequester C and mitigate the greenhouse effect. Environ. Sci. Policy. 2: 77-185.

Lal, R. and D. Ussiri. 2005. Carbon sequestration in reclaimed minesoils. Plant Sciences Critical Reviews. http://www.highbeam.com/doc/1P3-890304481.html

Zvomuya, F., F.J. Larney, P.R. Demaere, and A.F. Olsen. 2007. Reclamation of abandoned natural gas wellsites with organic amendment: Effects on soil carbon, nitrogen, and phosphorous. Soil Sci. Soc. Am. J. 71:1186-1193.

Leavitt, S.W.; R.F. Follett, and E.A. Paul. 1996. Estimation of slow- and fast-cycling soil organic carbon pools from 6N HCl hydrolysis. Radiocarbon 38:231-239.

Maharaj, S., C.D. Barton, T.A. Karathanasis, H.D. Rowe, and S.M Rimmer. 2007a. Distinguishing "New" from "Old" organic carbon in reclaimed coal mine sites using thermogravimetry: I. Methods development. Soil Sci. 172:292-302.

Maharaj, S., C.D. Barton, T.A. Karathanasis, H.D. Rowe, and S.M Rimmer. 2007b. Distinguishing "New" from "Old" organic carbon in reclaimed coal mine sites using thermogravimetry: II. Field validation. Soil Sci. 172:302-312.

Miano, T. M. and N. Senesi. 1992. Synchronous excitation fluorescence spectroscopy applied to soil humic substances chemistry. Sci. Total Environ. 117:41-51.

Mummey, D.L., P.D. Stahl, and J.S. Buyer. 2002. Soil microbiological properties 20 years after surface mine reclamation: Spatial Analysis of reclaimed and undisturbed sites. Soil Biol Biochem. 34:1717-1725.

Mikutta, R., M. Kleber, M.S.Torn, and R. Jahn. 2006. Stabilization of soil organic matter: association with mineral or chemical recalcitrance? Biogeochemistry. 77:25-56.

Mikutta, R., M. Kleber, K. Kaiser, and R. Jahn. 2005. Review: organic matter removal from soils using hydrogen peroxide, sodium hypochlorite and disodium peroxodisulfate. Soil Sci. Soc. Am. J. 69:120-136. 
Nyamadzawo, G., M.K. Shukla, and R. Lal. 2007. Spatial variability of total soil organic carbon and nitrogen stocks for some reclaimed minesoils of southeastern Ohio. Land. Degrad. Develop. 19:275-288.

Oliviera, J.L., M. Boroski, J.C.R. Azevedo, and J. Nozaki. 2006. Spectroscopic investigation of humic substances in a tropical lake during a complete hydrological cycle. Acta. Hydrochim. Hydrobiol. 34:608-617.

Ostle, N.J., R. Bol, K.J. Petzke, and S.C. Jarvis. 1999. Compound specific 15N\%o values: Amino acids in grassland and arable soils. Soil Biol. Biochem.. 31:1751-1755.

Paul, E.A., K. Paustian, E.T. Eliott, and C.V. Cole (eds.). 1997. Soil Organic Matter in Temperate Agroecosystems: Long Term Experiments in North America. CRC Press. Boca Raton, FL. pp. 430.

Paul, E.A., S.J. Morris, and S. Bohm, 2000. The determination of soil C pool sizes and turnover rates: biophysical fractionation and tracers. In: Assessment Methods for Soil Carbon. (eds) R. Lal, J.M. Kimble, R.F. Follett \& B.A. Stewart), pp. 193-206. CRC Press, Boca Raton, FL.

Paul, E.A., S.J. Morris, R.T. Conant, and A.F. Plante. 2006. Does the acid hydrolysisincubation method measure meaningful soil organic carbon pools? Soil Sci. Soc. Am. J. 70:1023-1035.

Peuravuori, J., R. Koivikko, and K. Pihlaja. 2002. Characterization, differentiation and classification of aquatic humic matter separated with different sorbents: Synchronous scanning fluorescence spectroscopy. Wat. Res. 36:4552-4562

Peuravuori, J. and K. Phihlaja. 1997. Molecular size distribution and spectroscopic properties of aquatic humic substances. Anal. Chim. Acta. 337:133-149.

Pillans, B. 1997. Soil development at snail's pace: Evidence from 6 Ma soil chronosequences on basalt in north Queensland, Australia. Geoderma 80:117-128.

Poirier, N., S. Derenne, J. Balesdent, A. Mariotti, D. Massiot, and C. Largeau. 2003. Isolation and analysis of the non-hydrolysable fraction of a forest soil and an arable soil (Lacade' e, southwest France). Eur. J. Soil Sci. 54:243-255.

Puget, P. and R. Lal. 2005. Soil organic carbon and nitrogen in a Mollisol in central Ohio as affected by tillage and land use. Soil Till. Res. 80:201-213. 
Quenea, K., S. Derenne, C. Largeau, C. Rumpel, and A. Mariotti, 2005. Spectroscopic and pyrolytic features and abundance of the macromolecular refractory fraction in a sandy forest soil (Landes De Gascogne, France). Org. Geochem. 36:349-362.

Rivero, C., T. Chirenje, L.Q. Ma, and G. Martinez. 2004. Influence of compost on soil organic matter quality under tropical conditions. Geoderma. 123:355-361.

Rodrigue, J.A. and J.A. Burger. 2004. Forest soil productivity of mined land in the midwestern and eastern coalfield regions. Soil Sci. Soc. Am. J. 68:833-844.

Rosenzweig, C. and D. Hillel. 2000. Soils and global climate change: Challenges and opportunities. Soil Sci. 165:47-56

Rumpel, C., H. Knicker, I. Kogel-Knabner, R.F. Hutl. 1998. Airborne contamination of immature soil (Lusatian mining district) by lignite-derived materials: Its detection and contribution to soil organic matter budgets. In Dick, D. P.; Knicker, H.; Avila, L. G.; Inda, A. V. Jr.; Giasson, E. and Bissani, C. A. 2006. Organic matter in constructed soils from a coal mining area in southern Brazil. Org. Geochem. 37:1537-1545.

Rumpel C., A. Seraphin, M. Dignac, W. Michaelis, K. Eusterhues, I. Kogel-Knabner. 2005. Effect of base hydrolysis on the chemical composition of organic matter of an acid forest soil. Org. Geochem. 36:239-249.

Schafer, W.M., G.A. Nielson, and W.D. Nettleton. 1980. Minesoil genesis and morphology in a spoil chronosequence in Montana. Soil Sci. Soc. Am. J. 144:802-807.

Schlamadinger, B. and G. Marland. 2000. Land use and global climate change: Forest, Land management, and the Kyoto Protocol. Pew Center of Global Climate Change, Arlington, VA. p. 54.

Schlesinger, W.H. 1991. Biogeochemistry: An Analysis of Global Change. Academic Press, Inc, San Diego. p. 588.

Senesi, N., T. Miano, M.R. Provenzano, and G. Brunetti. 1989. Spectroscopic and compositional comparative characterization of I.H.S.S. reference and standard fulvic and humic acids of various origin. Sci. Total Environ. 81:143-156.

Senesi, N., T. Miano, M.R. Provenzano, and G. Brunetti. 1991. Characterization, differentiation, and classification of humic substances by fluorescence spectroscopy. Soil Sci. 152:259271. 
Shrestha, R.K. and R. Lal. 2006. Ecosystem carbon budgeting and soil carbon sequestration in reclaimed minesoils. Environ. Int. 32:781-796.

Shrestha, R.K. and R. Lal. 2008. Land use impacts on physical properties of 28 years old reclaimed mine soils in Ohio. Plant Soil. 306:249-260.

Shukla, M.K,, R.Lal, and D. VanLeeuwen. 2007. Spatial variability of carbon and nitrogen contents in the reclaimed minesoils of eastern Ohio. Soil Sci. Soc. Am. J. 71:1748-1757.

Shukla, M.K., R. Lal, and M.H. Ebinger. 2005. Physical and chemical properties of a minespoil eight years after reclamation in northeastern Ohio. Soil Sci. Soc. Am. J. 69:1288-1297.

Shukla, M.K., R. Lal, J. Underwood, and M. Ebinger. 2004a. Physical and hydrological characteristics of reclaimed minesoils in southeastern Ohio. Soil Sci. Soc. Am. J.68:1352-1359.

Shukla, M.K., R. Lal, and M. Ebinger. 2004b. Soil quality indicators for reclaimed minesoils in southeastern Ohio. Soil Sci. 169:133-142.

Siewert, C. 2004. Rapid screening of soil properties using thermogravimetry. Soil Sci. Soc. Am. J. 68:1656-1661.

Simpson, M.J. and P.G. Hatcher. 2004. Determination of black carbon in natural organic matter and solid-state ${ }^{13} \mathrm{C}$ nuclear magnetic resonance spectroscopy. Org. Geochem. 35:923-935.

Six, J., H. Bossuyt, S. Degryze, and K. Denef, 2004. A history of research on the link between (micro)aggregates, soil biota, and soil organic matter dynamics. Soil Till. Res. 79:7-31.

SMCRA, 1977. Surface Mining Control and Reclamation Act. Public Law 95-87. US. Code Vol. 30, Sec 1265.

Smidt, E., P. Lechner, M. Schwanninger, G. Haberhaur, and M.H. Gerzabek. 2002.

Characterization of waste organic matter by FT-IR spectroscopy: Application in waste science. J. Appl. Spectrosc. 56:1170-1175.

Solomon, D., J. lehmann, J. Kinyangi, B. Liang, and T. Schafer. 2005. Carbon K-Edge NEXAFS and FTIR-ATR spectroscopic investigation of organic carbon speciation in soils. Soil Sci. Soc. Am. J. 69:107-119.

Spaccini, R., A. Piccolo, G. Haberhaur, M. Stemmer, and M.H. Gerzabek. 2001. Decomposition of maize straw in three European soils as revealed by DRIFT spectra of soil particle fractions. Geoderma. 99:245-260. 
Tan, Z. X., R. Lal, R.C. Izaurralde, and W.M. Post. 2004. Biochemically protected soil organic carbon at the North Appalachian experimental watershed. Soil Sci. 196:423-433.

Thomas, D., and I. Jansen. 1985. Soil development in coal mine spoils. J. Soil Water Conserv. 40:439-442.

Thomas, K.A., J.C. Sencindiver, J.G. Skousen, and J.M. Gorman. 2000. Chemical properties of minesoils on a mountaintop removal mine in southern West Virginia. Proc. Natl. Meeting ASSMR. 2:448-455.

Ussiri, D.A.N., R. Lal, and P.A. Jacinthe. 2006. Soil properties and carbon sequestration of afforested pastures in reclaimed minesoils in Ohio. Soil Sci. Soc. Am. J. 71:1797-1806.

Ussiri, D.A.N. and R. Lal. 2008. Method for determining coal carbon in reclaimed minesoils contaminated with coal. Soil Sci. Soc. Am. J. 72:231-237.

Valesco, M.I., P.A. Campitelli, S.B. Ceppi, and J. Havel. 2004. Analysis of humic acid from compost or urban wastes and soil by fluorescence spectroscopy. Agriscientia. 21:31-38.

Volk, C.L., B. Wood, J. Johnson, H.W. Robinson, H.W. Zhu, and L. Kaplan. 2004. Monitoring dissolved organic carbon in surface and drinking waters. J. Environ. Monit. 4:43-47.

Weishaar, J.L, G.R. Aiken, B.A. Bergamaschi, M.S. Fram, R. Fuji, and R.K. Mopper. 2003. Evaluation of specific ultraviolet absorbance as an indicator of the chemical composition and reactivity of dissolved organic carbon. Environ. Sci. Technol. 37:4702-4708.

Westerhoff, P., and D. Anning. 2001. Concentration and characteristics of organic carbon in surface water in Arizona: Influence of urbanization. J. Hydrol. 236:202-222.

Woodbury, P.B., P.S. Heath, and J.E. Smith. 2006. Land use change effects on forest carbon cycling throughout the southern United States. J. Environ. Qual. 35:1348-63.

Zimmerman, M.; Leifield, J.; Abiven, A.; Schimdt, M. W. I. and Fuhrer, J. 2007. Sodium hypochlorite separates an older soil organic matter fraction than acid hydrolysis. Geoderma. 139: 171-179.

Zvomuya, F., F.J. Larney, P.R. Demaere, and A.F. Olsen. 2007. Reclamation of abandoned natural gas wellsites with organic amendment: Effects on soil carbon, nitrogen, and phosphorous. Soil Sci. Soc. Am. J. 71:1186-1193. 


\title{
CHAPTER 3:
}

Land Use Effects on Sample Size Requirements for Soil Organic Carbon Stock Estimations

\begin{abstract}
Soil organic carbon stock (SOC stock, $\mathrm{Mg} \mathrm{C} \mathrm{ha}^{-1}$ ) is calculated from SOC concentration (SOC, $\mathrm{g} / \mathrm{kg}$ ) and soil bulk density $\left(\rho_{\mathrm{b}}, \mathrm{g} \mathrm{cm}^{-3}\right)$. Temporal changes in SOC stock are used to calculate terrestrial carbon sequestration rates used in global climate change models. The inherent variability in soil properties like SOC and $\rho_{\mathrm{b}}$ means that larger sample sizes may be needed to accurately determine SOC stocks. Our objective was to calculate the minimum sample size required to detect changes in $\rho_{\mathrm{b}}$, SOC and SOC stock for two land uses. Surface soils $(0-5 \mathrm{~cm})$ from two reclaimed minesoils and two managed hay fields in northern West Virginia were intensively sampled (60 to 74 samples each). Mean SOC and SOC stock values were larger in the hay fields $\left(40 \mathrm{~g} / \mathrm{kg}, 29 \mathrm{Mg} \mathrm{ha}^{-1}\right)$ than in the minesoils $\left(20 \mathrm{~g} / \mathrm{kg}, 20 \mathrm{Mg} \mathrm{ha}^{-1}\right)$, but $\rho_{\mathrm{b}}$ was larger in reclaimed minesoils $\left(1.4 \mathrm{~g} \mathrm{~cm}^{-3}\right)$ than in hay field soils $\left(1.2 \mathrm{~g} \mathrm{~cm}^{-3}\right)$. The $\rho_{\mathrm{b}}$ variance was larger in minesoils than hay field soils, but field variances for a given land use were similar $(0.09$ and $0.11\left(\mathrm{~g} \mathrm{~cm}^{-3}\right)^{2}$ in minesoils; 0.02 and $0.03\left(\mathrm{~g} \mathrm{~cm}^{-3}\right)^{2}$ in hay field soils). The variance in SOC concentration and SOC stock were not related to land use and were not similar within a land use. As a result, the minimum number of samples required to detect a change in $\rho_{\mathrm{b}}$, SOC and SOC stock was a site-specific property and cannot be assumed $a$ priori.
\end{abstract}

Keywords: Soil organic carbon stock, sample size, minesoils, bulk density 


\subsection{Introduction}

In the Appalachian region, surface mining is a prominent land use (Townsend et al., 2009) that alters soil physical, chemical, and biological characteristics (Indorante et al., 1981; Shukla et al., 2004; Lal and Ussiri, 2005). After the reclamation of these mined areas, a new soil begins to form. Minesoils are newly formed man-sculpted soils which are developed after a mining operation has finished production. Minesoils consist of a collection of blasted material which was removed during the mining process. With appropriate reclamation methods and sufficient time, reclaimed minesoils can sequester significant amounts of carbon (Akala and Lal, 2000, 2001; Shukla et al. 2005a, 2005b; Shrestha and Lal, 2006a, 2006b). After 100 years of soil formation on loess-derived spoils in Iowa, the soil organic carbon stock (SOC stock) in the upper 10 to $50 \mathrm{~cm}$ was 26 and $82 \mathrm{Mg} \mathrm{C} \mathrm{ha}^{-1}$, respectively (Hallberg et al., 1978). In a chronosequence of six coal mine spoils in Illinois, SOC stocks increased by 0.1 and $0.3 \mathrm{Mg} \mathrm{C} \mathrm{ha}^{-1} \mathrm{yr}^{-1}$ in the upper $10 \mathrm{~cm}$ and $50 \mathrm{~cm}$, respectively (Thomas and Jansen, 1985). The net rate of positive change following conversion of severely degraded land to agricultural or forest land could be as high as $0.25 \mathrm{Mg} \mathrm{C} \mathrm{ha}^{-1} \mathrm{yr}^{-1}$ (Lal and Bruce, 1999). Carbon sequestration in degraded lands has the potential to offset some of the increased atmospheric $\mathrm{CO}_{2}$ concentrations implicated in global climate change (Lal, 2004). Sequestered carbon levels are typically expressed as SOC stock (Mg $\mathrm{C} \mathrm{ha}{ }^{-1}$ ) and calculated as the product of SOC concentration, soil bulk density $\left(\rho_{\mathrm{b}}\right)$, and soil sampling depth (Akala and Lal, 2001; Sperow, 2006, Jacinthe and Lal, 2007).

Reclamation activities, including backfilling with overburden materials, topsoiling, and regrading to original contours (Jacinthe and Lal, 2007; Townsend et al., 2009) can produce significant variation in minesoil properties. The use of heavy machinery, topsoil replacement, and the random mixing of dissimilar materials, combined with a lack of biological activity and root networks, poorly developed soil structure and certain post-reclamation management practices, result in high, and highly variable, minesoil bulk density (Ashby et al., 1984; Skousen et al., 1998; Guebert and Gardner, 2001; Shukla et al., 2005a, 2007; Nyamadzawo et al., 2007). This greater variability increases the sample size requirements needed to accurately determine values for the soil properties used to estimate SOC stock.

Estimates of SOC stock have been made using a single mean $\rho_{\mathrm{b}}$ value and a single SOC determination on a composite sample (Akala and Lal, 2000, 2001; Jacinthe and Lal, 2007). This leads immediately to questions of accuracy and statistical power. Our objective was to determine 
the minimum sample size required to estimate SOC, $\rho_{\mathrm{b}}$, and SOC stock values for two land uses that reflect disturbance extremes; reclaimed surface minesoils and managed hay field soils.

\subsection{Materials and Methods}

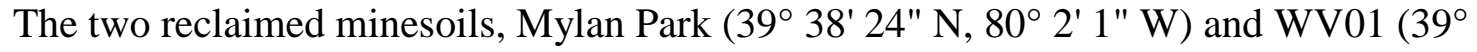
40' 23" N, 80 3' 16" W), were located near Morgantown, West Virginia. The topography in this region is characterized by mountain ranges with rounded ridge tops, steep hill slopes and narrow valleys. The exposed rocks in this area include interbedded limy and acidic gray shale, siltstone, sandstone, coal, limestone, and a few thin beds of calcareous red shale of the Dunkard, Monongahela and Conemaugh Groups.

Both WV01 and Mylan Park (MP) were owned, mined, and reclaimed by the same company. The sites were mined using contour mining methods with front-end loaders and trucks. After coal removal, overburden was replaced and regraded to the approximate original contour. Topsoil to depths of 10 to $20 \mathrm{~cm}$ was placed and compacted with bulldozers. Seeded plant species were tall fescue (Festuca arundinacea), bird's foot trefoil (Lotus corniculatus), and rye grass (Lolium perenne). Mylan Park was reclaimed 21 years ago and WV01 was reclaimed less than 2 years ago. Predominant species found at MP were orchardgrass (Dactylis glomerata), alfalfa (Medicago sativa), red clover (Trifolium pratense), white clover (Trifolium repens), timothy (Phelum pratense L.), tall fescue (Festuca arundinacea), and bird's foot trefoil (Lotus corniculatus).

The managed hay field sites (HF1 and HF2) were located at the West Virginia University Reedsville Experimental Farm $\left(79^{\circ} 47 \mathrm{~W}, 39^{\circ} 30 \mathrm{~N}\right)$ in Preston County, West Virginia. Average winter and summer temperatures at the site are $-2^{\circ} \mathrm{C}$ and $20^{\circ} \mathrm{C}$, respectively, with average annual rainfall and snowfall of $125 \mathrm{~cm}$ and $147 \mathrm{~cm}$, respectively. The hay fields consisted mainly of orchardgrass (Dactilis glomerata L.), timothy (Phleum pretense L.), alfalfa (Medicago sativa L.) and smaller proportions of white clover (Trifolium repens L.) and red clover (T. pratense L.). Hay was cut twice per year (May and June). Nitrogen fertilizer was applied before and after each cutting at a rate of $84 \mathrm{~kg} \mathrm{~N} / \mathrm{ha}$, to give a total of $252 \mathrm{~kg} \mathrm{~N} / \mathrm{ha} / \mathrm{yr}$. The topography of the study area is uniform with broad level ridges and side-slopes ranging from 3 to $25 \%$. 


\subsubsection{Sample Collection and Preparation}

At each mine site 0 to $5 \mathrm{~cm}$ depth soil samples were collected for SOC and $\rho_{\mathrm{b}}$ in late summer (August-September 2008), in a nonaligned $7 \mathrm{~m}$ by $5 \mathrm{~m}$ grid, over an area of approximately 0.5 ha. Soil bulk density was determined using a modified excavation method (Blake and Hartge, 1986) with a $12.5 \mathrm{~cm}$ diameter auger. A fine sheet of plastic was placed inside the excavated hole and fine sand was then poured and gently compacted to match site topography. A graduated cylinder was used to measure the initial and final volumes of sand; the difference representing the volume of excavated soil. Gravel-corrected soil bulk density (Ussiri et al., 2006) was also calculated. For the managed hay field sites, 0 to $5 \mathrm{~cm}$ depth soil samples were collected in a $7 \mathrm{~m}$ by $7 \mathrm{~m}$ nonaligned grid earlier, in the summer (July 2008), over an area of approximately 0.5 ha. Soil bulk density samples were taken with a Uhland sampler (Uhland, 1949).

Soil organic carbon concentrations were determined by automated complete combustion (LECO Tru Spec CHN, Cary, MI). The SOC stock calculations were both (1) point-based, using the SOC and $\rho_{b}$ determined at each sampling point,

$$
M g \quad C_{p b}\left(h a^{-1}\right)=\frac{\operatorname{SOC}^{j} \times \rho_{b}^{j} \times d \times 10^{4} m^{2} h a^{-1}-}{100}
$$

and (2) mean-based, using the average $\rho_{\mathrm{b}}$ for each site and the SOC determined at each sampling point,

$$
M g \quad C_{m b}\left(h a^{-1}\right)=\frac{\operatorname{S} O C^{j} \times \overline{\rho_{b}} \times d \times 10^{4} m^{2} h a^{-1}-}{100}
$$

where $\mathrm{j}$ represents a sampling location within site $\mathrm{i}$ (WV01, MP, HF1, or HF2), SOC is the SOC

concentration in $\mathrm{g} \mathrm{kg}^{-1}, \rho_{\mathrm{b}}^{\mathrm{j}}$ is soil bulk density at sampling location $\mathrm{j}$, and $\overline{\rho_{\mathrm{b}}}$ is the site-average bulk density $\left(\mathrm{g} \mathrm{cm}^{-3}\right), \mathrm{d}$ is sampling depth (m) and $\mathrm{Mg} \mathrm{C} \mathrm{ha}^{-1}$ is SOC stock.

\subsubsection{Statistical Analysis}

A sensitivity analysis was performed to determine the minimum number of samples necessary to characterize SOC, $\rho_{\mathrm{b}}$, and SOC stock as a function of a user-defined absolute difference (Snedecor and Cochran, 1989) using:

$$
\hat{\mathrm{n}}=\frac{\mathrm{s}^{2} \times 1.96^{2}}{\mathrm{~L}^{2}}
$$


where $\hat{n}$ is the minimum number of samples needed to detect the difference $L, s^{2}$ is the sample variance at each site, and 1.96 is a constant representing $t_{\alpha}$ for infinite degrees of freedom at the $95 \%$ level of confidence $(\alpha=0.05)$. Sites were compared as regards SOC concentration, $\rho_{\mathrm{b}}$, and SOC stock by analysis of variance using the PROC GLM procedure in SAS 9.1.3 for Windows (SAS Institute, 2003, Cary, NC). Treatment means were compared using Fisher's Least Significant Difference (LSD) at the $95 \%$ level of confidence (probability of a greater $F \leq 0.05$ ). Correlation analyses were performed between point-based (Eq. 1) and mean-based (Eq. 2) SOC stocks at each site. Regression analyses were performed between mean-based and point-based SOC stocks. Residuals were calculated by subtracting mean-based SOC stock values predicted by the regression model from point-based (observed) values. To study residual trends, residuals were plotted against the point-based SOC stock values.

\subsection{Results and Discussion}

\subsubsection{Soil bulk density and soil organic carbon characterization}

Soils in both hay fields exhibited larger SOC values than those for either of the minesoils, and the older minesoil (MP) exhibited larger SOC values than did the younger WV01 site (Table 1). Similar results were observed in reclaimed minesoils and undisturbed grasslands in Wyoming, USA (Mummey at al., 2002). Soil bulk density was greater in minesoils than in hay field soils, with WV01 exhibiting a greater density than MP (Table 3-1). These observations are consistent with previously observed impacts due to the disturbance that occurs before mining when topsoil is removed and stockpiled, the compaction that results from the reclamation process, and the subsequent recovery of soil physical quality with time subsequent to reclamation (Guebert and Gardner, 2001; Shukla et al., 2005a, b; Ussiri et al., 2006). The SOC stocks were significantly larger in the hay field soils than in the minesoils, more than twice that at WV01 and about 1.5 times that at MP (Table 3-1). The SOC and $\rho_{b}$ values have the same weight in the equation used to calculate SOC stock (Eq. 1 and 2), and a unit change in SOC has the same effect on SOC stock as a unit change in $\rho_{\mathrm{b}}$. Therefore, the larger SOC at MP had a larger effect on SOC stock than did the smaller $\rho_{\mathrm{b}}$. Coefficient of variation $(\mathrm{CV})$ values for SOC did not show a pattern that could be attributed to land use. For $\rho_{b}$ and SOC stock, CV values for minesoils were larger than those for hay field soils, except that the SOC stock CV for WV01 was similar to that for HF1 (Table 3-1). Significantly lower SOC and higher $\rho_{\mathrm{b}}$ values in the minesoils are 
probably the consequence of reduced biological activity, mechanical compaction, and a lack of root networks in these intensely disturbed soils.

\subsubsection{Sample number requirement}

The greater variance in minesoil $\rho_{\mathrm{b}}$ resulted in a larger minimum number of samples required to detect a given change in $\rho_{\mathrm{b}}$, as compared that for the hay field soils (Figure 3-1a). For example, to detect a difference in $\rho_{\mathrm{b}}$ of $0.1 \mathrm{~g} \mathrm{~cm}^{-3}$ at the $95 \%$ level of confidence would require more than 190 samples in the minesoils, but only between 16 and 64 samples in the managed hay field soils. For SOC values, the minimum required sample size increased as the variance increased, as expected, but there was no clear pattern attributable to land use (Figure 3-1b). The older minesoil, Mylan Park, required more samples than its younger counterpart, WV01. This result could be the consequence of the lower absolute SOC at WV01, due in part to lower plant species diversity (data not shown). The disturbance of the managed hay field soils, as compared with the reclaimed minesoils, was insignificant. High CV values for SOC have been reported for relatively undisturbed soils (Conant and Paustian, 2002; Conant et al., 2003; Kravchenko et al., 2006; Yanai et al., 2005; Palmer et al., 2002; Takata et al., 2007), observations in accord with what we observed for these hay field soils. The greater variability in SOC found in the hay field sites was also found by Hay (2006). Hay (2006) explained the high variability in SOC concentrations in managed hay field soils as a result of grazing behavior and the development of microclimates in an otherwise relatively stable ecosystem.

In determining the number of samples needed to determine SOC stock values, the four sites were divided into two groups, but these groups were not related to land use (Figure 3-1c). Regardless of the significance level tested $(\alpha=0.10,0.05$ or 0.01$)$ a similar number of samples was required at MP and HF1, and also at WV01 and HF2, to statistically define a $10 \%$ change in SOC (Table 3-2). For $\rho_{\mathrm{b}}$, less than 29 samples were required at all sites. For SOC stock, the largest sample size was required at MP, followed by WV01, and then the hay field soils. Time since reclamation, minesoil age, and degree of disturbance may explain this observation.

\subsubsection{Point-based versus mean-based SOC stock estimates}

Field $\rho_{\mathrm{b}}$ measurements are time consuming. The following analysis was performed to evaluate the effect of using a single site-average bulk density value to calculate a mean-based 
SOC stock as compared to a point-based estimate of SOC stock. Regression analysis revealed a weak positive relationship ( $\mathrm{R}^{2}$ of 0.56 and 0.49 for MP and WV01, respectively) between the point-based, and mean-based SOC stock values for the reclaimed minesoils while a stronger positive relationship ( $\mathrm{R}^{2}$ of 0.85 and 0.54 for HF1 and HF2, respectively) was observed for the hay field soils (Table 3-3). To test the deviation of the observed linear regression relationship between the observed, point-based SOC stock values and the predicted, mean-based SOC stock values from a perfect 1:1 linear relationship between these two variates, a "coincidence" test (Pothoff analysis; Potthoff, 1966) was performed. For two regression line to be coincident the slope and intercept should not be significantly different, and in case of a 1:1 linear relationship, the slope should not be statistically different from 1 , and the intercept should not be significantly different from 0 . The results of the analysis revealed that for all sites, the relationship between predicted (mean-based) SOC stocks and observed (point-based) SOC stocks deviated significantly $(\alpha=0.05)$, in both slope and intercept from those for the 1:1 linear relationship (Table 3-3).

The significant deviation of the regression relationships from the 1:1 relationship at all sites indicated that the use of a site-average $\rho_{b}$ value can introduce significant error into SOC stock estimates. Therefore, the substitution of a site-average $\rho_{b}$ for point-to-point $\rho_{b}$ measurements is not recommended. This conclusion applies regardless of the lower minimum sample size and $\rho_{\mathrm{b}}$ variation exhibited by the hay fields.

The regression residuals analysis indicated that there was no trend or pattern in the residuals (no over or underestimation of mean-based values at higher or lower point-based values) for minesoil SOC stock values (Figure 3-2). However, unlike the minesoils, there was a pattern when the residuals were plotted against the point-based SOC stock values for the hay field soils (Figure 3-3). This indicates that not all of the mean-based SOC stock variation was explained by the regression functions.

The analysis indicates that if estimates of minesoil SOC stocks had been made using a single site-average $\rho_{b}$ value and a single SOC value obtained from a composite sample (Akala and Lal, 2000; 2001; Jacinthe and Lal, 2007), overestimations as high as $1 \mathrm{Mg} \mathrm{C}\left(\mathrm{ha}^{-1}\right)$, and underestimations as high as $4 \mathrm{MgC}\left(\mathrm{ha}^{-1}\right)$ could have been made (Figure 2). The over- or underprediction of SOC stocks at points in space, using the mean-based approach, was more problematic for the hay field soils. The difference in variation due to SOC (high) and $\rho_{\mathrm{b}}$ (low) for 
the hay field soils led to a pattern in the residuals that would affect the accuracy and precision of mean-based SOC stock values (Figure 3-3).

In summary, proper characterization of a soil property at a given site requires some effort be devoted to determining the variance and minimum sample size requirement. In this study, the variability in the properties measured in disturbed minesoils was sometimes comparable to that found in relatively undisturbed hay field soils, indicating that variance cannot be presumed from land use. The appropriate sample size should be determined for each site and soil property. The resources available for sampling, sampling objectives, and the accuracy and precision required by the end user will define the sampling strategy used by the investigator. Knowledge of the variability in the parameters used to calculate SOC stock values is needed to better estimate this important soil storage parameter.

Calculating SOC stock using average bulk density values may result in under- or overestimation of the SOC stock at any given point in the landscape regardless of land use and any spatial or temporal variability in soil properties. The error in the estimate of SOC stock will affect carbon sequestration study conclusions, and may result in inaccurate economic and environmental modeling. 


\section{References}

Akala, V.A., and R. Lal. 2000. Potential for mine land reclamation for soil organic carbon sequestration in Ohio. Land Degrad. Develop. 11:289-297.

Akala, V.A., and R. Lal. 2001. Soil organic pools and sequestration rates in reclaimed minesoils in Ohio. J. Environ. Qual. 30:2090-2104.

Ashby, W.C., W.G. Vogel, C.A. Kolar, and G.R. Philo. 1984. Productivity of Stony Soils on Strip mines. p 31-44. Erosion and Productivity of Soils Containing Rock Fragments. Soil Sci. Soc. Am. Madison, WI.

Blake, G.R., and K. H. Hartage. 1986. Bulk density. p.363-382. In: A. Klute (ed.). Methods of soil analysis, Part 1, Physical and mineralogical methods. ASA-SSSA, Madison, WI.

Conant, R.T. and K. Paustian. 2002. Spatial variability of soil organic carbon in grasslands: implications for detecting change at different scales. Environ. Pollut. 116:127-135.

Conant, R.T., G.R. Smith, and K. Paustian. 2003. Spatial variability of soil carbon in forested and cultivated sites: Implications for change detection. J. Environ. Qual. 32:278-286.

Guebert, M.D., and T.W. Gardner. 2001. Macropore flow on a reclaimed surface mine: Infiltration and hillslope hydrology. Geomorphology. 39:151-169.

Hallberg, G. R., N. C. Wollenhaupt, and G. A. Miller. 1978. A century of soil development in spoil derived from loess in Iowa. Soil Sci. Soc. Am. J. 42: 339-343.

Hay, R.K.M. 2006. The microclimate of an upland grass. Grass Forage Sci. 40:201-212.

Indorante, S.J., I.J. Jansen, and C.W. Boast. 1981. Surface mining and reclamation: Initial changes in soil character. J. Soil Water Conserv. 36: 47-351.

Jacinthe, P.A. and R. Lal. 2007. Carbon storage and minesoil properties in relation to topsoil application techniques. Soil Sci. Soc. Am. J. 71:1788-1791.

Kravchenko, A.N., G.P. Robertson, S.S. Snap, and A.J.M. Smucker. 2006. Using information about spatial variability to improve estimates of total soil organic carbon. Soil Sci. Soc. Am. J. 98:823-829.

Lal, R. 2004. Agricultural activities and the global carbon cycle. Nutr. Cycl. Agroecosyst. 70:103-116.

Lal, R., and J.P. Bruce. 1999. The potential of world cropland soils to sequester C and mitigate the greenhouse effect. Environ. Sci. Policy. 2: 77-185. 
Lal, R., and D. Ussiri. 2005. Carbon sequestration in reclaimed minesoils. Crit. Rev. Plant Sci. 24:151-165.

Mummey, D.L., P.D. Stahl, and J.S. Buyer. 2002. Soil microbiological properties 20 years after surface mine reclamation: Spatial analysis of reclaimed and undisturbed sites. Soil Biol. Biochem. 34:1717-1725.

Nyamadzawo, G., M.K. Shukla, and R. Lal. 2007. Spatial variability of total soil organic carbon and nitrogen stocks for some reclaimed minesoils of southeastern Ohio. Land. Degrad. Develop. 19:275-288.

Potthoff, R. F. (1966). Statistical aspects of the problem of biases in psychological tests. (Institute of Statistics Mimeo Series No. 479.) Chapel Hill: University of North Carolina, Department of Statistics.

Palmer, C.J., W.D. Smith, and B.L. Conkling. 2002. Development of a protocol for monitoring status and trends in forest soil carbon at a national level. Environ. Pollut. 116:209-219.

Shrestha, R.K., and R. Lal. 2006a. Enhancing carbon and nitrogen sequestration in reclaimed soils through organic amendments and chiseling. Soil Sci. Soc. Am. J. 73:1004-1011.

Shrestha, R.K., and R. Lal. 2006b. Ecosystem carbon budgeting and soil carbon sequestration in reclaimed minesoils. Environ. Int. 32:781-796.

Shukla, M.K., R. Lal, J. Underwood, and M.H. Ebinger. 2004. Physical and hydrological characteristics of reclaimed minesoils in Southeastern Ohio. Soil Sci. Soc. Am. J. 68:1352-1359.

Shukla, M.K., R. Lal, and M. H. Ebinger. 2005a. Physical and chemical properties of a minespoil eight years after reclamation in northeastern Ohio. Soil Sci. Soc. Am. J. 69:1288-1297.

Shukla, M. K. and R. Lal. 2005b. Soil organic carbon stocks for reclaimed minesoils in northeastern Ohio. Land Degrad. Develop. 16:377-386.

Shukla, M.K., R. Lal, and D. VanLeeuwen. 2007. Spatial variability of aggregate-associated carbon and nitrogen contents in the reclaimed minesoils of Eastern Ohio. Soil Sci. Soc. Am. J. 71:1748-1757.

Skousen, J., J. Sencindiver, K. Owens, and S. Hoover. 1998. Physical properties of minesoils in West Virginia and their influence on wastewater treatment. J. Environ. Qual. 27:633-639.

Snedecor, G.W., and W.G. Cochran. 1989. Statistical Methods. 8th Ed., Blackwell Publishing, Iowa State University Press, Ames, IA. 
Sperow, M. 2006. Carbon sequestration potential in reclaimed mine sites in seven east-central states. J. Environ. Qual. 35: 1428-1438.

Takata, Y., S. Funakawa, K. Akshalov, N. Ishida, and T. Kosaki. 2007. Spatial prediction of soil organic matter in northern Kazakhstan based on topographic and vegetation information. Soil Sci. Plant Nutr. 53:289-299.

Thomas, D. and I. Jansen. 1985. Soil development in coal mine spoils. J. Soil Water Conserv. 40: 439-442.

Townsend, P.A., D.P. Helmers, C.C. Kindon, B.E. McNeil, K.M. deBeurs, and K.N. Eshelman. 2009. Changes in the extent of surface mining and reclamation in the Central Appalachian detected using a 1976-2006 Landsat time series. Remote Sens. Environ. 113:62-72.

Uhland, R.E. 1949. Physical properties of soil as modified by crops and management. Soil. Sci. Soc. Am. Proc. 14:361-366.

Ussiri, D.A.N., R. Lal, and P.A. Jacinthe. 2006. Soil properties and carbon sequestration of afforested hay fields in reclaimed minesoils in Ohio. Soil Sci. Soc. Am. J. 71:1797-1806.

Yanai, J., A. Mishima, S. Funakawa, K. Akshalov, and T. Kosaki. 2005. Spatial variability of organic matter dynamics in the semi-arid croplands of Northern Kazakhstan. Soil Sci. Plant Nutr. 51:261-269. 

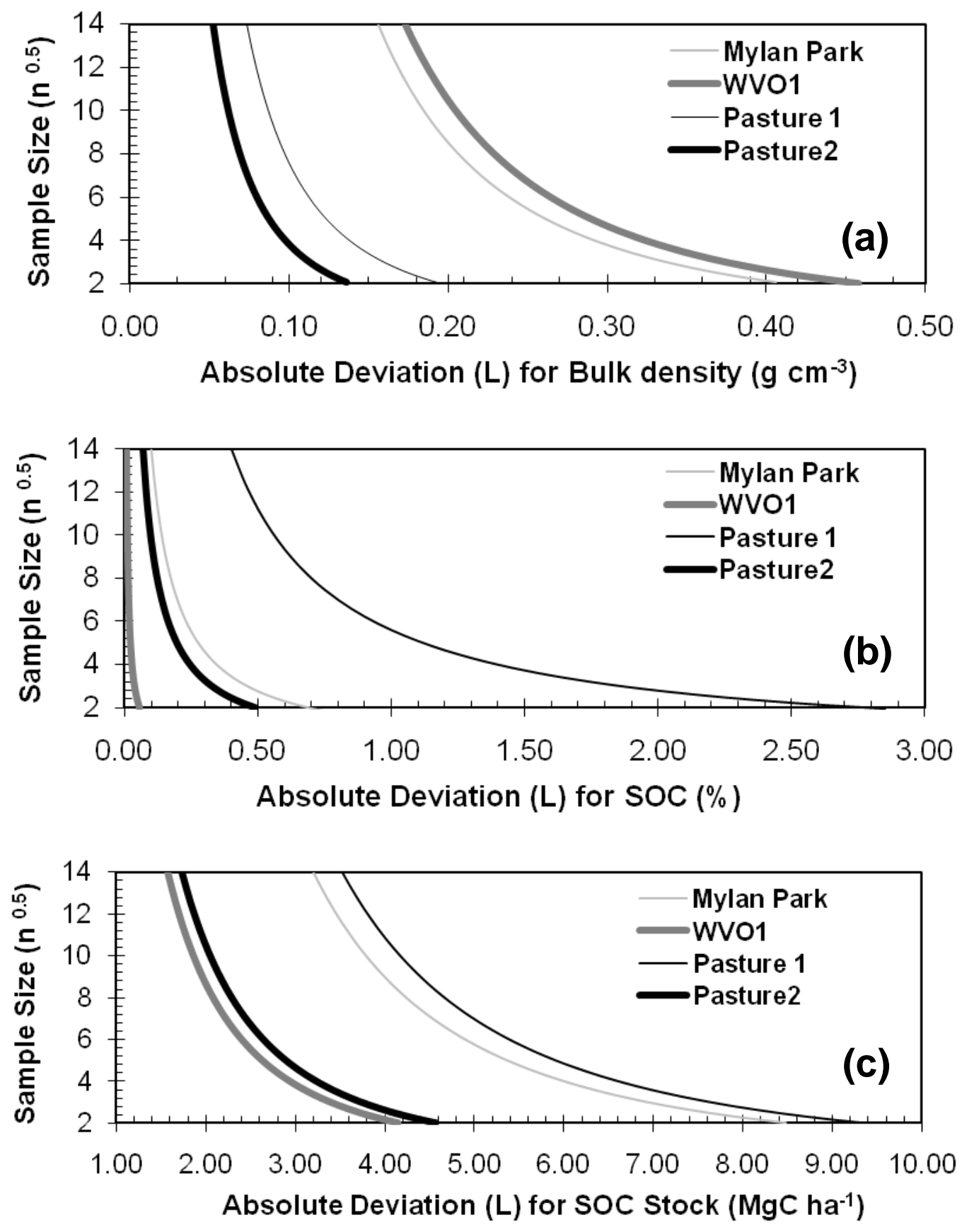

Figure 3-1: Sample size $\left(\hat{\mathrm{n}}^{0.5}\right)$ required to determine (a) soil bulk density $\left(\mathrm{g} \mathrm{cm}^{-3}\right)$, (b) SOC $(\mathrm{g} / \mathrm{kg})$, and (c) SOC stock $\left(\mathrm{Mg} \mathrm{C} \mathrm{ha}^{-1}\right)$ for selected absolute deviations (L); plotted using Equation 3. Range on y-axis is 4 to 196 samples. 

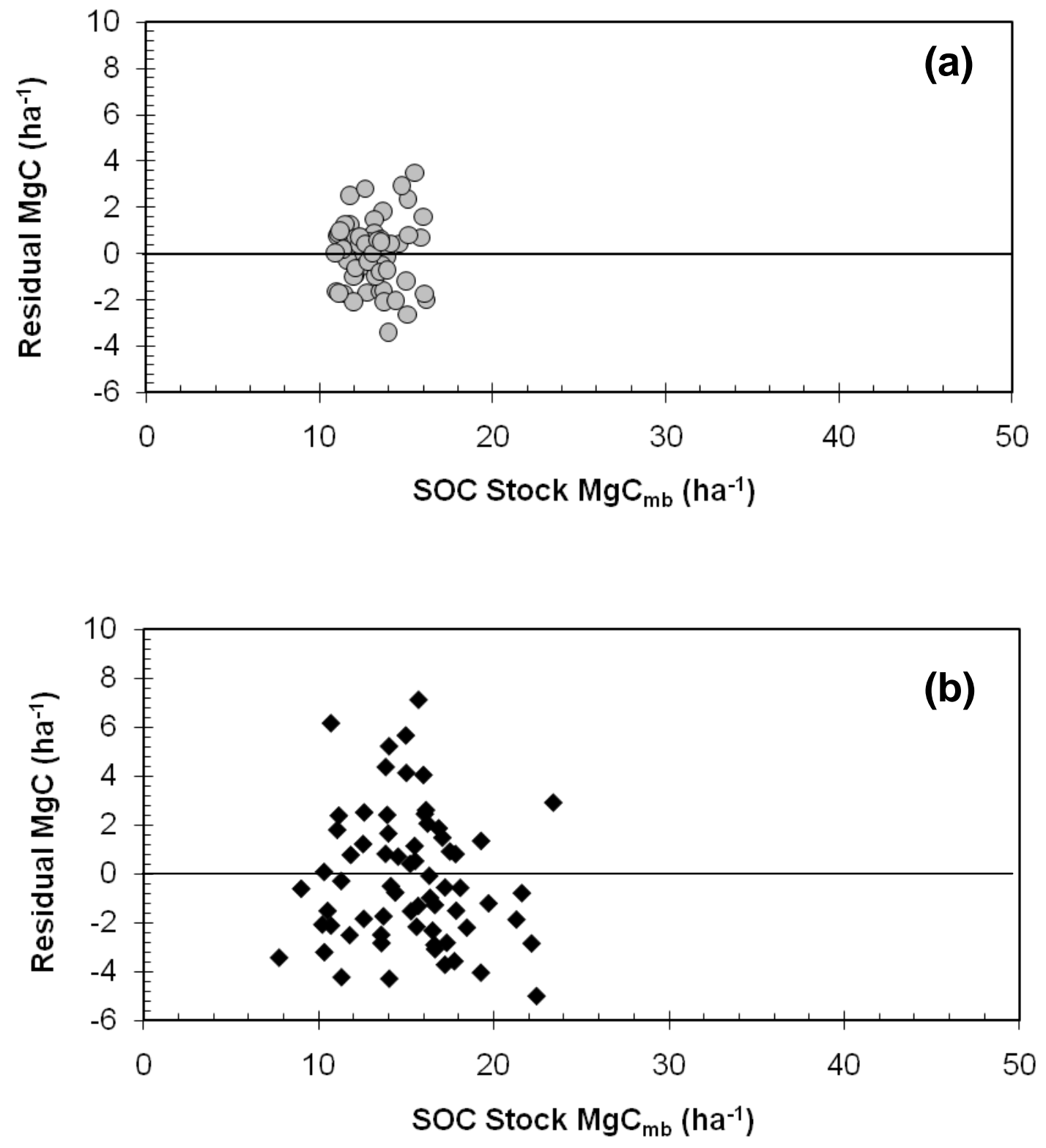

Figure 3-2: Plotted residuals as response factor to the fitted value (Eq. 2) for (a) WVO1, and (b) Mylan Park. 

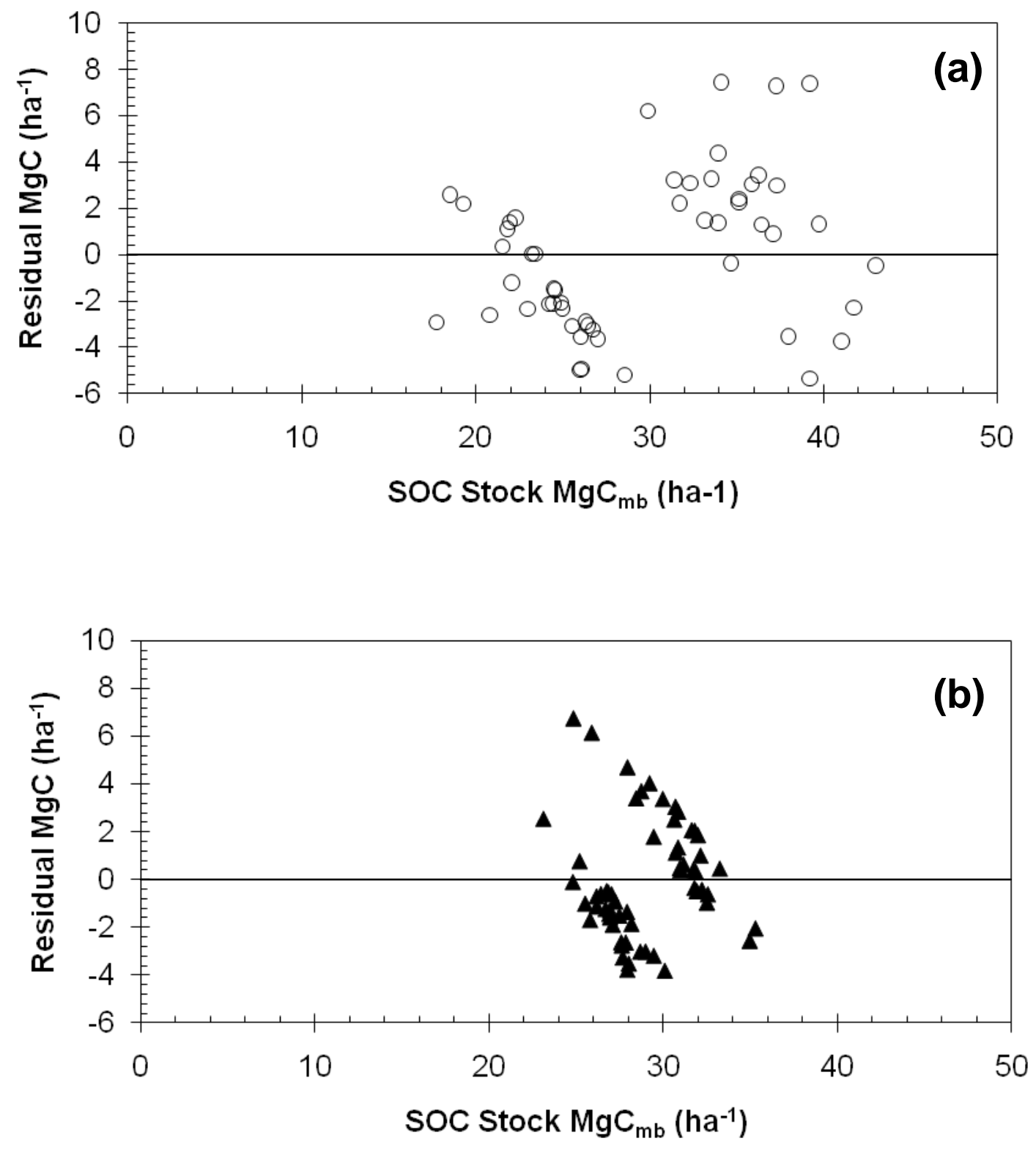

Figure 3-3: Plotted residuals as response factor to the fitted value (Eq. 2) for (a) Pasture 1, and (b) Pasture 2. 
Table 3-1: Summary statistics for SOC, $\rho$, and SOC stock at each reclaimed mine site (MP and WV01) and each managed hay field site (HF1 and HF2).

\begin{tabular}{|c|c|c|c|c|c|c|c|c|c|c|c|c|}
\hline \multirow{2}{*}{$\begin{array}{l}\text { Summary } \\
\text { Statistic }\end{array}$} & \multicolumn{4}{|c|}{$\mathrm{SOC}\left(\mathrm{g} \mathrm{kg}^{-1}\right)$} & \multicolumn{4}{|c|}{$\rho_{\mathrm{b}}\left(\mathrm{g} \mathrm{cm}^{-3}\right)$} & \multicolumn{4}{|c|}{ SOC Stock (Mg C ha-1) } \\
\hline & MP & WV01 & HF1 & HF2 & MP & WV01 & HF1 & HF2 & MP & WV01 & HF1 & HF2 \\
\hline Mean $^{1}$ & $21.73^{b}$ & $11.04^{\mathrm{c}}$ & $42.92^{\mathrm{a}}$ & $41.01^{\mathrm{a}}$ & $1.44^{\mathrm{b}}$ & $1.98^{\mathrm{a}}$ & $1.17^{\mathrm{c}}$ & $1.18^{\mathrm{c}}$ & $18.61^{\mathrm{b}}$ & $13.13^{\mathrm{c}}$ & $29.54^{\mathrm{a}}$ & $28.96^{\mathrm{a}}$ \\
\hline Median & 22.07 & 10.89 & 41.11 & 40.90 & 1.44 & 1.94 & 1.15 & 1.19 & 18.79 & 13.03 & 58.65 & 28.41 \\
\hline Variance & 35.64 & 2.74 & 147.54 & 25.84 & 0.09 & 0.11 & 0.02 & 0.01 & 37.79 & 9.06 & 45.82 & 10.98 \\
\hline CV $(\%)$ & 27.48 & 15.01 & 28.30 & 12.40 & 21.35 & 16.7 & 11.36 & 8.50 & 33.04 & 22.93 & 22.92 & 11.44 \\
\hline Maximum & 38.08 & 16.00 & 68.20 & 47.88 & 2.13 & 2.81 & 1.42 & 1.36 & 32.33 & 19.82 & 45.61 & 36.81 \\
\hline Minimum & 6.24 & 7.90 & 21.10 & 34.14 & 0.70 & 1.41 & 0.94 & 0.89 & 4.75 & 8.37 & 17.70 & 21.62 \\
\hline Skewness & -0.17 & 0.73 & 0.23 & 0.03 & 0.05 & 0.62 & 0.20 & -0.69 & 0.10 & 0.47 & 0.27 & 0.22 \\
\hline Kurtosis & 0.21 & 1.01 & -1.34 & -1.85 & -0.56 & 0.34 & -1.01 & 0.72 & -0.29 & -0.44 & -0.90 & -0.54 \\
\hline $\mathrm{n}$ & 74 & 64 & 60 & 60 & 74 & 64 & 60 & 60 & 74 & 64 & 60 & 60 \\
\hline
\end{tabular}

${ }^{1}$ means with same letter indicate no significance at $\alpha=0.05$ within a soil property.

MP = Mylan Park, HF1 = Hay Field 1, HF2 = Hay Field 2. 
Table 3-2: Minimum number of samples required ( $\hat{n})$ to detect a $10 \%$ change (from the mean) in SOC, $\rho b$, and SOC stock values at the 90,95 and $99 \%$ levels of confidence $(\alpha=0.10$, 0.05 and 0.01 , respectively)

\begin{tabular}{|c|c|c|c|c|c|c|c|c|c|c|c|c|}
\hline \multirow{2}{*}{$\alpha$ Level } & \multicolumn{4}{|c|}{ SOC $\left(\mathrm{g} \mathrm{kg}^{-1}\right)$} & \multicolumn{4}{|c|}{$\rho_{\mathrm{b}}\left(\mathrm{g} \mathrm{cm}^{-3}\right)$} & \multicolumn{4}{|c|}{ SOC Stock $\left(\mathrm{Mg} \mathrm{C} \mathrm{ha}^{-1}\right)$} \\
\hline & MP & WV01 & HF1 & HF2 & MP & WV01 & HF1 & $\mathrm{HF} 2$ & MP & WV01 & HF1 & $\mathrm{HF} 2$ \\
\hline$\alpha=0.10$ & 20 & 6 & 22 & 4 & 12 & 8 & 4 & 2 & 31 & 14 & 9 & 9 \\
\hline$\alpha=0.05$ & 29 & 9 & 30 & 6 & 17 & 11 & 6 & 3 & 43 & 20 & 12 & 13 \\
\hline$\alpha=0.01$ & 50 & 15 & 53 & 10 & 29 & 19 & 10 & 5 & 56 & 35 & 22 & 23 \\
\hline
\end{tabular}

MP = Mylan Park, HF1 = Hay Field 1, HF2 = Hay Field 2. 
Table 3-3: Regression parameters obtained for the straight line relationship between the mean-based $\left(\mathrm{Mg} \mathrm{C}_{\mathrm{mb}} \mathrm{ha}^{-1}\right)$ and point-based $\left(\mathrm{Mg} \mathrm{C}_{\mathrm{pb}} \mathrm{ha}^{-1}\right)$ SOC stock values and the statistical significance difference from the 1:1 line (mean-based versus point-based SOC stock values).

\begin{tabular}{lcccc}
\hline $\begin{array}{l}\text { Regression } \\
\text { Parameters }\end{array}$ & MP & WV01 & HF1 & HF2 \\
\hline Slope & $0.49^{*}$ & $0.46^{*}$ & $1.15^{*}$ & $0.80^{*}$ \\
Intercept & $5.74^{*}$ & $7.09^{*}$ & $3.96^{*}$ & $5.86^{*}$ \\
$\mathrm{R}^{2}$ & 0.56 & 0.49 & 0.84 & 0.54 \\
\hline
\end{tabular}

"Significant deviation of the estimated slope and intercept from that for the 1:1 line at the 95\% level of confidence. MP = Mylan Park, HF1 = Hay Field 1, HF2 = Hay Field 2. 


\title{
CHAPTER 4:
}

\section{Temporal Dynamics in Minesoil Surface Carbon Sequestration Due to Reclamation}

\section{Chronology}

\begin{abstract}
Reclaimed minesoils have well defined ages (time since reclamation), making them suitable for studying temporal changes in terrestrial carbon sequestration. The objective of this research was to assess the effect of time since reclamation on soil organic carbon (SOC) sequestration and related soil properties such as texture, bulk density and cation exchange capacity (CEC) in three West Virginia minesoils along a chronosequence. The minesoils surface $750 \mathrm{Mg} \mathrm{ha}^{-1}(0-6 \mathrm{~cm})$ was sampled at 1, 4, and 21 and, again at 2, 5, and 22 years post-reclamation. Average SOC stocks ( $\mathrm{Mg} \mathrm{C} \mathrm{ha}{ }^{-1}$ ) were highest in the oldest minesoils. Soil bulk density was highest and unrelated to SOC concentration in the youngest minesoil, reflecting recent compressive reclamation techniques. The CEC of older minesoils was influenced more by SOC than by clay, while the opposite was observed in younger minesoils. The relationship of SOC stock to time since reclamation was best described by a logarithmic diminishing returns model. Short-term (one year) SOC sequestration rates $\left(\mathrm{Mg} \mathrm{C} \mathrm{ha}^{-1} \mathrm{yr}^{-1}\right)$ were not appropriate for describing the change in SOC sequestration rate occurring along the chronosequence. When taken as the first derivative of the diminishing returns model, long-term SOC sequestration rates were shown to decline precipitously $(80 \%)$ in the first five years after reclamation. The model predicts that the surface $750 \mathrm{Mg} \mathrm{ha}^{-1}$ of minesoil will contain about $13.3 \mathrm{Mg} \mathrm{SOC} \mathrm{ha}^{-1}$ at $50 \mathrm{yr}$ after reclamation. About $75 \%$ of that SOC storage is predicted to be achieved in the first decade after reclamation.
\end{abstract}

Keywords: chronosequence, minesoil, soil organic carbon sequestration rate, bulk density, cation exchange capacity. 


\subsection{Introduction}

Time defines soil properties by influencing the duration of pedological processes, within a context of parent material, topography, climate, and biota (Jenny, 1941). When soils develop over different time periods, but under similar conditions of topography, vegetation, climate and parent materials, the soils are genetically related, forming a chronosequence (Harden, 1982). The study of soil chronosequences yields information about the rate and trend of pedological change and these soils are valuable tools in soil-geomorphic research (Pillans et al., 1997; Hugget, 1998). Numerous soil chronosequences have been used to study a wide variety of geochemical and pedogenic changes (Mellor, 1986; Litcher, 1998; White et al., 2005). Reclaimed minesoils are especially suitable for soil carbon (C) sequestration-chronosequence research due to their well-defined ages (time since reclamation), which allows calculation of rates and directions of change for $\mathrm{C}$ storage and related time-dependent processes.

Surface mining practices in the Appalachian region can drastically alter landscape patterns and often result in a deterioration of soil physical and chemical properties (Shukla et al., 2004). However, with the adoption of appropriate reclamation strategies and some time for soil formation, soil properties can improve, with significant sequestration of atmospheric C (Shukla et al., 2004; Ussiri et al., 2006). Estimates of C sequestration rates for the entire United States minesoil area range from 0.5 to $1.0 \mathrm{MgC} \mathrm{ha}^{-1} \mathrm{yr}^{-1}$ (Lal, 2004).

Soil organic matter (SOM) dynamics influence long-term sustainability of reclaimed ecosystems, linking pedological processes with vegetation development (Schwenke et al., 2000). Soil organic matter influences soil cation exchange capacity (CEC). In more weathered soils, several studies have shown that CEC is greatly influenced by SOM (Oorts et al., 2000; Steiner et al., 2008). The reported contribution of SOM to CEC varies widely, ranging from about 25 to 90\% of total CEC (Moody, et al. 1994; Stevenson, 1994; Kaiser et al., 2007).

During the initial post-reclamation period, reclaimed minesoils have low soil organic carbon (SOC) concentrations (Ussiri et al., 2006), but after 20 to 50 years, surface minesoil SOC can increase by 10 to 50\% (Hallberg et al., 1978; Akala and Lal, 2001; Shukla et al., 2004; Ussiri et al., 2006). Research has shown that net $\mathrm{C}$ gain following conversion of severely degraded land to agricultural or forest land could be as high as $0.25 \mathrm{Mg} \mathrm{C} \mathrm{ha}^{-1} \mathrm{yr}^{-1}$ (Lal and Bruce, 1999). Within 28 years of reclamation, minesoils in Ohio reclaimed to forest, hay and/or pasture developed SOC stocks comparable to those of undisturbed soils (Shrestha and Lal, 2007). 
Carbon sequestration is found by determining the SOC stock $\left(\mathrm{Mg} \mathrm{C} \mathrm{ha}^{-1}\right)$, which is calculated with SOC concentration, sampling depth, and bulk density (Akala and Lal, 2001). Determining SOC stocks in reclaimed minesoils is more complex than other 'undisturbed' soils because of the highly variable soil bulk density resulting from disturbances caused by the surface material mixing and heterogeneous surface compaction during the reclamation procedures.

The main objective of this study was to characterize the effect of time since reclamation on selected soil quality parameters (bulk density, CEC, electrical conductivity (EC), $\mathrm{pH}$ and texture), and especially SOC sequestration, in a chronosequence of reclaimed minesoils. A second objective was to assess the effect of time since reclamation on the relationships between measured soil properties and SOC sequestration in the chronosequence.

\subsection{Materials and Methods}

\subsubsection{Site Description}

In 2007, a minesoil chronosequence comprised of three minesoils was identified in Monongalia County ( $39^{\circ} 37^{\prime} 45^{\prime \prime} \mathrm{N}, 7^{\circ} 57^{\prime} 22^{\prime \prime} \mathrm{W}$ ), West Virginia. Time since reclamation ranged from 1 to 22 years (Table 4-1). The climate in this region is temperate, characterized by average winter and summer temperatures of $0^{\circ} \mathrm{C}$ and $22^{\circ} \mathrm{C}$, respectively, and an average seasonal snowfall of about $80 \mathrm{~cm}$. The $30-\mathrm{yr}$ average annual precipitation is $104 \mathrm{~cm}, 56 \%$ of which falls during the April to September growing season.

The selected minesoils were reclaimed to mixed grass-legume pastures. The predominant species found were orchardgrass (Dactylis glomerata), alfalfa (Medicago sativa), red clover (Trifolium pratense), white clover (Trifolium repens), timothy (Phleum pratense L.), tall fescue (Festuca arundinacea), and bird's foot trefoil (Lotus corniculatus). The sites were mined and reclaimed in similar manner (Table 1), according to the guidelines set by the 1977 Surface Coal Mining Reclamation Act, compacted and graded to pre-mining surrounding contours so as to merge uniformly with the existing topography. The reclaimed sites were owned, mined and reclaimed by the same company. At the time of the first sampling, in 2007, minesoil ages were 1, 4 and 21 years for the WV01, New Hill and Mylan Park sites, respectively. 


\subsubsection{Minesoil Sampling and Analysis}

Approximately 0.5 ha of each minesoil was sampled in early summer (May-June) of both 2007 and 2008, according to an irregular grid (Table 4-2). In 2007, each sampling point was georeferenced with a hand held GPS unit having a precision of $\pm 0.3 \mathrm{~m}$, so as to sample close to the same point in 2008. Visual assessment in 2008 revealed that the second set of 'spatially corresponding' sampling points were less than $0.6 \mathrm{~m}$ from the points sampled in 2007 .

The surface $6 \mathrm{~cm}$ depth increment was sampled for bulk density using a modified excavation method (Blake and Hartge, 1986). Briefly, the method consisted of placing a fine sheet of plastic inside the $12.5 \mathrm{~cm}$ diameter auger-excavated hole and filling the hole to meet the surface with gently compacted fine sand. A graduated cylinder was used to measure the volume of sand used. The "gravel-uncorrected" bulk density (BD) was calculated with that volume and the total mass of the excavated oven-dried $\left(104^{\circ} \mathrm{C}\right.$ for $\left.24 \mathrm{hr}\right)$ soil, while the "gravel-corrected" $\mathrm{BD}$ was calculated with that volume and the mass of excavated oven-dried material passing a 2 mm sieve. In 2007 only gravel-uncorrected BD was determined, but in 2008 both gravel corrected BD and gravel-uncorrected BD were found. Gravel (oven dried material not passing a $2 \mathrm{~mm}$ sieve) averaged less than $100 \mathrm{~kg} \mathrm{Mg}^{-1}$ minesoil at all sites, so the gravel-uncorrected BD was used in all calculations.

Five gram sub-samples of gravel-free soil were shaken with $10 \mathrm{~mL}$ of $2 \mathrm{M} \mathrm{HCl}$ to remove inorganic $\mathrm{C}$ before analyzing for SOC by dry combustion using a LECO Tru Spec CHN (St. Joseph, MI) analyzer. The SOC stocks for the surface $750 \mathrm{Mg}$ minesoil ha $^{-1}$ were calculated using the following equation:

$$
M g C\left(h a^{-1}\right)=\frac{\left(\operatorname{SOC}^{j} \times\left(\frac{1.25}{\rho_{b}^{j}}\right) \times d \times 10^{4} m^{2} h a^{-1}\right)}{0.001}
$$

where $j$ represents the sampling location within the study site, SOC is the soil organic carbon concentration $\left(\mathrm{kg} \mathrm{Mg}^{-1}\right), \rho_{b}$ is the measured $\mathrm{BD}\left(\mathrm{Mg} \mathrm{m}^{-3}\right)$, and $d$ is the sampling depth (m). The $750 \mathrm{Mg} \mathrm{ha}^{-1}$ results from taking $6 \mathrm{~cm}$ layer of minesoil with a BD of $1.25 \mathrm{Mg} \mathrm{m}^{-3}$ (mass equivalent). The average BD values from all sampling events, at all sites, were greater than 1.25 $\mathrm{Mg} \mathrm{m}^{-3}$, so use of this value results in minimal extrapolation of SOC concentrations to depths deeper than those sampled. 
To determine short- (one year) and long-term SOC sequestration rates $\left(\mathrm{Mg} \mathrm{C} \mathrm{ha}^{-1} \mathrm{yr}^{-1}\right)$ the following calculations were done: a) short-term SOC sequestration rates for each individual site, the 'site-based' SOC sequestration rates, were estimated using the site-average value for the change in SOC stock, calculated from the population of individual values generated at each spatially corresponding sampling point, using the samples taken one year apart (in 2007 and 2008) and; b) long-term SOC sequestration rates for the whole chronosequence, called 'chronosequence-based' SOC sequestration rates, were calculated as the first derivative of a plot of 'mass equivalent' SOC stock versus time using the site-average SOC stock values corresponding to the years since reclamation for the six individual site-sampling events. The fundamental assumption was that these minesoils form a chronosequence where all other soil forming factors (parent material, climate, vegetation and topography), and management history, were similar. These minesoils are distinguished only by time (time since reclamation).

Minesoil chemical properties were determined on samples collected in 2008. Cation exchange capacity was determined by the compulsive exchange method using $0.1 \mathrm{M} \mathrm{BaCl}_{2}$ (Sumner and Miller, 1996). Soil pH and EC were measured on 1:2.5 soil to water extracts (Rhoades, 1996). Minesoil particle-size distribution (texture) was determined using the pipette method after preprocessing the samples by removing organic matter with hydrogen peroxide, free iron oxides with dithionite-citrate-bicarbonate, and carbonates with $2 \mathrm{M} \mathrm{HCl}$, all to ensure dispersion of minesoil particles (Asamoa, 1973).

Statistical analysis was performed with SAS v 9.1.3 (SAS Institute, 1990). Minesoil properties were compared between sites and sampling years using ANOVA and Fisher's least significant difference (LSD) at the $95 \%$ level of confidence (probability of a greater $\mathrm{F} \leq 0.05$ ). Pearson linear correlation coefficients were calculated between soil variables. Multiple linear regression models were built to understand the effect of time since reclamation on minesoil properties and SOC sequestration patterns along the chronosequence.

\subsection{Results}

Average gravel-uncorrected BD values found in 2007 and 2008 were consistently highest at WV01, followed by Mylan Park, and lowest at New Hill (Table 4-3). Average SOC concentrations increased significantly $(p \leq 0.05)$ following the order WV01 < New Hill < Mylan Park, in both years (Table 4-4). The average increase in SOC concentration between the two 
sampling years was statistically significant $(\mathrm{p} \leq 0.05)$ at Mylan Park $(+21 \%)$ and New Hill $(+23$ \%). The 'mass equivalent' SOC stocks were significantly higher in 2008 than 2007 at Mylan Park and New Hill, while no difference was observed at WV01 (Table 4-5). Average SOC stocks, for 2007, decreased significantly $(p<0.05)$ following the order Mylan Park > New Hill > WV01, while in 2008 it followed the order Mylan Park $\approx$ New Hill > WV01. Site-based SOC sequestration rates $\left(\mathrm{Mg} \mathrm{C} \mathrm{ha}^{-1} \mathrm{yr}^{-1}\right)$ along the chronosequence followed the order: New Hill (2.1 $\pm 3.26) \approx$ Mylan Park $(2.0 \pm 3.12)>$ WV01 $(0.3 \pm 0.75)$. Coefficients of variation $(\mathrm{CV})$ for SOC concentration, minesoil BD and SOC stock ranged from 15 to 30, 13 to 21 and 20 to $40 \%$, respectively, across the two sampling events (Tables 4-3, 4-4 and 4-5). The CV for SOC concentration was lowest at WV01 (Table 4), while that for SOC stock was highest at Mylan Park (Table 4-4).

The proportion of primary minesoil particles found in the clay size fraction ranged between 155 and $180 \mathrm{~g} \mathrm{~kg}^{-1}$, decreasing significantly $(p<0.05)$ with minesoil age (WV01 > New Hill > Mylan Park) (Table 4-6). On average, sand concentrations ranged between 210 and $370 \mathrm{~g}$ $\mathrm{kg}^{-1}$, being greater in the younger minesoils (New Hill > WV01 > Mylan Park). The silt concentration was greatest in the oldest minesoil (Table 3-6). Variability within each site, for each component of texture, was similar (CV values between 9 and $16 \%$ ), except for the sand fraction at Mylan Park, which exhibited a CV of nearly $32 \%$.

Average site CEC values ranged from about 3 to about $12 \mathrm{cmol}_{\mathrm{c}} \mathrm{kg}^{-1}$, and increased significantly with minesoil age, following the order WV01 < New Hill < Mylan Park (Table 47). Minesoil EC behaved oppositely, ranging from 0.03 to $0.05 \mathrm{dS} \mathrm{m}^{-1}$, following the order WV01 > New Hill > Mylan Park. Average pH was higher in the oldest minesoil, Mylan Park, (Table 4-7). The within-site variability in these minesoil properties (Table 4-7) was greater for CEC (CV values from 16 to $20 \%$ ) and EC (CV values from 15 to $23 \%$ ) than for $\mathrm{pH}(\mathrm{CV}$ values between 6 and $12 \%$ ). There was little relationship between minesoil age and the variation in these properties (Table 4-7).

Statistically significant positive correlations were observed between SOC concentrations and minesoil CEC, clay and EC levels, within all three sites (Table 4-8). The older minesoils exhibited the greater correlation coefficients. Stronger correlations were observed between CEC and clay contents in the younger minesoils, though these two properties were significant and 
positively related within all sites (Table 4-8). Within-site SOC concentrations were unrelated to $\mathrm{BD}$ and $\mathrm{pH}$ values. The within-site SOC stocks were unrelated to $\mathrm{pH}$ in any minesoil, weakly positively related to EC in the older two minesoils, and positively and significantly related to SOC concentration, CEC, clay and BD values in all three minesoils (Table 4-8). Minesoil EC was significantly and positively related to SOC concentration, CEC, clay and SOC stock values, with somewhat greater correlation coefficients for older minesoils. Minesoil BD and pH values were not related to any other measured minesoil property (Table 4-8).

Multiple linear regression prediction models for CEC as a function of SOC and clay concentrations, for each of the minesoils (Table 4-9), explained 58 to $72 \%$ of the variation, with significantly higher $\mathrm{R}^{2}$ values for older minesoils. The SOC made the more statistically significant contribution to the models for CEC in the two older minesoils, while clay was more important in the youngest minesoil.

\subsection{Discussion}

The minesoil chronosequence selected for the study had similar site geology, overburden parent material (sandstone and shale), climate, mining method, and reclamation method. Time since reclamation was the major soil forming factor distinguishing the sites. The observed BD values were within the range reported for Appalachian minesoils (Akala and Lal, 2001; Shukla et al., 2004; Ussiri et al., 2006; Jacinthe and Lal, 2007; Chatterjee et al., 2009). In these minesoils, BD values are determined by reclamation processes, which in this study consisted of overburden backfilling, grading to the original contour, topsoil replacement, and grading again, all done so as to provide a surface environment compatible with plant establishment and subsequent growth (Jacinthe and Lal, 2007). The heavy machinery used during grading compacts the minesoil, often causing BD values higher than $1.60 \mathrm{Mg} \mathrm{m}^{-3}$ (Shukla et al., 2004; Chatterjee et al., 2009). In this minesoil chronosequence, the highest BD values were observed at WV01, probably the result of a lack of time for sufficient root exploration/remediation of the recent reclamation-induced compaction. The lowest BD values were found in the older minesoils (Table 4-3). Similar temporal effects on minesoil BD have been reported by Chatterjee et al (2009).

Other soil properties have been affected by time. Proportional declines in minesoil clay, with corresponding increases in silt or sand with time since reclamation are likely the result of 
continued weathering of coarse rock materials and erosion of detached, unstable clay particles as these minesoils aged (White et al., 2005). Significantly higher CEC in the older minesoils indicated development of a more complex surface exchange system able to retain more cations and/or nutrients, generating better chemical conditions supporting an environment favorable to biological processes.

Earlier findings on changes in soil chemical properties in chronosequences as a result of time-dependant pedological processes (e.g. weathering, organic matter accumulation) support this observation (White et al., 2005). Multiple regression analysis relating measured CEC to minesoil clay and SOC contents, for each location sampled in this study, revealed that the statistical significance of the regression coefficients for both clay and SOC changed with time since reclamation. In the younger minesoil, the regression coefficient for clay exhibited higher statistical significance than the coefficient for SOC while the opposite was observed for the older minesoils (Table 4-8). These findings are supported by those of Kaiser et al. (2007), who reported that the contribution of SOC towards CEC decreased with increasing clay content, and vice versa.

Two mechanisms may explain these observations. First, the surface-coating of clay particles by soil organic matter may mask clay surface charges (Kahle et al., 2002). Surficial interactions between clay and SOC result in stabilization of SOC by the formation of organomineral complexes, leading to its sequestration (Sollins et al., 1996; Six et al., 2002; Eusterhues et al., 2003). Second, the increased organic matter humification in older soils increases molecular complexity and increases the CEC. Studies on the molecular make up of SOC revealed that the older minesoil SOC contains more humified polyaromatic species with a higher degree of substitution by carboxylic, carbonyl and hydroxyl moieties (Chapter 5). Polyaromatic organic molecules with a higher degree of substitution around the aromatic nucleus are biochemically recalcitrant (Solomon et al., 2007). Both mechanisms explain the results observed in this study (Moody, et al., 1994; Parfitt et al., 1995; Oorts et al., 2000; Loveland and Webb, 2003; Kaiser et al., 2007).

Soil EC significantly decreased with time along the chronosequence, in agreement with previously reports by Chatterjee et al. (2009). The decrease in minesoil EC with time since reclamation is likely the result of loss of free salt with weathering. Minesoil EC was significantly lower than $1 \mathrm{dS} \mathrm{m}^{-1}$, the value critically limiting the growth of a number of plant species (Ussiri 
et al., 2006). Minesoil EC was significantly and positively related to SOC, clay, and CEC, as reported by others (Rhoades et al., 1976; Heiniger et al., 2003). The higher positive correlation coefficients between EC and SOC, clay or CEC observed for the older minesoils indicates that soil solution electrolyte levels were positively related to ion retention properties in these minesoils. Additionally, these relationships became more positive with time.

Minesoils have reportedly exhibited high variability in chemical and physical properties (Wilding and Drees, 1983; Gerke et al., 2001; Haering et al., 2005). Wilding's (1985) system defines high variability when the $\mathrm{CV}$ is greater than $35 \%$, moderate variability when the $\mathrm{CV}$ falls between 15 and $35 \%$, and low variability when the CV is less than $15 \%$. Using this system, SOC stock at Mylan Park is classified highly variable, while that for the other two minesoils in the studied chronosequence is classified as low to moderately variable. The SOC and BD values were moderately variable for all minesoils in the studied chronosequence. Soil texture, CEC, EC, and $\mathrm{pH}$ exhibited low to moderate variability, causing these disturbed soils to be ranked similar in their variation in these properties to non-altered soils.

When determining SOC stocks for a given volume of regolith, BD and SOC concentration are given equal weight. In this study, the young minesoil surface layer at WV01 exhibited a BD value so high that despite a low SOC concentration, the calculated SOC stock was greater (in both 2007 and 2008) than that for the surface layer at New Hill. To sample a soil mass equivalent to that taken from the surface $6 \mathrm{~cm}$ at WV01 (about $1200 \mathrm{Mg} \mathrm{ha}^{-1}$ ), would have required an extrapolation equivalent to a $50 \%$ increase in sampling depth (3 to $4 \mathrm{~cm}$ deeper depth) at both New Hill and Mylan Park. As minesoil SOC (and other minesoil properties) are strongly stratified, this was deemed unacceptable. The more conservative approach, limiting the equivalent soil mass to that sampled at the least dense site (New Hill), yielded the $750 \mathrm{Mg} \mathrm{ha}^{-1}$ (6 cm layer with a bulk density of $1.25 \mathrm{Mg} \mathrm{m}^{-3}$ ) value chosen here.

The SOC concentration, and the 'mass equivalent' SOC stock found in the surface 750 Mg of soil (Tables 4-4 and 4-5), increased with time since reclamation (WV01 < New Hill < Mylan Park), indicating that with similar soil forming conditions the time since reclamation significantly and positively influenced minesoil organic matter accumulation within a total of 22 years since reclamation. Further, though small, there were significant differences in SOC concentrations and stocks between minesoils differing only 3 years in time since reclamation. Overall, surface minesoil SOC stocks were lower in this chronosequence than those reported in 
similar chronosequence studies due to younger minesoils in this chronosequence (Akala and Lal, 2001; Ussiri et al., 2006; Amichev et al., 2008).

Regression of the six site-sampling event average values for 'mass equivalent' SOC stock versus time since reclamation (Figure 4-1) revealed a "diminishing returns" type of response, represented by a logarithmic equation, indicating that SOC stocks had increased most in the early years following reclamation along the chronosequence. Visual inspection suggests that the model under predicts chronosequence SOC stocks in the 4 to 15 years after reclamation time frame.

The short-term SOC sequestration rates, calculated from the difference between the 2007 and 2008 data sets from each site, were 0.3, 2.1 and $2.0 \mathrm{Mg} \mathrm{C} \mathrm{ha}^{-1} \mathrm{yr}^{-1}$ for WV01, New Hill and Mylan Park, respectively. These results indicate that SOC sequestration rates were initially slow for the youngest minesoil, but were more rapid in the older minesoils. The short-term rate results were contradicted by the long-term SOC sequestration rate versus time relationship shown in Figure 4-2. The Figure 4-2 relationship is the first derivative of the logarithmic relationship presented in Figure 4-1.

The first derivative relationship indicated that the 'soil mass equivalent' SOC sequestration rate followed a non-linear declining trend with time since reclamation, characterized by a steeper slope in the early years following reclamation, and did not capture the slow short-term rate ( $\left.0.3 \mathrm{Mg} \mathrm{Cha}^{-1} \mathrm{yr}^{-1}\right)$ observed for the WV01 site (Figure 4-2). Inspection of model fit in Figure 4-1 suggests that the true decline in SOC sequestration rate with time would be greater than that shown in Figure 4-2.

Other studies have reported that SOC sequestration rates are rapid in the initial years following reclamation, and then decline with time (Akala and Lal, 2001; Amichev et al., 2008). In this study, the modeled SOC sequestration rate decreased most rapidly ( $80 \%)$ over the first five years. In ten years, the model indicates that the sequestration rate would have declined by 90 $\%$, adding $0.23 \mathrm{MgC} \mathrm{ha}^{-1} \mathrm{yr}^{-1}$ to a stock estimated (from model shown in Figure 4-1) to about 9.6 Mg C ha ${ }^{-1}$. Diaz-Zorita and Grove (2002) used another diminishing returns model to estimate that 8 years of no-tillage crop production would be needed to fill about $90 \%$ of the carbon sequestration capacity of the surface layer of an agricultural soil near Lexington, Kentucky. The first derivative developed from this work (Figure 4-2) predicts that the SOC sequestration rate in the surface layer of these minesoils will be inconsequential $\left(<0.05 \mathrm{Mg} \mathrm{Cha}^{-1} \mathrm{yr}^{-1}\right)$ about 46 years after reclamation. 
Though there is a general understanding that the SOC sequestration versus time relationship (Figure 4-1) is nonlinear, there are few examples of models derived from real data. The SOC stock versus time model shown in Figure 4-1 predicts that the surface $750 \mathrm{Mg} \mathrm{ha}^{-1}$ of these minesoils will contain about $13.3 \mathrm{Mg} \mathrm{SOC} \mathrm{ha}^{-1}$ at $50 \mathrm{yr}$ after reclamation. About $90 \%$ of that SOC accumulation is predicted to have occurred $28 \mathrm{yr}$ after reclamation, and about $75 \%$ will have occurred within the first decade post-reclamation.

\subsection{Conclusion}

The work on this reclaimed minesoil chronosequence found temporal changes in SOC that were associated with changes in $\mathrm{CEC}, \mathrm{EC}$, texture, and $\mathrm{pH}$. The higher SOC, CEC and $\mathrm{pH}$ values, as well as the lower EC values, observed in the older minesoils indicate that these soils have likely become more favorable for vegetative growth and subsequent SOC sequestration. The CEC in the youngest minesoils was more related to mineral clay content than organic matter levels, the opposite of what was found for the older minesoils.

In the studied minesoil chronosequence, SOC and 'mass equivalent' SOC stocks were significantly higher in the older minesoils, indicating a positive influence of time on SOM dynamics under similar soil forming conditions. Short-term (one year) SOC sequestration rates were significantly higher in the older two minesoils, but did not reveal the true nature of the change in SOC sequestration rate occurring along the minesoil chronosequence. The long-term SOC sequestration rates, derived from the plot of SOC stock versus time since reclamation for the chronosequence, were greater early, falling precipitously in the first five years after reclamation. These results indicate that the greatest impact of these grassland minesoils, as regards sequestration of carbon, is realized in the first decade subsequent to reclamation. 


\section{References}

Amichev, B.Y., A.J. Burger, and J.A. Rodrigue. 2008. Carbon sequestration by forests and soils on minelands in the Midwestern and Appalachian coalfields of the US. Forest Ecol. Mang. 256:1949-1959.

Akala, V.A., and R. Lal. 2001. Soil organic pools and sequestration rates in reclaimed minesoils in Ohio. J. Environ. Qual. 30:2098-2104.

Asamoa, G.K. 1973. Particle size and free iron oxide distribution in some latosols and groundwater laterites of Ghana. Geoderma 10:285-297.

Blake, G.R., and K.H. Hartge, 1986, Bulk Density, in A. Klute, ed., Methods of Soil Analysis, Part I. Physical and Mineralogical Methods: Agronomy Monograph no. 9 (2nd ed.), pp.363-375.

Chatterjee, A., R. Lal, R.K. Shrestha, and D.A.N. Ussiri. 2009. Soil carbon pools of reclaimed minesoils under grass and forest land uses. Land Degrad. Dev. 20:300-307.

Diaz-Zorita, M., and J.H. Grove. 2002. Duration of tillage management affects carbon and phosphorus stratification in phosphatic Paleudalfs. Soil Till. Res. 66:165-174.

Eusterhues, K., C. Rumpel, M. Kleber, and I. Kogel-Knabner. 2003. Stabilization of soil organic matter by interaction with minerals as revealed by mineral dissolution and oxidative degradation. Org. Geochem. 34:1591-1600.

Gerke, H.H., E. Hangen, W. Schaaf, and R.F. Hutti. 2001. Spatial variability of potential water repellency in a lignitic mine soil afforested with Pinus nigra. Geoderma. 102:255-274.

Haering, K.C., W.L. Daniels, and J.M. Galbraith. 2005. Mapping and classification of southwest Virginia soils. Soil Sci. Soc. Am. J. 69:463-472.

Hallberg, G. R., N. C. Wollenhaupt, and G. A. Miller. 1978. A century of soil development in spoil derived from loess in Iowa. Soil Sci. Soc. Am. J. 42:339-343.

Harden, J.W. 1982. A quantitative index of soil development from field descriptions: Examples from a chronosequence in central California. Geoderma 28:1-28.

Heiniger, R.W., R.G. McBride, and D.E. Ckay. 2003. Using soil electrical conductivity to improve nutrient management. Agron. J. 95:508-519.

Hugget, R.J. 1998. Soil chronosequences, soil development, and soil evolution: A critical review. Catena 32:155-172. 
Jacinthe, P.A. and R. Lal. 2007. Carbon storage and minesoil properties in relation to topsoil application techniques. Soil Sci. Soc. Am. J. 71:1788-1791.

Jenny, H. 1941. Factors of Soil Formation. McGraw Hill. New York. p.241.

Kahle, M., M. Kleber, and R. Jahn. 2002. Predicting carbon content in illitic clay fractions from surface area, cation exchange capacity and dithionite extractable iron. Eur. J. Soil Sci. 53:639-644.

Kaiser, M., R.H. Ellerbrock, and H.H. Gerke. 2007. Cation exchange capacity and composition of soluble soil organic matter fractions. Soil Sci. Soc. Am. J. 72:1278-1285.

Lal, R. 2004. Agricultural activities and global carbon cycle. Nutr. Cycl. Agro-Ecosystems. 70:103-116.

Lal, R. and J.P. Bruce. 1999. The potential of world cropland soils to sequester C and mitigate the greenhouse effect. Environ. Sci. Policy. 2:77-185.

Litcher, J. 1998. Rates of weathering and chemical depletion in soils across a chronosequence of Lake Michigan sand dunes. Geoderma 85:255-282.

Loveland, P. and J. Webb. 2003. Is there a critical level of organic matter in the agricultural soils of temperate regions: A review. Soil Till. Res. 70:1-18.

Mellor, A. 1986. A micromorphological examination of two alpine soil chronosequences, southern Norway. Geoderma 39:41-57.

Moody, P. W., S.A. Yo, and R.L. Aitken. 1997. Soil organic carbon, permanganate fractions, and the chemical properties of acidic soils. Aust. J. Soil Res. 35:1301-1308.

Oorts, K., B. Vanlauwe, O.O. Cofie, N. Sangingna, and R. Merckx. 2000. Charge characteristics of soil organic matter fractions in a Ferric Lixisol under some multipurpose trees. Agroforestry Syst. 48:169.188.

Parfitt, R.L., D.J. Giltrap, and J.S. Whitton. 1995. Contribution of organic matter and clay minerals to the cation exchange capacity of soils. Commun. Soil Sci. Plan. 26:1343-1355.

Pillans, B. 1997. Soil development at snail's pace: Evidence from 6 Ma soil chronosequences on basalt in north Queensland, Australia. Geoderma 80:117-128.

Rhoades, J.D. 1996. Salinity, electrical conductivity and total dissolved salts. Methods of Soil Analysis, Part 3, Sparks DL (ed.). ASA and SSSA: Madison, WI.

Rhoades, J.D., P.A.C. Raats, and R.J. Prather. 1976. Effects of liquid-phase electrical conductivity on bulk soil electrical conductivity. Soil Sci. Soc. Am. J. 40:651-655. 
SAS Institute. 1990. SAS user's guide: Statistics 6th ed. Vol. 2. SAS Inst., Cary, NC.

Schwenke, G.D., L. Ayre, D.R. Mulligan, and L.C. Bell. 2000. Soil stripping and replacement for the rehabilitation of bauxite-mined land at Weipa. II. Soil organic matter dynamics in mine soil chronosequences. Aust. J. Soil Res. 38:371-393.

Shrestha, R. K., and R. Lal. 2007. Soil carbon and nitrogen in 28-year-old land uses in reclaimed coal mine soils of Ohio. J. Environ. Qual. 36:1775-1783.

Shukla, M. K., R. Lal, J. Underwood, and M. Ebinger. 2004. Physical and hydrological characteristics of reclaimed minesoils in southeastern Ohio. Soil Sci. Soc. Am. J. 68:1352-1359.

Six, J., R.T. Conant, E.A. Paul, and K. Paustian. 2002. Stabilization mechanisms of soil organic matter: Implications for C-saturation of soils. Plant Soil 241:155-176.

Solomon, D., J. Lehmann, J. Thies, T. Schafer, B. Liang, J. Kinyangi, E. Neves, J. Petersen, F. Luizao, and J. Skemstad. 2007. Molecular signature and biochemical recalcitrance of organic C in Amazonian dark earths. Geochim. Cosmochim. Ac. 71:2285-2298.

Stevenson, F. J. 1994. Humus Chemistry. Genesis, Composition, Reactions. Wiley and Sons: New York.

Steiner, C., B. Glaser, W.G. Teixeira, J. Lehmann, W.E.H. Blum, and W. Zech. 2008. Nitrogen retention and plant uptake in a highly weathered central Amazonian Ferralsol amended with compost and charcoal. J. Plant Nutr. Soil Sc. 171:893-899.

Sumner, M.E., and W. P. Miller. 1996. Cation exchange capacity, and exchange coefficients. In: D. L. Sparks (ed.) Methods of Soil Analysis. Part 2: Chemical properties. (3rd ed.) ASA, SSSA, CSSA, Madison, WI.

Ussiri, D., R. Lal, and P.A. Jacinthe. 2006. Soil properties and carbon sequestration in afforested pastures in reclaimed minesoils of Ohio. Soil Sci. Soc. Am. J.70:1797-1806.

White, A.F., M.S. Schultz, D.V. Vivit, A.E. Blum, D.A. Stonestrom, and J.W. Harden. 2005. Chemical weathering rates of a soil chronosequence on granitic alluvium: III. Hydrochemical evolution and contemporary solute fluxes and rates. Geochim. Cosmochim. Ac 69:1975-1996.

Wilding, L.P. 1985. Spatial variability: Its documentation, accommodation, and implication to soil surveys. p.166-194. In Shukla, M.K., R. Lal, and D. Vanleeuwen. 2007. Spatial 
variability of aggregate-associated carbon and nitrogen contents in the reclaimed minesoils of eastern Ohio. Soil Sci. Soc. Am. J. 71:1748-1751.

Wilding, L.P., and L.R. Drees. 1983. Spatial Variability and Pedology. In L.P. Wilding et al. (ed) Pedogenesis and Soil Taxonomy. I. Concepts and Interactions. Elsevier Science Publishers. B.V., Amsterdam. The Netherlands. 


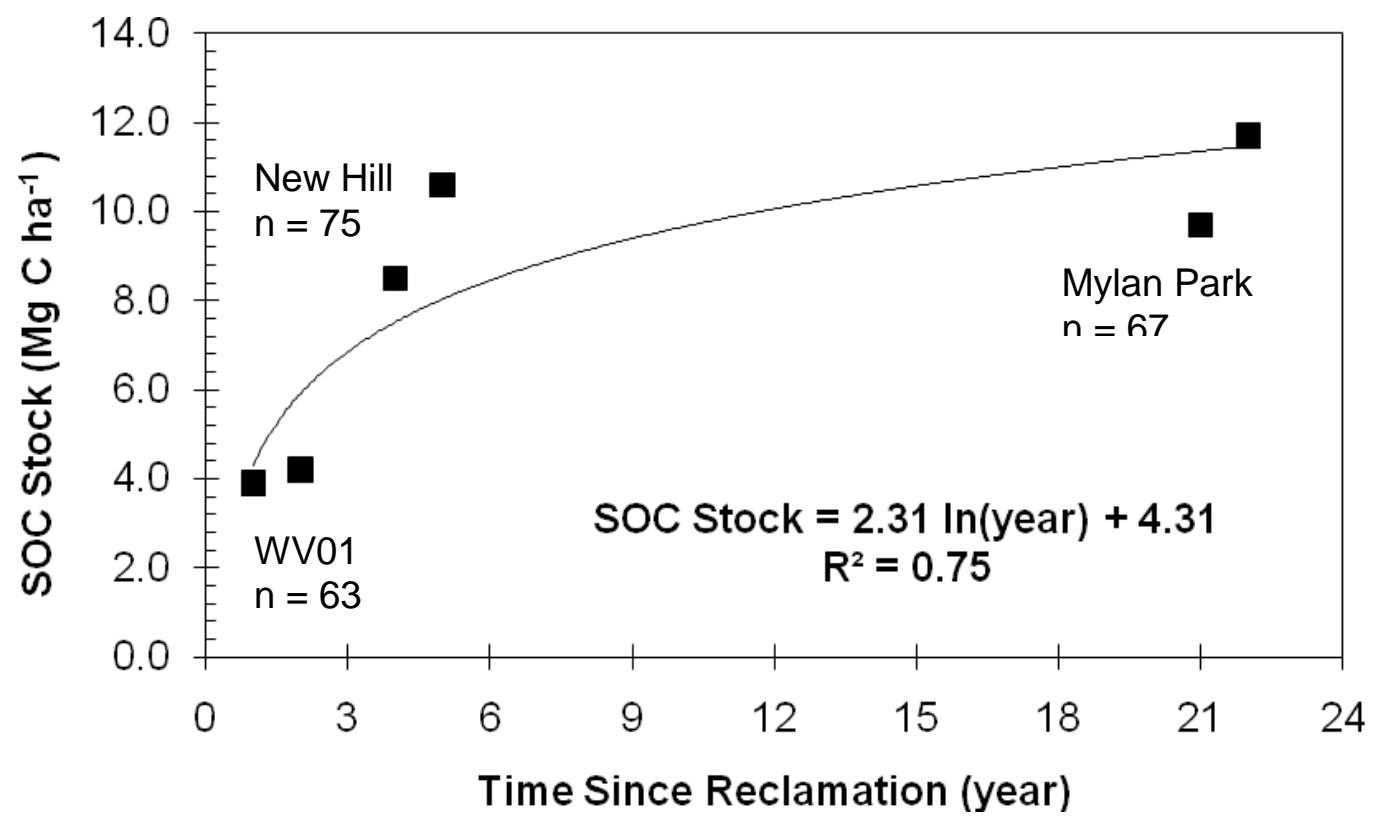

Figure 4-1: The relationship between SOC stock and time since reclamation for the minesoil chronosequence. 


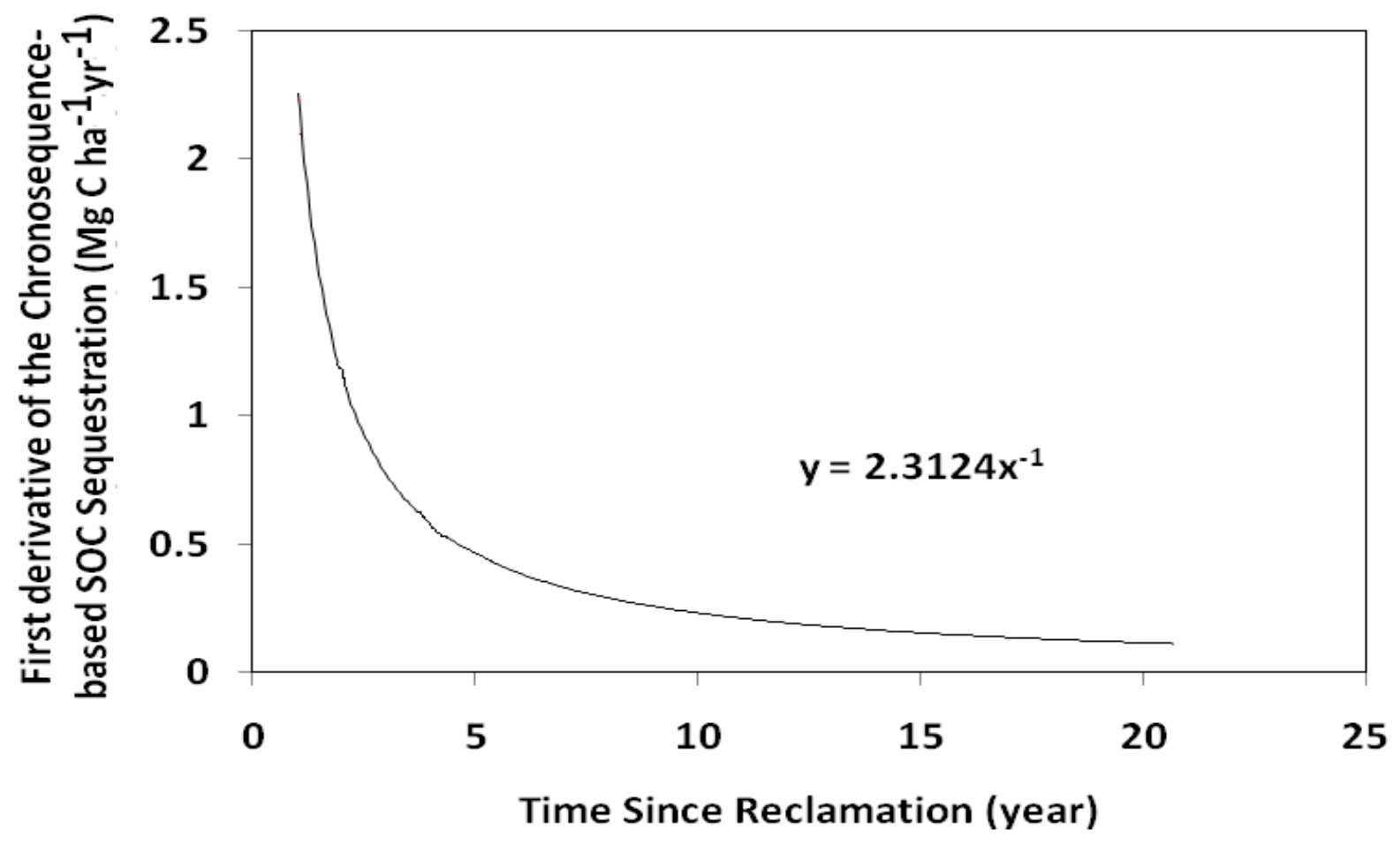

Figure 4-2: The relationship between the rate of SOC sequestration and the time since reclamation for the minesoil chronosequence. The relationship shown is the first derivative of the relationship shown in Figure 4-1. The time since reclamation is plotted for each of the six site-sampling events. 
Table 4-1. Characteristics of the reclaimed minesoil sites included in the study.

\begin{tabular}{|c|c|c|c|}
\hline Site Name & Mylan Park & New Hill & WV01 \\
\hline $\begin{array}{l}\text { Reclamation Age (years } \\
\text { since reclamation in 2007) }\end{array}$ & 21 & 4 & 1 \\
\hline Coal Type & \multicolumn{3}{|c|}{ - _ _ _ _ - - -Waynesburg - _ _ _ _ _ _ - } \\
\hline Method of Mining & \multicolumn{3}{|c|}{ - - - contour mining, front end loaders - - - } \\
\hline Overburden Type & \multicolumn{3}{|c|}{ - - -- 70-80\% sandstone, rest shale - - - - } \\
\hline Reclamation Method & \multicolumn{3}{|c|}{ - - - -backfilled, $7.5 \mathrm{~cm}$ topsoil, graded- - - - } \\
\hline $\begin{array}{l}\text { Post-Reclamation Land } \\
\text { Management Practice }\end{array}$ & \multicolumn{3}{|c|}{ - - - _ - - - grass-legume pasture - _ _ - - - } \\
\hline
\end{tabular}


Table 4-2: Grid dimensions and number of minesoil samples collected, by site.

\begin{tabular}{lcccc}
\hline Site Name & $\begin{array}{c}\text { Maximum } \\
\text { distance } \\
(\mathrm{m})\end{array}$ & $\begin{array}{c}\text { Minimum } \\
\text { distance } \\
(\mathrm{m})\end{array}$ & $\begin{array}{c}\text { Average } \\
\text { distance } \\
(\mathrm{m})\end{array}$ & $\begin{array}{c}\text { Number of } \\
\text { samples } \\
\text { collected }\end{array}$ \\
\hline Mylan Park & 6.2 & 5.5 & 5.9 & 74 \\
New Hill & 7.0 & 5.0 & 6.0 & 79 \\
WV01 & 12.0 & 4.0 & 8.0 & 64 \\
\hline
\end{tabular}


Table 4-3: Descriptive statistics for the minesoil bulk densities (BD) found in 2007 and 2008.

\begin{tabular}{|c|c|c|c|c|c|c|}
\hline \multirow{3}{*}{$\begin{array}{l}\text { Descriptive } \\
\text { Parameter }\end{array}$} & \multicolumn{6}{|c|}{$\ldots \ldots \ldots-\ldots$ - $\ldots$ - $\left(\mathrm{Mg} \mathrm{m}^{-3}\right) \ldots \ldots$} \\
\hline & \multicolumn{3}{|c|}{$-\ldots-\ldots 2007-\ldots-\ldots$} & \multicolumn{3}{|c|}{$-\ldots-\ldots 2008-\ldots$} \\
\hline & MP & $\mathrm{NH}$ & WV01 & MP & $\mathrm{NH}$ & WV01 \\
\hline Mean & $1.51^{b}$ & $1.31^{\mathrm{c}}$ & $2.06^{\mathrm{a}}$ & $1.47^{b}$ & $1.27^{\mathrm{c}}$ & $2.01^{\mathrm{a}}$ \\
\hline Median & 1.50 & 1.30 & 2.00 & 1.49 & 1.28 & 1.95 \\
\hline Standard Deviation & 0.30 & 0.18 & 0.33 & 0.31 & 0.18 & 0.33 \\
\hline $\mathrm{CV}(\%)$ & 20.0 & 13.5 & 16.0 & 21.0 & 14.2 & 16.5 \\
\hline Minimum & 0.80 & 0.90 & 1.51 & 2.19 & 0.85 & 2.82 \\
\hline Maximum & 2.22 & 1.96 & 2.89 & 0.75 & 1.94 & 1.44 \\
\hline Skewness & 0.12 & 0.44 & 0.69 & 0.10 & 0.34 & 0.60 \\
\hline Kurtosis & -0.59 & 1.65 & 0.33 & -0.58 & 1.66 & 0.25 \\
\hline
\end{tabular}


Table 4-4: Descriptive statistics for the SOC concentrations $\left(\mathrm{kg} \mathrm{Mg}^{-1}\right)$ found in 2007 and 2008.

\begin{tabular}{|c|c|c|c|c|c|c|}
\hline \multirow{2}{*}{$\begin{array}{l}\text { Descriptive } \\
\text { Parameter }\end{array}$} & \multicolumn{3}{|c|}{ - - - - - - - - 2007- } & \multicolumn{3}{|c|}{ 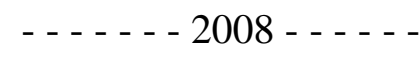 } \\
\hline & MP & $\mathrm{NH}$ & WV01 & MP & $\mathrm{NH}$ & WV01 \\
\hline Mean & $18.7^{\mathrm{a}}$ & $14.5^{\mathrm{b}}$ & $10.4^{\mathrm{c}}$ & $21.7^{\mathrm{a}}$ & $17.7^{\mathrm{b}}$ & $11.0^{\mathrm{c}}$ \\
\hline Median & 18.3 & 14.0 & 9.9 & 22.1 & 17.2 & 10.9 \\
\hline Standard Deviation & 5.1 & 4.3 & 1.9 & 6.0 & 4.6 & 1.7 \\
\hline $\mathrm{CV}(\%)$ & 27.0 & 29.6 & 18.1 & 27.5 & 25.8 & 15.0 \\
\hline Minimum & 6.8 & 4.3 & 8.8 & 6.2 & 6.2 & 7.9 \\
\hline Maximum & 29.1 & 26.1 & 19.1 & 38.1 & 29.5 & 16.0 \\
\hline Skewness & -0.08 & 0.10 & 2.50 & -0.17 & 0.33 & 0.73 \\
\hline Kurtosis & -0.29 & -0.08 & 7.43 & 0.21 & -0.04 & 1.01 \\
\hline
\end{tabular}

Mean values, for a given year, followed by the same letter are not significantly different $(\alpha=0.05) ; \mathrm{MP}=$ Mylan Park, $\mathrm{NH}=$ New Hill. 
Table 4-5: Descriptive statistics for the SOC stocks $\left(\mathrm{Mg} \mathrm{C} \mathrm{ha}^{-1}\right)$ found in 2007 and 2008.

\begin{tabular}{|c|c|c|c|c|c|c|}
\hline \multirow{3}{*}{$\begin{array}{l}\text { Descriptive } \\
\text { Parameter }\end{array}$} & \multicolumn{6}{|c|}{ - - - SOC Stock $\left(\mathrm{Mg} \mathrm{C} \mathrm{ha}^{-1}\right)$ - - - } \\
\hline & \multicolumn{3}{|c|}{$\ldots \ldots$} & \multicolumn{3}{|c|}{ - - - - - 2008 - - - - } \\
\hline & MP & $\mathrm{NH}$ & WV01 & MP & $\mathrm{NH}$ & WV01 \\
\hline Mean & $9.7^{\mathrm{a}}$ & $8.5^{\mathrm{b}}$ & $3.9^{\mathrm{c}}$ & $11.7^{\mathrm{a}}$ & $10.6^{\mathrm{a}}$ & $4.2^{\mathrm{b}}$ \\
\hline Median & 9.3 & 8.2 & 3.8 & 11.0 & 10.3 & 4.3 \\
\hline Standard Deviation & 3.8 & 2.9 & 1.0 & 4.6 & 3.2 & 0.9 \\
\hline $\mathrm{CV}(\%)$ & 38.5 & 33.8 & 25.0 & 39.2 & 29.8 & 20.5 \\
\hline Minimum & 4.2 & 2.5 & 2.5 & 3.6 & 3.6 & 2.4 \\
\hline Maximum & 22.4 & 16.8 & 8.8 & 24.3 & 20.8 & 6.2 \\
\hline Skewness & 0.97 & 0.55 & 2.15 & 0.88 & 0.66 & 0.29 \\
\hline Kurtosis & 0.99 & 0.39 & 8.90 & 0.70 & 0.72 & -0.12 \\
\hline
\end{tabular}


Table 4-6: Descriptive statistics for the minesoil particle size fractions (texture) found in 2008.

\begin{tabular}{|c|c|c|c|c|c|c|c|c|c|}
\hline \multirow{2}{*}{$\begin{array}{l}\text { Descriptive } \\
\text { Parameter }\end{array}$} & \multicolumn{3}{|c|}{$-\quad---$ - Clay $\left(\mathrm{g} \mathrm{kg}^{-1}\right)---$} & \multicolumn{3}{|c|}{ - - - - Sand $\left(\mathrm{g} \mathrm{kg}^{-1}\right)$ - - - } & \multicolumn{3}{|c|}{ - - - - Silt $\left(\mathrm{g} \mathrm{kg}^{-1}\right)$ - - - - } \\
\hline & MP & $\mathrm{NH}$ & WV01 & MP & $\mathrm{NH}$ & WV01 & MP & $\mathrm{NH}$ & WV01 \\
\hline Mean & $156^{\mathrm{c}}$ & $163^{b}$ & $177^{\mathrm{a}}$ & $208^{\mathrm{c}}$ & $367^{\mathrm{a}}$ & $295^{\mathrm{b}}$ & $635^{\mathrm{a}}$ & $577^{\mathrm{b}}$ & $529^{\mathrm{b}}$ \\
\hline Median & 156 & 166 & 178 & 208 & 368 & 306 & 636 & 581 & 519 \\
\hline Standard Deviation & 23.7 & 26.9 & 25.2 & 68.6 & 52.7 & 46.3 & 68.5 & 80.8 & 56.1 \\
\hline $\mathrm{CV}(\%)$ & 13.9 & 16.0 & 13.9 & 31.8 & 14.3 & 15.4 & 10.0 & 14.1 & 9.5 \\
\hline Minimum & 121 & 120 & 111 & 59 & 271 & 189 & 514 & 396 & 438 \\
\hline Maximum & 217 & 215 & 236 & 355 & 449 & 358 & 793 & 702 & 721 \\
\hline Skewness & 0.08 & 0.10 & -0.27 & 0.25 & -0.15 & -0.71 & 0.21 & -0.47 & 0.53 \\
\hline Kurtosis & -1.24 & -0.95 & 0.48 & -0.48 & -1.23 & -0.44 & -0.45 & -0.23 & -0.34 \\
\hline
\end{tabular}

Mean values followed by the same letter are not significantly different $(\alpha=0.05)$; MP $=$ Mylan Park, $\mathrm{NH}=$

New Hill. 
Table 4-7: Descriptive statistic for selected minesoil properties found in 2008.

\begin{tabular}{|c|c|c|c|c|c|c|c|c|c|}
\hline \multirow{2}{*}{$\begin{array}{l}\text { Descriptive } \\
\text { Parameter }\end{array}$} & \multicolumn{3}{|c|}{ - - CEC $\left(\mathrm{cmol}_{\mathrm{c}} \mathrm{kg}^{-1}\right)$ - - } & \multicolumn{3}{|c|}{$\ldots \ldots-\ldots$ pH $\ldots \ldots$} & \multicolumn{3}{|c|}{$\ldots$ - $\mathrm{EC}\left(\mathrm{dS} \mathrm{m}^{-1}\right) \ldots$} \\
\hline & MP & $\mathrm{NH}$ & WV01 & MP & $\mathrm{NH}$ & WV01 & MP & $\mathrm{NH}$ & WV01 \\
\hline Mean & $11.78^{\mathrm{a}}$ & $7.63^{b}$ & $2.82^{\mathrm{c}}$ & $7.43^{\mathrm{a}}$ & $6.67^{b}$ & $6.68^{\mathrm{b}}$ & $0.028^{\mathrm{c}}$ & $0.044^{\mathrm{b}}$ & $0.053^{\mathrm{a}}$ \\
\hline Median & 12.03 & 7.53 & 2.85 & 7.59 & 6.94 & 6.75 & 0.030 & 0.044 & 0.053 \\
\hline Standard Deviation & 2.35 & 1.38 & 0.06 & 0.47 & 0.72 & 0.11 & 0.007 & 0.001 & 0.001 \\
\hline $\mathrm{CV}(\%)$ & 19.9 & 18.0 & 15.6 & 6.4 & 10.8 & 11.5 & 22.9 & 15.4 & 19.2 \\
\hline Minimum & 16.06 & 4.99 & 1.47 & 5.93 & 5.37 & 5.47 & 0.040 & 0.030 & 0.030 \\
\hline Maximum & 6.43 & 10.46 & 3.85 & 7.94 & 7.93 & 8.06 & 0.015 & 0.057 & 0.070 \\
\hline Skewness & 9.64 & -0.01 & -0.48 & -1.64 & -0.39 & -0.02 & 0.02 & 0.04 & -0.68 \\
\hline Kurtosis & -0.41 & -0.74 & 1.03 & 2.85 & -0.74 & -1.29 & -0.32 & -0.48 & -0.25 \\
\hline
\end{tabular}


Table 4-8: Simple linear correlation coefficient (Pearson's r) between measured soil variables, for the 2008 sampling event.

\begin{tabular}{|c|c|c|c|c|c|c|c|}
\hline & $\begin{array}{l}\text { Minesoil } \\
\text { Name }\end{array}$ & $\begin{array}{c}\mathrm{SOC} \\
\mathrm{kg} \mathrm{Mg}^{-1}\end{array}$ & $\begin{array}{c}\mathrm{CEC} \\
\mathrm{cmol}_{\mathrm{c}} \mathrm{kg}^{-1}\end{array}$ & $\begin{array}{l}\text { Clay } \\
\mathrm{g} \mathrm{kg}^{-1}\end{array}$ & $\begin{array}{c}\mathrm{BD} \\
\mathrm{Mg} \mathrm{m}^{-3}\end{array}$ & $\begin{array}{l}\text { SOC Stock } \\
\left(\mathrm{Mg} \mathrm{C} \mathrm{ha}^{-1}\right)\end{array}$ & $\mathrm{pH}$ \\
\hline \multirow{3}{*}{$\begin{array}{l}\mathrm{CEC} \\
\left(\mathrm{cmol}_{\mathrm{c}} \mathrm{kg}^{-1}\right)\end{array}$} & Mylan Park & $0.84 *$ & & & & & \\
\hline & New Hill & $0.78 *$ & & & & & \\
\hline & WV01 & $0.63 *$ & & & & & \\
\hline \multirow{3}{*}{ Clay $\left(\mathrm{g} \mathrm{kg}^{-1}\right)$} & Mylan Park & $0.79 *$ & $0.57 *$ & & & & \\
\hline & New Hill & $0.79 *$ & $0.70^{*}$ & & & & \\
\hline & WV01 & $0.68 *$ & $0.76^{*}$ & & & & \\
\hline \multirow{3}{*}{$\mathrm{BD}\left(\mathrm{Mg} \mathrm{m}^{-3}\right)$} & Mylan Park & -0.15 & -0.09 & -0.19 & & & \\
\hline & New Hill & -0.09 & -0.04 & 0.00 & & & \\
\hline & WV01 & 0.02 & -0.08 & -0.14 & & & \\
\hline \multirow{3}{*}{$\begin{array}{l}\text { SOC Stock } \\
\left(\mathrm{Mg} \mathrm{C} \mathrm{ha}^{-1}\right)\end{array}$} & Mylan Park & $0.75 *$ & $0.60 *$ & $0.64 *$ & $-0.72 *$ & & \\
\hline & New Hill & $0.83 *$ & $0.62 *$ & $0.67 *$ & $-0.53 *$ & & \\
\hline & WV01 & $0.65 *$ & $0.49 *$ & $0.56^{*}$ & $-0.73 *$ & & \\
\hline \multirow{3}{*}{$\mathrm{pH}$} & Mylan Park & 0.13 & 0.00 & 0.21 & 0.02 & 0.09 & \\
\hline & New Hill & 0.10 & 0.22 & 0.10 & -0.14 & 0.17 & \\
\hline & WV01 & 0.16 & 0.09 & 0.02 & 0.12 & 0.02 & \\
\hline \multirow{3}{*}{$\mathrm{EC}\left(\mathrm{dS} \mathrm{m} \mathrm{m}^{-1}\right)$} & Mylan Park & $0.72 *$ & $0.73 *$ & $0.69 *$ & -0.04 & $0.50 *$ & 0.10 \\
\hline & New Hill & $0.60 *$ & $0.73^{*}$ & $0.65^{*}$ & -0.09 & $0.57 *$ & 0.15 \\
\hline & WV01 & $0.48 *$ & $0.67 *$ & $0.63 *$ & 0.06 & 0.29 & -0.04 \\
\hline
\end{tabular}

*Significant $(p \leq 0.05)$ relationship between the measured variates. 
Table 4-9: Cation exchange capacity $\left(\mathrm{cmol}_{\mathrm{c}} \mathrm{kg}^{-1}\right)$ regression prediction models based on clay $(\%)$ and SOC $(\mathrm{g} / \mathrm{kg})$ for 2008 sampling event.

\begin{tabular}{lccccc}
\hline \multirow{2}{*}{ Name } & \multicolumn{2}{c}{ Regression Model } & \multicolumn{3}{c}{ Probability of a greater F (p) } \\
\cline { 5 - 7 } & & & Clay & SOC & Model \\
\hline Mylan Park & CEC $=0.45$ SOC +0.27 Clay +6.13 & 0.72 & 0.06 & $<0.0001$ & $<0.0001$ \\
New Hill & CEC $=0.19$ SOC +0.12 Clay +2.32 & 0.62 & 0.15 & $<0.0001$ & $<0.0001$ \\
WV01 & CEC $=0.06$ SOC +0.01 Clay +0.25 & 0.58 & $<0.001$ & 0.09 & $<0.0001$ \\
\hline
\end{tabular}




\title{
CHAPTER 5:
}

Molecular Properties of Soil Organic Carbon (SOC): Indicators of SOC Sequestration in a Reclaimed Minesoil Chronosequence.

\begin{abstract}
The aim of this study was identify the effects of time since reclamation on changes in the soil organic carbon (SOC) molecular characteristics in a reclaimed minesoil chronosequence using several UV-Visible and synchronous fluorescence spectroscopic indices. The minesoils were sampled in 2007 and 2008 in the upper $6 \mathrm{~cm}$. In each minesoil a labile and a resistant SOC fraction were identified based on SOC molecular characteristics. The UV-Visible spectroscopic index $\varepsilon_{285}(\mathrm{mg} / \mathrm{L}), \mathrm{E}_{\mathrm{ET}}: \mathrm{E}_{\mathrm{Bz}}$ and the Kalbitz indices $\left(\mathrm{KI}_{470: 360}, \mathrm{KI}_{464: 397}\right)$ were significantly higher in the older minesoils which suggested that with increasing time since reclamation, the SOC molecules became more condensed, aromatic and humified with increased substitution by polar functional groups (-COOH, $=\mathrm{CO})$ in the aromatic nucleus. The UV-Visible index $\varepsilon_{285}(\mathrm{mg} / \mathrm{L})$ was more efficient to identify short-term (1 year) changes, only apparent in the older minesoils, in molecular properties. Along the chronosequence SOC molecular characteristics changed following a logarithmic trend. Strong positive relationships $\left(\mathrm{R}^{2}\right)$ between $\varepsilon_{285}(\mathrm{mg} / \mathrm{L}), \mathrm{KI}_{470: 360}, \mathrm{KI}_{464: 397}$ and SOC $\left(\mathrm{g} \mathrm{kg}^{-1}\right)$ were observed for all minesoils with significantly higher $\mathrm{R}^{2}$ values been found in the older minesoils. Strong positive relationships between the $\varepsilon_{285}$ and Kalbitz indices suggested that humification progressed via aromatization of SOC molecules. Significantly higher SOC $\left(\mathrm{g} \mathrm{kg}^{-1}\right)$ and presence of more humified and condensed aromatic species in the older minesoils suggested that these kinds of molecular characteristics lead to SOC-stabilization resulting in its preservation and sequestration in minesoils.
\end{abstract}

Keywords: Soil organic carbon, minesoils, spectroscopy, aromaticity, humification. 


\subsection{Introduction}

Soil organic matter (SOM) is a complex mixture of humic acid, fulvic acid, polyphenols, amino acids, ketones, esters and carbohydrates with highly variable molecular size, structure, polyelectrolytic characteristics and functional groups (Gu et al. 1996). Soil carbon sequestration depends on stability and preservation of SOM from mineralization loss. The stability of SOM is related to its molecular composition and structural characteristics; polyaromatic organic molecules with a higher degree of substitution in the aromatic nucleus are biochemically recalcitrant, leading to long term soil carbon sequestration (Gerasimovwicz and Bayler, 1985; Solomon et al., 2000, 2005, 2007).

Spectroscopic techniques provide information on the structural and compositional characteristics of complex organic molecules based on the intensity and position of different absorption bands. Various UV-Vis (Chin et al., 1994; Khorsin et al., 1997; Peuravori and Pihlaja 1997; Traina et al., 1999), fluorescence (Sensei et al., 1989, 1990; Baker, 2002; Swietlik and Sikorska, 2004) and Fourier Transform Infrared (FT-IR) spectroscopic techniques (Inbar et al., 1989; Haberhauer et al., 1998, 2000; Ellerbrock et al., 1999a, b; Gerzabeck et al., 2001) have been used to characterize SOM quality, source, decomposition patterns, extent and types of substitution by different functional groups, and degree of humification.

Reclaimed minesoils can sequester significant amounts of soil organic carbon (SOC) with adoption of appropriate reclamation strategies and increasing time since reclamation (Shukla et al., 2005; Jacinthe and Lal, 2007). Due to their well-defined age (time since reclamation), reclaimed minesoils are suitable for studying time-dependent pedogenic processes. The objective of this research was to determine the effect of time since reclamation on molecular characteristics of a "labile" and "recalcitrant" SOC fraction using spectroscopic methods in a reclaimed minesoil chronosequence. Our approach was to determine (i) the changes in SOC molecular characteristics, as revealed by various spectroscopic indices, with time since reclamation, (ii) the interrelationship of these indices and their relationship to SOC concentration, (iii) differences between the molecular properties of the labile and recalcitrant SOC fractions. 


\subsection{Materials and Methods}

A chronosequence comprising four reclaimed minesoils, were established in Monongalia County, near Morgantown ( $39^{\circ} 37^{\prime} 45^{\prime \prime} \mathrm{N}, 79^{\circ} 57^{\prime} 22^{\prime \prime} \mathrm{W}$ ), West Virginia (Table 5-1). The sites were owned, mined and reclaimed by the same company. During the time of the study (2007-2008) Mylan Park, New Hill, WVSK, and WVO1 were 22-21, 5-4, 4-3, and 2-1 year old respectively. Initial reclamation at WVSK was performed in 1998.

However in 2003, the upper soil strata was scraped and pushed back towards the high walls situated along the hind margin. This made the time since reclamation of WVSK between 4 and 5 years. Mines were reclaimed to pasture ecosystems following the guidelines of SMCRA, 1977. Mine sites were seeded with tall fescue (Festuca arundinacea), bird's foot trefoil (Lotus corniculatus), rye grass (Lolium canariense) and winter wheat (Triticeae aestivum). However, during soil sampling the predominant species found at Mylan park and New Hill sites were orchardgrass (Dactylis glomerata), alfalfa (Medicago sativa), and red clover (Trifolium pratense) with minor amounts of white clover (Trifolium repens), timothy (Phelum pratense L.), tall fescue, and bird's foot trefoil. At WVSK and WVO1 the dominant species were mostly grass and legumes.

\subsubsection{Soil Sampling and Analysis}

Soil samples were collected in 2007 and 2008 using site-specific $(7 * 5 \mathrm{~m})$ grids from 0-6 cm depth covering a 1-1.5 ha area during early summer (May-June). A set of twenty five representative subsamples, selected on the basis of their aerial distribution and range of total SOC $\left(\mathrm{g} \mathrm{kg}^{-1}\right)$, from each site were used in the spectroscopic studies. Five gram subsamples of gravel-free soil were shaken with $10 \mathrm{~mL}$ of $2 \mathrm{M} \mathrm{HCl}$ to remove inorganic $\mathrm{C}$ before analyzing for SOC by dry combustion (LECO TruSpec CHN, LECO Corp. St. Joseph, MI). Minesoil chemical properties were determined on samples collected in 2008. Cation exchange capacity (CEC) was determined by the compulsive exchange method using $0.1 \mathrm{M} \mathrm{BaCl}_{2}$ (Sumner and Miller, 1996). Soil $\mathrm{pH}$ and EC were measured on 1:2.5 soil to water extracts (Rhoades, 1996). Particle size analysis was done using the pipette method (Asamoa, 1973).

A two-step sequential extraction scheme was used to isolate a labile SOC fraction (Ghani et al., 2003) and a resistant SOC fraction (Fuentes et al., 2006). Briefly, the labile 
SOC fractions were extracted by shaking $10 \mathrm{~g}$ of soil with $40 \mathrm{~mL}$ of deionized water (DI) for 16 hours in a hot water bath at $80^{\circ} \mathrm{C}$. The resistant SOC fractions were extracted by shaking the soil residues, with $50 \mathrm{~mL}$ of $0.1 \mathrm{M} \mathrm{NaOH}$ for 24 hours in the dark at $22^{\circ} \mathrm{C}$. Both, DI- and $\mathrm{NaOH}$-extracts treated with DOWEX-50W ion exchange resin (BIO-RAD Laboratory) to remove interfering ions before spectroscopic analyses. Dissolved organic carbon (DOC, $\mathrm{mg} \mathrm{L}^{-1}$ ) was determined by a Sievers 5310C dissolved carbon analyzer.

Three each of UV-Vis and fluorescence spectroscopic indices were calculated based on absorption band ratios (Table 5-2). For the UV-Vis analyses, extracts were scanned from 200 to $700 \mathrm{~nm}$ on a UV-Visible spectrophotometer (Cary 50 Probe, Varian Inc., Walnut Creek, CA) to determine, $\mathrm{E}_{4}: \mathrm{E}_{6}$ (ratio of the absorption intensity at $465 \mathrm{~nm}$ and $665 \mathrm{~nm}$ ), $\mathrm{E}_{\mathrm{ET}}: \mathrm{E}_{\mathrm{Bz}}$, (ratio of the absorption intensity at $253 \mathrm{~nm}$ and: $220 \mathrm{~nm}$ ), $\varepsilon_{285}$ (absorption intensity at $\mathrm{E}_{285}$ normalized by dissolved organic carbon (DOC, $\left.\mathrm{mg} \mathrm{L}^{-1}\right)$ ). Synchronous fluorescence spectra were generated (Eclipse, Varian Inc., Walnut Creek, CA), to compute two indices, $\mathrm{KI}_{470: 360}$ (ratio of synchronous fluorescence intensity at $470 \mathrm{~nm}$ and $360 \mathrm{~nm}$ ); $\mathrm{KI}_{464: 397}$ (ratio of synchronous fluorescence intensity at $464 \mathrm{~nm}$ and $397 \mathrm{~nm}$ ) (Kalbitz and Geyer, 2001). Emission spectra were collected between the wavelengths 350 and $650 \mathrm{~nm}$, with an excitation wavelength of $240 \mathrm{~nm}$. The Zsolnay index for each minesoil for each SOC fraction and sampling year was calculated by dividing the integrated fluorescence intensities between $570-641 \mathrm{~nm}$ by 356-432 nm (Zsolnay et al., 1999).

FT-IR spectra (Equinox 55, Bruker Optics Inc., Billerica, MA) from 1000 - 4000 $\mathrm{cm}^{-1}$ were collected with a horizontal attenuated reflectance cell (HATR, Pike Technologies, Madison, WI), having a DGTS detector and ZnSe beamsplitter with $4 \mathrm{~cm}^{-1}$ resolution. Spectra were obtained in ambient conditions, scanned 100 times, averaged and corrected against the ambient air as background (Haberhauer et al., 2000). Relative absorbance intensities of certain diagnostic bands, 2916, 1728, 1651, 1512, 1435, 1388, and $1049 \mathrm{~cm}^{-1}$ were calculated. Relative absorbance (RA) of a particular band was calculated by dividing the peak height of that particular band by the sum of the peak heights of other bands (Haberhauer and Gerzabeck, 1999; Haberhauer et al., 2000). For example, relative absorbance of the $1049 \mathrm{~cm}^{-1}$ band $\left(\mathrm{RA}_{1049}\right)$ was calculated as:

$$
\mathrm{RA}_{1049}=\mathrm{A}_{1049} / \sum \mathrm{A}_{2916-1049 \mathrm{~cm}-1}
$$


Spectroscopic indices for each SOC fraction were compared between (i) the sampling events for each minesoil representing the short-term change and (ii) across the entire chronosequence representing long-term change by analysis of variance using the PROC GLM procedure in SAS 9.1.3 for Windows (SAS Institute, 2003). Regression analyses were performed between UV-Vis and fluorescence spectroscopic indices and total SOC $\left(\mathrm{g} \mathrm{kg}^{-1}\right)$ for each minesoil for both sampling events.

\subsection{Results and Discussion}

\subsubsection{UV-Visible Spectroscopy}

Average $\mathrm{E}_{4}: \mathrm{E}_{6}$ ratios decreased significantly along the chronosequence following the order WVO1 > WVSK $\approx$ New Hill > Mylan Park for both SOC fractions for both sampling events (Table 5-3a and 5-3b). The average $\mathrm{E}_{4}: \mathrm{E}_{6}$ ratios were significantly $(p<0.05)$ lower in the resistant than the labile $\mathrm{SOC}$ fractions. The magnitude of $\mathrm{E}_{4}: \mathrm{E}_{6}$ has been inversely related to molecular weight, degree of condensation and aromaticity (Kononova, 1966; Wang and Xing, 2005; Huang, et al., 2006). This suggests that with increasing time, the resistant SOC fractions of the older minesoils became more enriched in condensed aromatic species with smaller sizes.

Average $\mathrm{E}_{\mathrm{ET}}: \mathrm{E}_{\mathrm{Bz}}$ ratio increased significantly along the chronosequence as Mylan Park > New Hill > WVSK > WVO1 for the resistant SOC fractions for both sampling events (Table 5-3a and 5-3b). For the labile SOC fractions, the average $\mathrm{E}_{\mathrm{ET}} \mathrm{E}_{\mathrm{Bz}}$ ratio followed the order Mylan Park > New Hill $\approx$ WVSK > WVO1 for both sampling events. No significant differences were observed in the average $\mathrm{E}_{\mathrm{ET}}: \mathrm{E}_{\mathrm{Bz}}$ between the sampling events for any minesoil (Table 5-3a and 5-3b). The $\mathrm{E}_{\mathrm{ET}}: \mathrm{E}_{\mathrm{Bz}}$ ratio is strongly affected by polar functional groups and therefore reflects the extent of substitution in the benzene nucleus by hydroxyl, carbonyl, carboxyl and ester moieties (Khorsin et al., 1997; Fuentes et al., 2006). For unsubstituted benzene $\mathrm{E}_{\mathrm{ET}}$ : $\mathrm{E}_{\mathrm{Bz}}$ is low and increases with increasing content of polar groups (Kim and $\mathrm{Yu}, 2005$ ). The higher $\mathrm{E}_{\mathrm{ET}}: \mathrm{E}_{\mathrm{Bz}}$ ratios observed in resistant $\mathrm{SOC}$ fractions of older minesoils suggests that SOM had become more enriched in polar functional groups as the minesoils aged with higher degree of substitution observed for the resistant than for the labile SOC fractions. 
Average $\varepsilon_{285}(\mathrm{mg} / \mathrm{L})$ decreased significantly following the order Mylan Park > New Hill > WVSK > WVO1 for both SOC fractions in both sampling events (Table 5-3a and 5$3 b)$. The average $\varepsilon_{285}$ values were significantly higher in the resistant than the labile SOC fractions in all the minesoils for both years. The UV-Visible absorption features near 280 $\mathrm{nm}$ are characteristic of the $\pi \rightarrow \pi^{*}$ electronic transitions in a variety of aromatic species including phenols, benzoic acids, polyenes and polycyclic aromatic hydrocarbons with two or more rings (Traina et al., 1990; Chin et al., 1994). Therefore the molar absorptivity at $285 \mathrm{~nm}\left(\varepsilon_{285}\right)$ indicates the degree of aromaticity of SOC molecules and chemical reactivity of organic molecules (Chin et al., 1994; Stevenson et al., 1994; Durate et al., 2003; Huang et al., 2006). Higher average $\varepsilon_{285}(\mathrm{mg} / \mathrm{L})$ in the older minesoils suggests that SOC molecules become more aromatic with time, an observation supported by other studies (Kang et al., 2002), with the resistant SOC fractions being more aromatic than their labile counterpart.

\subsubsection{Fluorescence Spectroscopy}

Average $\mathrm{KI}_{464: 397}$ and $\mathrm{KI}_{464: 397}$ ratios decreased significantly following the order Mylan Park > New Hill > WVSK > WVO1 for both SOC fractions for both sampling events (Table 5-4a and 5-4b). The average Zsolnay index followed the order Mylan Park > New Hill > SK > WVO1 for the resistant SOC fractions in both years (Table 5-4a and 5-4b). For the labile SOC fractions, the average Zsolnay index varied as MP $>\mathrm{NH} \approx \mathrm{WVSK}>\mathrm{WVO} 1$ for both years (Table 4a-b). The shift in fluorescence peaks from the shorter to longer wavelengths indicates the presence of polycondensed aromatic species with extensive substitution and/or conjugated unsaturated systems with a high degree of resonance, characteristics of humified SOM (Sensei et al, 1989, 1991; Miano and Sensei, 1992; Kalbitz, 2001; Kalbitz and Geyer, 2001). Fluorescence peaks at higher wavelengths are indicative of highly conjugated double or triple bonds containing $\pi$-electrons. Electronwithdrawing moieties (carboxyl, carbonyl etc.) increases the wavelengths of excitation and emission, shifting the fluorescence peaks more towards lower energy levels (longer wavelengths). On the other hand, electron-donating moieties (hydroxyl, methoxyl, amino groups etc.) shift fluorescence peaks towards shorter wavelengths $(\sim 390 \mathrm{~nm})$ and indicate less-conjugated aromatic structures (Baker, 2002). Thus fluorescence indices with higher ratios are indicative of higher humification (Sensei et al., 1989; Kalbitz and Geyer, 2001; 
Kalbitz et al., 1999). Higher average fluorescence indices in older than younger minesoils suggest SOC molecules in the older minesoils were more humified.

No significant differences $(p<0.05)$ were observed in the average $\mathrm{E}_{4}: \mathrm{E}_{6}$ or $\mathrm{E}_{\mathrm{ET}}$ : $\mathrm{E}_{\mathrm{Bz}}$ ratios or any of the fluorescence indices between the sampling events within any minesite (Table 5-3 and 5-4). However, significantly higher average $\varepsilon_{285}(\mathrm{mg} / \mathrm{L})$ were observed at Mylan Park and New Hill in 2008 than 2007 which suggests that $\varepsilon_{285}(\mathrm{mg} / \mathrm{L})$ is more sensitive to short-term changes and thus better suited for identifying temporal changes in SOM dynamics. Spectroscopic indices showed a logarithmic trend along the chronosequence indicating that SOC molecules in the younger minesoils underwent various changes, probably attaining a more 'consistent' molecular configuration with increasing time since reclamation (Figure 5-1).

Significant $(p<0.01)$ positive relationships were observed between SOC $\left(\mathrm{g} \mathrm{kg}^{-1}\right)$

and several spectroscopic indices for both SOC fractions in sampling both years (Table 5-5 and 5-6). Significantly higher positive $\mathrm{R}^{2}$ values between $\mathrm{SOC}\left(\mathrm{g} \mathrm{kg}^{-1}\right)$ and the spectroscopic indices were observed for the older minesoils and for the resistant than the labile SOC fractions. This suggested that effect of molecular characteristics on SOC sequestration in this minesoil chronosequence became stronger as the minesoils aged. Significant positive relationships were found between $\varepsilon_{285}(\mathrm{mg} / \mathrm{L})$ and fluorescence indices, especially the Kalbitz indices. The spectroscopic indices provided complementary information on SOC molecular characteristics.

Distinguishable groupings, representing each reclaimed minesoil, were observed when some these spectroscopic indices were combined on ternary diagrams with total SOC $\left(\mathrm{g} \mathrm{kg}^{-1}\right)$ as the response variable (Figure 5-2). This suggested that these spectroscopic indices provide important clues to identify temporal changes in SOM "types" in terms of their molecular characteristics and can be used to distinguish minesoil with different time since reclamation.

\subsubsection{FTIR-ATR Spectroscopy}

Seven absorption bands were identified for each minesoil: a broad band between $3600-3200 \mathrm{~cm}^{-1}$ corresponding to hydrogen-bonded O-H stretching vibrations of hydroxyl $(\mathrm{OH})$ groups fund in alcohols, phenols and organic acids, and stretching from hydrogen- 
bonded amines and amide groups; a peak at 2930-2920 $\mathrm{cm}^{-1}$ arising from asymmetric and symmetric C-H stretching vibrations of aliphatic methyl and methylene groups $\left(\mathrm{CH}_{3}\right.$ and $\mathrm{CH}_{2}$ ) including lipid chains; a well pronounced peak at $1730 \mathrm{~cm}^{-1}$ due to $\mathrm{C}=\mathrm{O}$ stretching of carboxyl groups; a broad band at $1660-1650 \mathrm{~cm}^{-1}$ produced mainly by aromatic $\mathrm{C}=\mathrm{C}$ and to a smaller extent by conjugated carbonyl groups such as quinones and ketonic acids; a peak at $1512 \mathrm{~cm}^{-1}$ representing aromatic carbonyl bands; two peaks between $1460-1390 \mathrm{~cm}^{-1}$ corresponding to several groups such as $\mathrm{CH}_{3}, \mathrm{OH}$ of phenols; $\mathrm{COO}-$ and/or substituted aromatic rings; and a sharp peak at $1049 \mathrm{~cm}^{-1}$ for C-O stretching of polysaccharides (Stone et al., 2001; Ellerbrock and Gerke, 2004; Solomon et al., 2005). Mylan Park, New Hill and SK had similar spectral patterns indicating no qualitative differences between SOC molecules at these minesoils (Figure 5-3a). At WVO1, however, no prominent absorbance features at 1388 and $1435 \mathrm{~cm}^{-1}$ were observed indicating a lack of substituted aromatic species in these younger minesoils. These spectra, however, differed significantly in the relative absorbance intensities of certain bands (Fig. 5-3b). Relative absorbance bands representative of aliphatic-C $\left(2916 \mathrm{~cm}^{-1}\right)$, carboxyl-C $\left(1728 \mathrm{~cm}^{-1}\right)$, aromatic-C $\left(1651 \mathrm{~cm}^{-1}\right)$, carbonyl-C $\left(1512 \mathrm{~cm}^{-1}\right)$ and polysaccharide-C $\left(1049 \mathrm{~cm}^{-1}\right)$ respectively. The most significant differences were observed for the polysaccharide band which decreased significantly following the order WVO1 $>$ SK $>$ New Hill $\approx$ Mylan Park indicating higher proportions of polysaccharides in the younger than the older minesoils.. Relative proportions of the carbonyl-C and aromatic-C decreased significantly following the order Mylan Park > New Hill > SK > WVO1 while aliphatic-C decreased following the order WVO1 $>$ Mylan Park $\approx$ New Hill $\approx \mathrm{SK}$. This suggests that SOM in older minesoils were mostly aromatic type with higher substitution by quinones and ketonic moieties while in younger minesoil it was mostly aliphatic. Carboxyl-C decreased significantly as Mylan Park $>$ New Hill > SK > WVO1 indicating higher reactivity of SOM in older minesoils.

\subsection{Conclusion}

The older minesoils had more aromatic and humified SOC with significantly higher proportions of reactive functional groups. At each minesoil, SOC was comprised of a labile and a resistant fraction, with the later characterized by more aromatic and humified molecules. Molecular characteristics were related to total SOC $\left(\mathrm{g} \mathrm{kg}^{-1}\right)$ at each minesite with 
stronger relationships observed for the older minesoils. This indicated that SOC dynamics were influenced by the molecular characteristics, becoming more apparent as the minesoils aged. Along this minesoil chronosequence, the SOC molecular characteristics changed following a logarithmic pattern. The UV-Visible index, $\varepsilon_{285}(\mathrm{mg} / \mathrm{L})$ was more sensitive to short-term changes (1-year) in molecular properties than the other indices used in this study. Strong interrelationships between $\varepsilon_{285}(\mathrm{mg} / \mathrm{L})$ and the Kalbitz indices indicated that humification processes progressed with aromatization of the molecules.

Overall, this study showed that UV-Visible and fluorescence spectroscopic methods could be used as efficient means to illustrate differences in SOC molecular characteristics in reclaimed minesoils distinguished by times since reclamation, which in turn can be linked with concepts of SOC sequestration in these disturbed soils. 


\section{References}

Asamoa, G.K. 1973. Particle size and free iron oxide distribution in some latosols and groundwater laterites of Ghana. Geoderma 10:285-297.

Baker, A. 2002. Fluorescence properties of some farm wastes: implications for water quality monitoring. Water Res. 36 189-195.

Chin, Y.P., G. Alken, E. O'Loughlln. 1994. Molecular weight, polydispersity, and spectroscopic properties of aquatic humic substances. Environ. Sci. Technol, 28:1853-1858.

Durate, R.M.B.O., E.B.H. Santos and A.C. Durate. 2003. Spectroscopic characteristics of ultrafiltration fractions of fulvic and humic acids isolated from eucalyptus bleached Kraft pulp mill effluent. Water Res. 37:4073-4080.

Ellerbrock, R.H., and H.H. Gerke. 2004. Characterizing organic matter of soil aggregate coatings and biopore by Fourier transform infrared spectroscopy. Eur. J. Soil Sci. 55:219-228.

Ellerbrock, R.H., A. Hohn, and J. Rogasik. 1999a. Functional analysis of soil organic matter as affected by long-term manurial treatment. Eur. J. Soil Sci. 50:65-71.

Ellerbrock, R.H., A. Hohn, and H.H. Gerke. 1999b. Characterization of soil organic matter from a sandy soil in relation to management practice using FT-IR spectroscopy. Plant Soil. 213:55-61.

Fuentes, M., G. Gonzales-Gaitano, and J.M Garcia-Mina. 2006. The usefulness of UVvisible and fluorescence spectroscopies to study the chemical nature of humic substances from soils and composts. Org. Geochem. 37:1949-1959.

Gerasimovwicz, W.V. and D.F. Bayler. 1985. Carbon-13 CPMAS NMR and FTIR spectroscopic studies of humic acids. Soil Sci. 139:270-278.

Gerzabek, M.H., G. Habenhauer, and H. Kirchmann. 2001. Soil organic matter pools and carbon-13 natural abundances in particle-size fractions of a long-term agricultural field experiment receiving organic amendments. Soil Sci. Soc. Am. J. 65:352-358.

Ghani, A., M. Dexter, and K.W. Perrot. 2003. Hot-water extractable carbon in soils: A sensitive measurement for determining fertilization, grazing and cultivation. Soil Biol. Biochem. 35:1231-1243. 
Gu, B., T. Mehlhorn, L. Liang, and J.F. McCarthy, 1996. Competitive adsorpton, displacement, and transport of organic matter on iron oxide: I. Competitive adsorption. Geochim. Cosmochim. Ac. 60:1943-1950.

Haberhauer, G., B. Rafferty, F. Strebl, and M.H. Gerzabek. 1998. Comparison of the composition of forest soil litter derived from different sites at various decompositional stages using FTIR- spectroscopy. Geoderma 83:331-342.

Haberhauer, G and M.H. Gerzabek. 1999. Drift and transmission FT-IR spectroscopoy for forest soils: An approach to determine decomposition processes of forest litters. Vib. Spectrosc. 19:413-417.

Haberhauer, G., B. Feigl, M.H. Gerzabeck, and C. Cerri. 2000. FT-IR spectroscopy of organic matter in tropical soils: Changes induced through deforestation. Appl. Spectrosc. 54:221-224.

Hautala K., J. Peuravuori, and K. Pihlaja. 2000. Measurement of aquatic humus content by spectroscopic analyses. Water Res. 34:246-58.

Huang, G.F., Q.T. Wu, J.W.C. Wong, and B.B. Nagar. 2006. Transformation of organic matter during co-composting of pig manure with sawdust. Bioresource Technol. 97:1834-1842.

Inbar, Y., Y. Chen, and Y. Hadar. 1989. Solid-state carbon-13 nuclear magnetic resonance and infrared spectroscopy of composted organic matter. Soil Sci. Soc. Am. J. 53:1695-1701.

Jacinthe, P.A. and R. Lal. 2007. Carbon storage and minesoil properties in relation to topsoil application techniques. Soil Sci. Soc. Am. J. 71:1788-1791.

Kalbitz, K., W. Geyer, and S. Geyer. 1999. Spectroscopic properties of dissolved humic substance - A reflection of the landuse history in the fen area. Biogeochemistry. 47:219-238.

Kalbitz, K. 2001. Properties of organic matter in soil solution in a German fen area as dependent of landuse and depth. Geoderma. 104:203-214.

Kang, K.H., H.S. Shin, and H. Park. 2002. Characterization of humic substances in landfill leachates with different landfill ages and its implications. Water Res. 36:4023-4032.

Khorsin, G. Y., C.W. Li, and M.M. Benjamin. 1997. Monitoring the properties of natural 
organic matter through UV spectroscopy: A consistent theory. Water Res. 31:17871795.

Kim, H.C. and Y. M.J. 2005. Characterization of natural organic matter in conventional water treatment processes for selection of treatment processes focused on DBPs control. Water Res. 39:4779-4789.

Kononova, M.M. 1966. Soil Organic Matter. $2^{\text {nd }}$ ed. Permagon Press, Oxford. pp. 404.

Miano, T.M. and N. Senesi. 1992. Synchronous excitation fluorescence spectroscopy applied to soil humic substances chemistry. Sci. Total Environ. 117:41-51.

Peuravuori, J., R. Koivikko, and K. Pihlaja. 2002. Characterization, differentiation and classification of aquatic humic matter separated with different sorbents: Synchronous scanning fluorescence spectroscopy. Water Res. 36:4552-4562.

Rhoades, J.D. 1996. Salinity, electrical conductivity and total dissolved salts. In Methods of Soil Analysis, Part 3, Sparks DL (ed.). ASA and SSSA: Madison, WI.

Senesi, N., T.M. Miano, M.R. Provenzano, and G. Brunetti. 1989. Spectroscopic and compositional comparative characterization of I.H.S.S. reference and standard fulvic and humic acids of various origin. Sci. Total Environ. 81:143-156.

Senesi, N., 1990. Molecular and quantitative aspects of the chemistry of fulvic acid and its interactions with metal ions and organic chemicals. Part 2. The fluorescence spectroscopy approach. Analit. Chim. Acta. 232:7-106.

Senesi, N., T.M. Miano, M.R. Provenzano, and G. Brunetti. 1991. Characterization, differentiation, and classification of humic substances by fluorescence spectroscopy. Soil Sci. 152:259-271.

Shukla, M.K., R. Lal, and M.H. Ebinger. 2005. Physical and chemical properties of a minespoil eight years after reclamation in northeastern Ohio. Soil Sci. Soc. Am. J. 69:1288-1297.

Solomon, D., J. Lehmann, J. Thies, T. Schafer, B. Liang, J. Kinyangi, E. Neves, J. Petersen, F. Luizao, and J. Skemstad. 2007. Molecular signature and biochemical recalcitrance of organic $\mathrm{C}$ in Amazonian dark earths. Geochim. Cosmochim. Ac. $71: 2285-2298$. 
Solomon, D., J. Lehmann, J. Kinyangi, B. Liang, and T. Schafer. 2005. Carbon K-edge NEXAFS and FTIR-ATR spectroscopic investigation of organic carbon speciation in soils. Soil Sci. Soc. Am. J. 69:107-119.

Solomon, D., J. Lehmann, and W. Zech. 2000. Land use effects on soil organic matter properties of chromic Luvisols in the semiarid tropics: Carbon, nitrogen, lignin and carbohydrates. Agr. Ecosyst. Environ. 78:203-213.

Stevenson, S.J. 1994. Humic Chemistry: Genesis, Composition, Reactions. $2^{\text {nd }}$ ed. John Wiley and Sons, New York.

Stone, A.G., S.J. Traina, and H.A.J. Hoitnik. 2001. Particulate organic matter composition and Phthium Damping-Off of Cucumber. Soil Sci. Soc. Am. J. 65:761-770.

Sumner, M.E., and W. P. Miller. 1996. Cation exchange capacity, and exchange coefficients. In: D. L. Sparks (ed.) Methods of Soil Analysis. Part 2: Chemical properties. (3rd ed.) ASA, SSSA, CSSA, Madison, WI.

Swietlik, J. and E. Sikorska. 2004. Application of florescent spectroscopy in the studies of natural organic matter fractions reactivity with chlorine dioxide and ozone. Water Res. 38:3791-3799.

Traina, S.J., J. Novak, and N.E. Smeck. 1990. An ultraviolet absorbance method of estimating the percent aromatic carbon content of humic acids. J. Environ. Qual. 19:151-153.

Wang, K. and B. Xing. 2005. Structural and sorption characteristics of adsorbed humic acid on clay minerals. J. Environ. Qual. 34:342-349.

Zsolnay, A., E. Baiger, B. Jimenez, B. Steinweg, and F. Saccomandi. 1999. Differntiating with fluorescence spectroscopy the sources of dissolved organic matter in soils subjected to drying. Chemosphere. 38:45-50. 

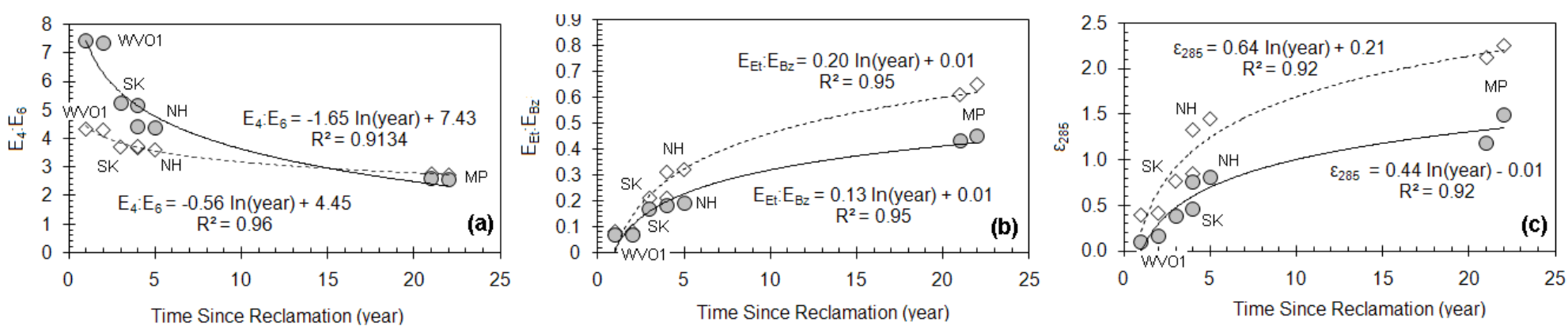

\section{Legend \\ $\diamond$ Resistant Fraction}

Labile Fraction
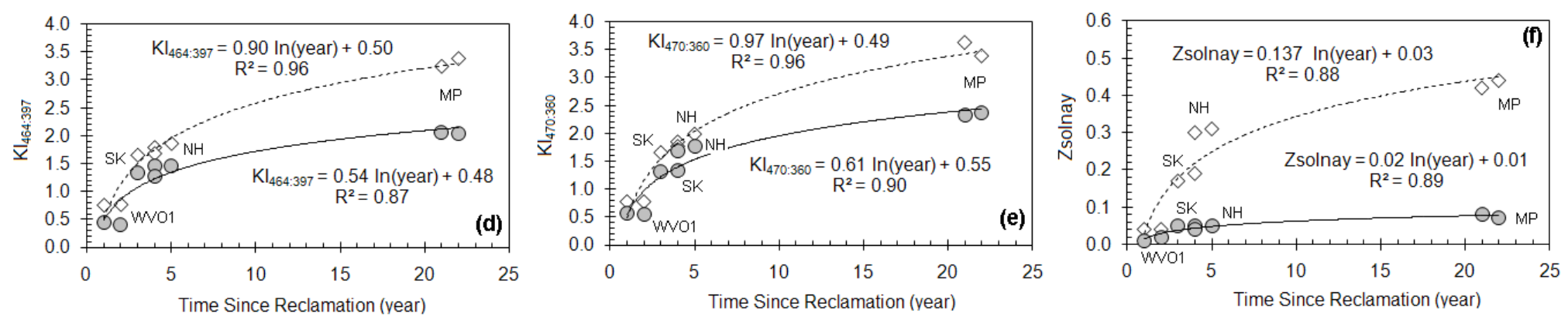

Figure 5-1: Relationship between UV-Visible and fluorescence spectroscopic indices with time since reclamation across the chronosequence for the labile and resistant SOC fractions at each minesite. 

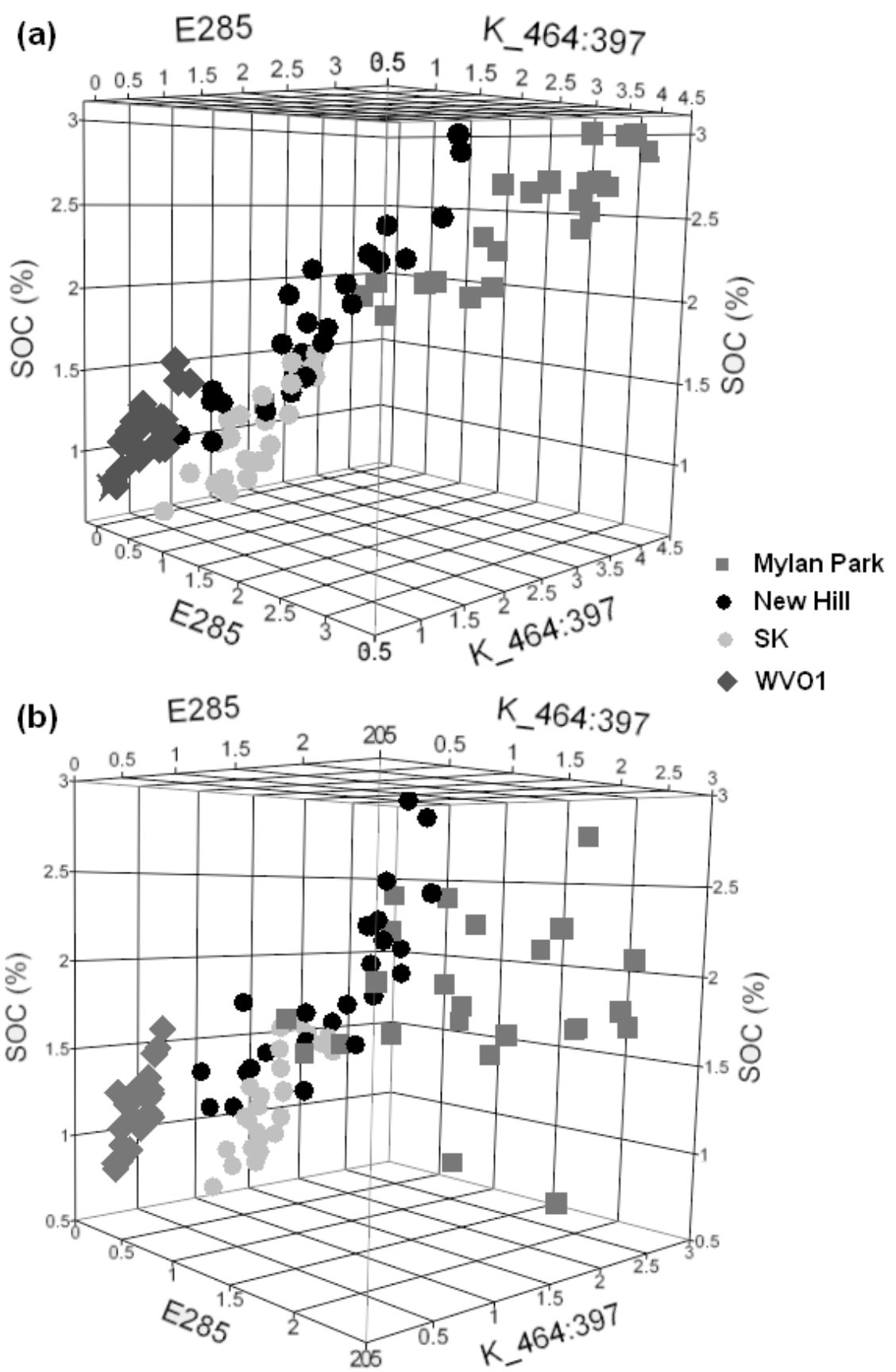

Figure 5-2: Ternary diagram illustrating locations of the reclaimed minesoils with respect to total SOC (\%) and the indices for the (a) resistant and (b) labile SOC fraction for 2008 sampling event. 


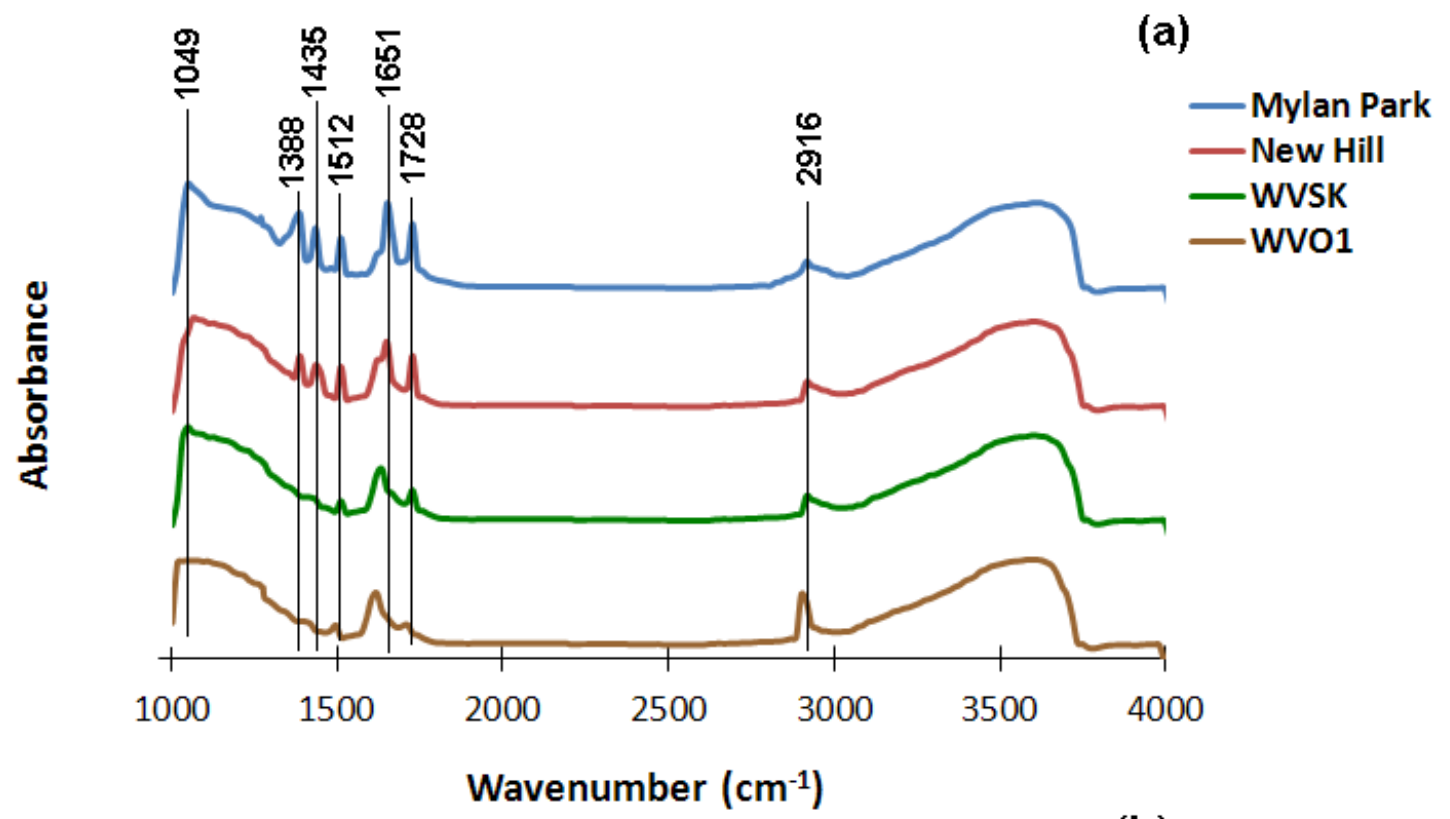

(b)

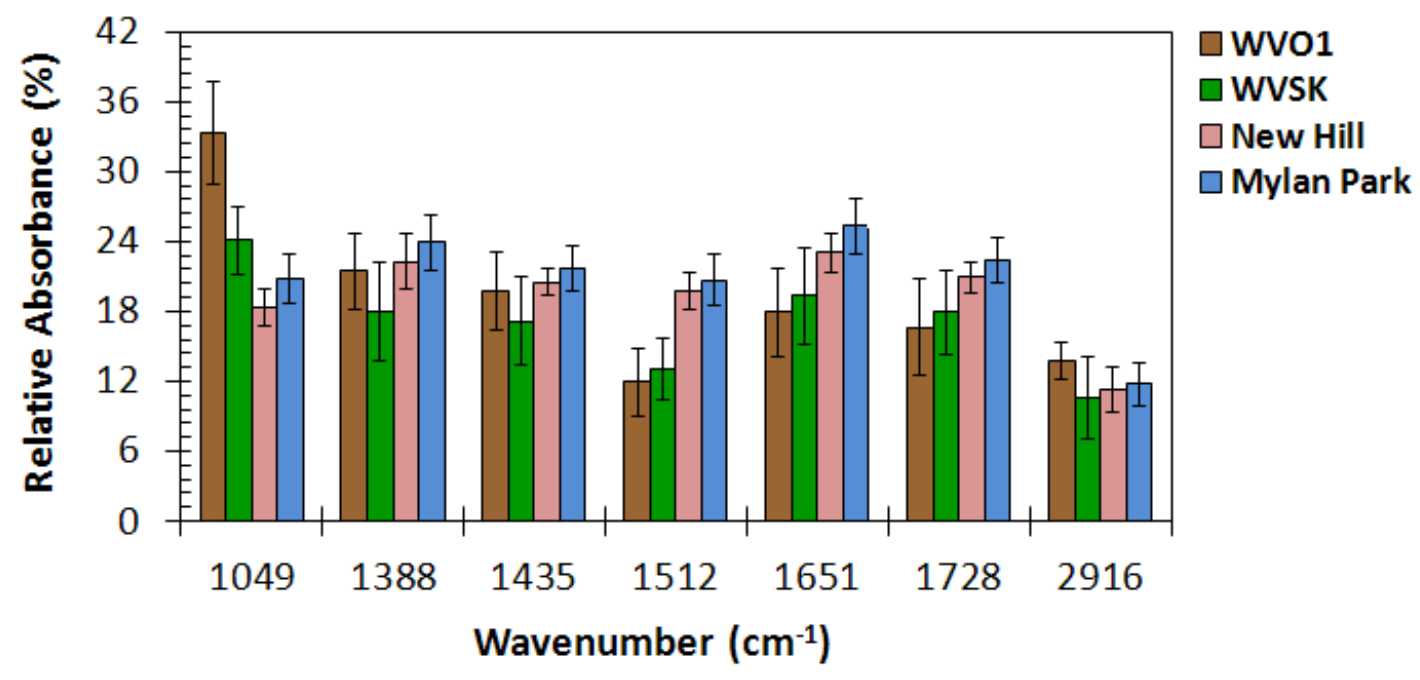

Figure 5-3: (a) FTIR-ATR spectra and (b) comparison of relative absorbances for specific absorption bands for each reclaimed minesoil. 
Table 5-1: General characteristics of the reclaimed minesites included in the study. and sampling processes

\begin{tabular}{|c|c|c|c|c|}
\hline Site Name & Mylan Park & New Hill & WVSK & WVO1 \\
\hline $\begin{array}{l}\text { Time Since Reclamation } \\
\text { (years) in } 2008\end{array}$ & 22 & 5 & 4 & 2 \\
\hline Method of Mining & \multirow{3}{*}{\multicolumn{4}{|c|}{$\begin{array}{l}- \\
-\end{array}$}} \\
\hline Type of Overburden & & & & \\
\hline Reclamation Method & & & & \\
\hline $\operatorname{SOC}\left(\mathrm{g} \mathrm{kg}^{-1}\right)$ & $21.73^{\mathrm{a}}(5.97)$ & $16.57^{\mathrm{b}}(6.19)$ & $11.96^{\mathrm{c}}(3.84)$ & $10.86^{\mathrm{c}}(1.66)$ \\
\hline $\mathrm{CEC}\left(\mathrm{cmol}_{\mathrm{c}} \mathrm{kg}^{-1}\right)$ & $11.78^{\mathrm{a}}(2.35)$ & $7.63^{\mathrm{b}}(1.38)$ & $4.75^{\mathrm{c}}(0.07)$ & $2.82^{\mathrm{d}}(0.06)$ \\
\hline $\mathrm{pH}$ & $7.43^{\mathrm{a}}$ & $6.67^{\mathrm{b}}$ & $5.45^{\mathrm{c}}$ & $6.68^{\mathrm{b}}$ \\
\hline $\mathrm{EC}\left(\mathrm{dS} \mathrm{m^{-1 }}\right)$ & $0.028^{\mathrm{c}}$ & $0.044^{\mathrm{b}}$ & $0.039^{\mathrm{b}}$ & $0.053^{\mathrm{a}}$ \\
\hline $\begin{array}{l}\text { Number of samples } \\
\text { collected }\end{array}$ & 74 & 79 & 83 & 64 \\
\hline
\end{tabular}

Time since reclamation, SOC, CEC and clay are given for the 2008 sampling event. For each soil parameter, same letters indicate not significant at $\alpha=0.05$; values in the parenthesis indicate standard deviation. 
Table 5-2: Description of UV-Vis and synchronous fluorescence spectroscopic indices used in the study (A: Absorption; F: Fluorescence maxima; DOC: Dissolved Organic Carbon).

\begin{tabular}{llll}
\hline Index Name & Index Type & $\begin{array}{l}\text { Absorption/Fluorescence } \\
\text { Ratios }\end{array}$ & References \\
\hline$\varepsilon_{285}$ & UV-Visible & $\mathrm{A}_{285 \mathrm{~nm}} / \mathrm{DOC}\left(\mathrm{mg} \mathrm{L}^{-1}\right)$ & Traina et al., (1990) \\
$\mathrm{E}_{4}: \mathrm{E}_{6}$ & UV-Visible & $\mathrm{A}_{465 \mathrm{~nm}} / \mathrm{A}_{665 \mathrm{~nm}}$ & Chin et al., (1994) \\
$\mathrm{E}_{\mathrm{ET}}: \mathrm{E}_{\mathrm{Bz}}$ & UV-Visible & $\mathrm{A}_{253 \mathrm{~nm}} / \mathrm{A}_{220 \mathrm{~nm}}$ & Khorsin et al., (1997) \\
$\mathrm{KI}_{464: 360} \& \mathrm{KI}_{470: 397}$ & $\begin{array}{l}\text { Synchronous } \\
\text { fluorescence }\end{array}$ & $\mathrm{F}_{464 \mathrm{~nm}} / \mathrm{F}_{360 \mathrm{~nm}} \& \mathrm{~F}_{470 \mathrm{~nm}} / \mathrm{F}_{397 \mathrm{~nm}}$ & $\begin{array}{l}\text { Kalbitz and Geyer } \\
\text { (2001) }\end{array}$ \\
& $\begin{array}{l}\text { Emission } \\
\text { Zsolnay }\end{array}$ & $\mathrm{F}_{570-641 \mathrm{~nm}} / \mathrm{F}_{356-432 \mathrm{~nm}}$ & Zsolnay et al., (1999) \\
\hline
\end{tabular}


Table 5-3a: Summary statistics of UV-Visible indices for the resistant SOC fraction for 2007 and 2008 sampling events

\begin{tabular}{|c|c|c|c|c|c|c|c|c|c|c|c|c|}
\hline \multirow{3}{*}{ Descriptive Parameter } & \multicolumn{12}{|c|}{ 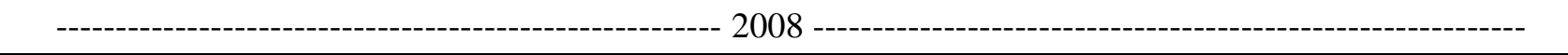 } \\
\hline & \multicolumn{4}{|c|}{-------------- $\mathrm{E}_{4}: \mathrm{E}_{6}$--------------- } & \multicolumn{4}{|c|}{---------- $\mathrm{E}_{\mathrm{ET}}: \mathrm{E}_{\mathrm{Bz}}$} & \multicolumn{4}{|c|}{----------------- $\varepsilon_{285}$} \\
\hline & WVO1 & WVSK & $\mathrm{NH}$ & MP & WVO1 & WVSK & $\mathrm{NH}$ & MP & WVO1 & WVSK & $\mathrm{NH}$ & MP \\
\hline Mean & $4.30^{\mathrm{a}}$ & $3.72^{\mathrm{b}}$ & $3.60^{\mathrm{b}}$ & $2.7^{\mathrm{c}}$ & $0.08^{\mathrm{c}}$ & $0.21^{\mathrm{b}}$ & $0.32^{\mathrm{b}}$ & $0.65^{\mathrm{a}}$ & 0.42 & 0.85 & 1.45 & $2.25^{\mathrm{a}}$ \\
\hline Median & 4.28 & 3.80 & 3.49 & 2.72 & 0.08 & 0.22 & 0.33 & 0.66 & 0.48 & 0.80 & 1.34 & 2.49 \\
\hline Standard Deviation & 0.69 & 0.40 & 0.41 & 0.35 & 0.02 & 0.04 & 0.06 & 0.05 & 0.23 & 0.33 & 0.61 & 0.80 \\
\hline $\mathrm{CV}(\%)$ & 16.06 & 10.82 & 11.44 & 12.81 & 23.57 & 18.66 & 17.05 & 7.07 & 53.49 & 38.79 & 42.52 & 35.61 \\
\hline Maximum & 6.19 & 4.39 & 4.64 & 3.33 & 0.10 & 0.27 & 0.43 & 0.72 & 0.74 & 1.34 & 2.57 & 3.21 \\
\hline Minimum & 3.18 & 3.06 & 3.04 & 2.16 & 0.04 & 0.12 & 0.20 & 0.56 & 0.01 & 0.22 & 0.29 & 0.32 \\
\hline Skewness & 0.55 & 0.17 & 0.58 & -0.08 & -0.75 & -0.73 & -0.43 & -0.38 & -0.43 & -0.03 & 0.16 & -0.76 \\
\hline Kurtosis & 1.07 & -1.27 & -0.14 & -1.01 & -0.24 & 0.68 & 0.11 & -0.69 & -1.12 & -0.95 & -0.61 & -0.10 \\
\hline \multirow{3}{*}{ Descriptive Parameter } & \multicolumn{12}{|c|}{------------------------------------------------------- 2007 ---------------------------------------------------------- } \\
\hline & \multicolumn{4}{|c|}{-------------- $\mathrm{E}_{4}: \mathrm{E}_{6}$-------------- } & \multicolumn{4}{|c|}{ 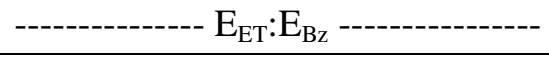 } & \multicolumn{4}{|c|}{------------------ $\varepsilon_{285}$---------------- } \\
\hline & WVO1 & WVSK & $\mathrm{NH}$ & MP & WVO1 & WVSK & NH & MP & WVO1 & WVSK & $\mathrm{NH}$ & MP \\
\hline Mean & $4.33^{\mathrm{a}}$ & $3.70^{\mathrm{b}}$ & $3.67^{\mathrm{b}}$ & $2.75^{\mathrm{c}}$ & $0.08^{\mathrm{c}}$ & $0.21^{\mathrm{b}}$ & $0.31^{b}$ & $0.61^{\mathrm{a}}$ & $0.40^{c}$ & $0.77^{\mathrm{b}}$ & $1.33^{\mathrm{b}}$ & $2.12^{\mathrm{a}}$ \\
\hline Median & 4.21 & 3.82 & 3.64 & 2.74 & 0.08 & 0.21 & 0.31 & 0.62 & 0.38 & 0.77 & 1.41 & 2.23 \\
\hline Standard Deviation & 0.70 & 0.34 & 0.35 & 0.40 & 0.01 & 0.02 & 0.02 & 0.04 & 0.15 & 0.35 & 0.54 & 0.74 \\
\hline $\mathrm{CV}(\%)$ & 16.22 & 9.23 & 9.44 & 14.70 & 8.74 & 9.61 & 7.44 & 7.21 & 37.10 & 45.03 & 40.35 & 34.67 \\
\hline Minimum & 6.47 & 4.29 & 4.33 & 3.44 & 0.09 & 0.24 & 0.35 & 0.69 & 0.68 & 1.39 & 2.06 & 3.39 \\
\hline Maximum & 3.01 & 3.10 & 3.10 & 2.08 & 0.06 & 0.16 & 0.26 & 0.52 & 0.19 & 0.18 & 0.01 & 0.51 \\
\hline Skewness & 3.45 & 1.20 & 1.24 & 1.36 & 0.03 & 0.07 & 0.08 & 0.18 & 0.49 & 1.21 & 2.05 & 2.88 \\
\hline Kurtosis & 0.91 & -0.36 & 0.10 & -0.06 & -0.29 & -0.60 & -0.23 & -0.38 & 0.48 & 0.02 & -1.08 & -0.25 \\
\hline
\end{tabular}


Table 5-3b: Summary statistics of UV-Visible indices for the labile SOC fraction for 2007 and 2008 sampling events

\begin{tabular}{|c|c|c|c|c|c|c|c|c|c|c|c|c|}
\hline \multirow{3}{*}{ Descriptive Parameter } & \multicolumn{12}{|c|}{ 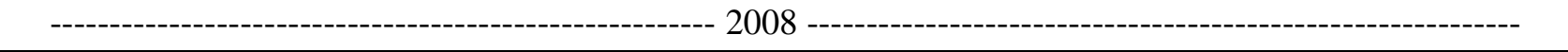 } \\
\hline & \multicolumn{4}{|c|}{---------------- $\mathrm{E}_{4}: \mathrm{E}_{6}$--------------- } & \multicolumn{4}{|c|}{------------- $\mathrm{E}_{\mathrm{ET}}: \mathrm{E}_{\mathrm{Bz}}$--------------- } & \multicolumn{4}{|c|}{------------------ $\varepsilon_{285^{---------------~}}$} \\
\hline & WVO1 & WVSK & $\mathrm{NH}$ & MP & WVO1 & WVSK & $\mathrm{NH}$ & MP & WVO1 & WVSK & $\mathrm{NH}$ & MP \\
\hline Mean & $7.36^{\mathrm{a}}$ & $5.14^{\mathrm{b}}$ & $4.39^{\mathrm{c}}$ & $2.56^{\mathrm{d}}$ & $0.07^{\mathrm{c}}$ & $0.18^{\mathrm{b}}$ & $0.19^{\mathrm{b}}$ & $0.45^{\mathrm{a}}$ & $0.16^{\mathrm{d}}$ & $0.46^{\mathrm{c}}$ & $0.81^{\mathrm{b}}$ & $1.49^{\mathrm{a}}$ \\
\hline Median & 7.30 & 5.21 & 4.35 & 2.59 & 0.07 & 0.18 & 0.19 & 0.44 & 0.14 & 0.43 & 0.92 & 1.36 \\
\hline Standard Deviation & 0.69 & 0.69 & 0.31 & 0.24 & 0.01 & 0.02 & 0.03 & 0.04 & 0.06 & 0.15 & 0.37 & 0.55 \\
\hline CV (\%) & 9.41 & 13.46 & 7.06 & 9.55 & 10.81 & 12.55 & 14.44 & 7.85 & 38.24 & 32.62 & 45.07 & 37.30 \\
\hline Maxis & 8.26 & 6.00 & 5.06 & 3.07 & 0.09 & 0.23 & 0.22 & 0.52 & 0.33 & 0.76 & 1.44 & 2.36 \\
\hline Minimum & 6.02 & 3.00 & 3.85 & 2.14 & 0.06 & 0.13 & 0.12 & 0.39 & 0.08 & 0.17 & 0.10 & 0.60 \\
\hline Skewn & -0.50 & -1.17 & 0.51 & -0.17 & 0.46 & -0.12 & -1.16 & 0.67 & 1.20 & 0.09 & -0.54 & 0.21 \\
\hline Kurtosis & -0.69 & 2.26 & -0.42 & -0.08 & -0.28 & 0.59 & 0.98 & -0.42 & 1.50 & -0.37 & -0.67 & -1.06 \\
\hline \multirow{3}{*}{ Descriptive Parameter } & \multicolumn{12}{|c|}{-------------------------------------------------- 2007 - } \\
\hline & \multicolumn{4}{|c|}{---------------- $\mathrm{E}_{4}: \mathrm{E}_{6}$--------------- } & \multicolumn{4}{|c|}{-------------- $\mathrm{E}_{\mathrm{ET}}: \mathrm{E}_{\mathrm{Bz}}$--------------- } & \multicolumn{4}{|c|}{------------------ $\varepsilon_{285}$---------------- } \\
\hline & WVO1 & WVSK & $\mathrm{NH}$ & MP & WVO1 & WVSK & $\mathrm{NH}$ & MP & WVO1 & WVSK & $\mathrm{NH}$ & MP \\
\hline Mean & $7.43^{\mathrm{a}}$ & $5.24^{\mathrm{b}}$ & $4.41^{\mathrm{c}}$ & $2.60^{\mathrm{d}}$ & $0.07^{\mathrm{d}}$ & $0.17^{\mathrm{c}}$ & $0.18^{\mathrm{b}}$ & $0.43^{\mathrm{a}}$ & $0.10^{\mathrm{d}}$ & $0.38^{\mathrm{c}}$ & $0.76^{\mathrm{b}}$ & $1.18^{\mathrm{a}}$ \\
\hline Median & 7.47 & 5.20 & 4.44 & 2.66 & 0.07 & 0.17 & 0.19 & 0.42 & 0.08 & 0.39 & 0.74 & 1.14 \\
\hline Standard Deviation & 0.63 & 0.62 & 0.29 & 0.26 & 0.01 & 0.02 & 0.02 & 0.04 & 0.08 & 0.07 & 0.22 & 0.41 \\
\hline CV $(\%)$ & 8.47 & 11.74 & 6.64 & 10.06 & 11.84 & 10.73 & 13.22 & 9.67 & 79.00 & 17.41 & 28.75 & 34.50 \\
\hline Maximum & 8.81 & 6.88 & 4.90 & 3.07 & 0.08 & 0.21 & 0.23 & 0.50 & 0.36 & 0.50 & 1.25 & 1.89 \\
\hline Minimum & 6.31 & 4.02 & 3.46 & 2.12 & 0.05 & 0.13 & 0.14 & 0.35 & 0.02 & 0.24 & 0.39 & 0.38 \\
\hline Skewness & -0.09 & 0.19 & -1.52 & -0.33 & 0.07 & -0.11 & 0.11 & -0.14 & 1.91 & -0.37 & 0.41 & -0.05 \\
\hline Kurtosis & -0.04 & 1.38 & 4.38 & -0.53 & -0.18 & 0.33 & -0.80 & -0.78 & 4.23 & -0.10 & -0.15 & -0.57 \\
\hline
\end{tabular}

Different letter for each individual UV-Visible index indicates significant difference at $\alpha=0.05(\mathrm{MP}=\mathrm{Mylan}$ Park, $\mathrm{NH}=\mathrm{New}$ Hill) 
Table 5-4a: Summary statistics of synchronous fluorescence indices for the resistant SOC fraction for 2007 and 2008 sampling events

\begin{tabular}{|c|c|c|c|c|c|c|c|c|c|c|c|c|}
\hline \multirow{3}{*}{ Descriptive Parameter } & \multicolumn{12}{|c|}{ 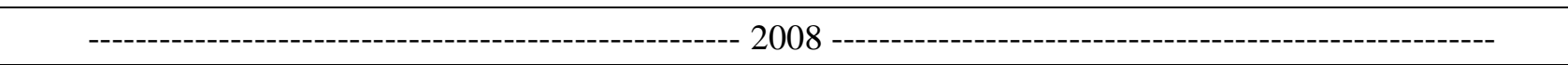 } \\
\hline & \multicolumn{4}{|c|}{------------ $\mathrm{KI}_{464: 397}$------------- } & \multicolumn{4}{|c|}{ 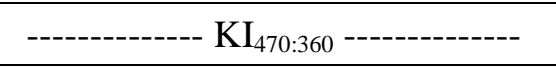 } & \multicolumn{4}{|c|}{-------------- Zsolnay ------------- } \\
\hline & WVO1 & WVSK & NH & MP & WVO1 & WVSK & NH & MP & WVO1 & WVSK & $\mathrm{NH}$ & MP \\
\hline Mean & $0.76^{\mathrm{d}}$ & $1.68^{\mathrm{c}}$ & $1.86^{\mathrm{b}}$ & $3.39^{\mathrm{a}}$ & $0.77^{\mathrm{d}}$ & $1.76^{\mathrm{c}}$ & $1.98^{\mathrm{b}}$ & $3.8^{\mathrm{a}}$ & $0.04^{\mathrm{d}}$ & $0.19^{c}$ & $0.31^{\mathrm{b}}$ & $0.44^{\mathrm{a}}$ \\
\hline Median & 0.78 & 1.64 & 1.85 & 3.43 & 0.72 & 1.77 & 2.02 & 3.90 & 0.04 & 0.19 & 0.30 & 0.44 \\
\hline Standard Deviation & 0.12 & 0.22 & & 0.65 & & 0.22 & 0.40 & 0.52 & 0.00 & 0.02 & 0.03 & 0.07 \\
\hline $\mathrm{CV}($ & 15.33 & 13.37 & 21.25 & 19.06 & 20.47 & 12.35 & 19.95 & 13.70 & 10.89 & 8.54 & & 15.00 \\
\hline Max & 1.00 & 1.99 & 2.66 & 4.46 & & & 2.63 & 4.45 & 0.05 & 0.22 & & 0.58 \\
\hline & 51 & & & 2.26 & & & & 2.74 & & & & 0.31 \\
\hline & -0.24 & -0 . & & -0.1 & & & & -0. & & & & 0.2 \\
\hline & -0.49 & 0.27 & -0.46 & -1.12 & -1.39 & -0.46 & -0.53 & -0.56 & 0.04 & -0.94 & 1.26 & 0.02 \\
\hline \multirow{3}{*}{ Descriptive Parameter } & \multicolumn{12}{|c|}{ 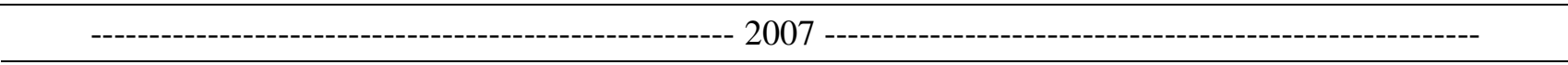 } \\
\hline & \multicolumn{4}{|c|}{ 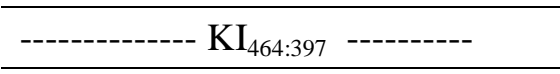 } & \multicolumn{4}{|c|}{-------------- $\mathrm{KI}_{470: 360}$-------------- } & \multicolumn{4}{|c|}{-------------- Zsolnay ------------- } \\
\hline & WVO1 & WVSK & $\mathrm{NH}$ & MP & WVO1 & WVSK & $\mathrm{NH}$ & MP & WVO1 & WVSK & $\mathrm{NH}$ & MP \\
\hline Mean & $0.75^{\mathrm{d}}$ & $1.65^{\mathrm{c}}$ & $1.79^{\mathrm{b}}$ & $3.25^{\mathrm{a}}$ & $0.77^{\mathrm{d}}$ & $1.65^{\mathrm{c}}$ & $1.84^{\mathrm{b}}$ & $3.62^{\mathrm{a}}$ & $0.04^{\mathrm{d}}$ & $0.17^{\mathrm{c}}$ & $0.30^{\mathrm{b}}$ & $0.42^{\mathrm{a}}$ \\
\hline Median & 0.72 & 1.61 & 1.83 & 3.27 & 0.76 & 1.67 & 1.86 & 3.66 & 0.04 & 0.17 & 0.30 & 0.43 \\
\hline Standard Deviation & 0.10 & 0.21 & 0.29 & 0.51 & 0.08 & 0.15 & 0.22 & 0.47 & 0.00 & 0.01 & 0.02 & 0.05 \\
\hline CV $(\%)$ & 13.44 & 12.71 & 16.01 & 15.66 & 9.88 & 8.93 & 12.08 & 13.09 & 5.86 & 8.61 & 6.56 & 12.37 \\
\hline Maxin & 0.96 & 2.18 & 2.26 & 4.14 & 0.96 & 1.95 & 2.21 & 4.26 & 0.04 & 0.19 & 0.34 & 0.49 \\
\hline Minin & 0.59 & 1.41 & 1.03 & 2.28 & 0.64 & 1.37 & 1.36 & 2.50 & 0.03 & 0.14 & 0.26 & 0.32 \\
\hline Skew & 0.41 & 1.07 & -0.91 & 0.02 & 0.47 & -0.06 & -0.28 & -0.77 & -0.01 & 0.02 & 0.25 & -0.71 \\
\hline Kurtosis & -0.59 & 0.97 & 1.15 & -0.85 & 0.09 & -0.42 & -0.25 & 0.18 & -1.43 & -1.18 & -0.56 & -0.37 \\
\hline
\end{tabular}


Table 5-4b: Summary statistics of synchronous fluorescence indices for the labile SOC fraction for 2007 and 2008 sampling events

\begin{tabular}{|c|c|c|c|c|c|c|c|c|c|c|c|c|}
\hline \multirow{3}{*}{ Descriptive Parameter } & \multicolumn{12}{|c|}{-----1 } \\
\hline & \multicolumn{4}{|c|}{ 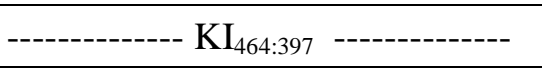 } & \multicolumn{4}{|c|}{ 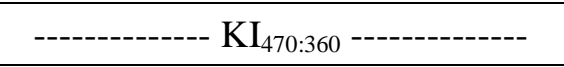 } & \multicolumn{4}{|c|}{-------------- Zsolnay ------------- } \\
\hline & WVO1 & WVSK & $\mathrm{NH}$ & MP & WVO1 & WVSK & $\mathrm{NH}$ & MP & WVO1 & WVSK & $\mathrm{NH}$ & MP \\
\hline Mean & $0.41^{\mathrm{d}}$ & $1.27^{\mathrm{c}}$ & $1.46^{\mathrm{b}}$ & $2.03^{\mathrm{a}}$ & $0.55^{\mathrm{d}}$ & $1.33^{\mathrm{c}}$ & $1.77^{\mathrm{b}}$ & $2.36^{\mathrm{a}}$ & $0.02^{c}$ & $0.04^{\mathrm{b}}$ & $0.05^{\mathrm{b}}$ & $0.07^{\mathrm{a}}$ \\
\hline Median & 0.43 & 1.24 & 1.47 & 2.07 & 0.55 & 1.34 & 1.77 & 2.36 & 0.02 & 0.04 & 0.05 & 0.07 \\
\hline Standard Deviation & 01 & 0.02 & & 0.21 & 0.02 & & 0.03 & 0.19 & 0.00 & 0.00 & 0.01 & 0.01 \\
\hline $\mathrm{CV}(c$ & 24.90 & 12.36 & 21.76 & 22.45 & 22.85 & & 10.05 & 18.59 & 11.11 & 8.50 & 13.33 & 19.61 \\
\hline Max & 0.57 & 1.56 & 1.96 & 2.77 & 0.73 & & 2.13 & 3.14 & 0.02 & 0.05 & 0.06 & 0.10 \\
\hline & & & & 1.26 & & & & 1.60 & & 0.04 & & 0.04 \\
\hline & & & & -0. & & & -0. & 0.0 & 0.3 & -0 & 46 & -0.95 \\
\hline & -1.24 & -0.44 & -1.06 & -0.89 & -1.21 & 0.60 & -0.58 & -0.86 & -0.90 & -0.98 & -0.51 & 0.33 \\
\hline \multirow{3}{*}{ Descriptive Parameter } & \multicolumn{12}{|c|}{ - } \\
\hline & \multicolumn{4}{|c|}{------------- $\mathrm{KI}_{464: 397}$-------------- } & \multicolumn{4}{|c|}{-------------- $\mathrm{KI}_{470: 360 \text {-------------- }}$} & \multicolumn{4}{|c|}{-------------- Zsolnay -------------- } \\
\hline & WVO1 & WVSK & $\mathrm{NH}$ & MP & WVO1 & WVSK & $\mathrm{NH}$ & MP & WVO1 & WVSK & $\mathrm{NH}$ & MP \\
\hline Mean & $0.45^{\mathrm{d}}$ & $1.33^{\mathrm{c}}$ & $1.46^{\mathrm{b}}$ & $2.05^{\mathrm{a}}$ & $0.57^{\mathrm{d}}$ & $1.32^{\mathrm{c}}$ & $1.69^{\mathrm{b}}$ & $2.32^{\mathrm{a}}$ & $0.01^{\mathrm{c}}$ & $0.05^{\mathrm{b}}$ & $0.05^{\mathrm{b}}$ & $0.08^{\mathrm{a}}$ \\
\hline Median & 0.46 & 1.30 & 1.47 & 2.05 & 0.55 & 1.30 & 1.68 & 2.39 & 0.01 & 0.05 & 0.05 & 0.08 \\
\hline Standard Deviation & 0.01 & 0.02 & 0.08 & 0.14 & 0.02 & 0.02 & 0.02 & 0.13 & 0.00 & 0.00 & 0.01 & 0.01 \\
\hline $\mathrm{CV}(\%)$ & 21.85 & 10.29 & 19.59 & 18.18 & 23.26 & 10.16 & 8.14 & 15.41 & 17.60 & 8.36 & 11.34 & 12.27 \\
\hline Maximum & 0.63 & 1.58 & 1.94 & 2.84 & 0.81 & 1.59 & 1.93 & 3.03 & 0.02 & 0.05 & 0.06 & 0.09 \\
\hline Minim & 0.27 & 1.11 & 0.96 & 1.43 & 0.35 & 1.06 & 1.40 & 1.71 & 0.01 & 0.04 & 0.04 & 0.05 \\
\hline Skew & -0.12 & 0.31 & 0.11 & 0.22 & 0.15 & 0.2 & -0.11 & 0.04 & 0.88 & -0.37 & 0.13 & -0.67 \\
\hline Kurtosis & -0.55 & -0.73 & -0.65 & -0.32 & -0.96 & -0.53 & -0.25 & -0.66 & 0.62 & -0.58 & -0.68 & 0.04 \\
\hline
\end{tabular}

Different letter for each individual fluorescence index indicates significant difference at $\alpha=0.05(\mathrm{MP}=$ Mylan Park, NH $=\mathrm{New}$ Hill) 
Table 5-5: Regression coefficients for different spectroscopic indices in the minesoils for both years for the resistant SOC fractions $(p<0.05)$.

\begin{tabular}{|c|c|c|c|c|c|c|}
\hline $\begin{array}{l}\text { Minesoil } \\
\text { Name }\end{array}$ & $\begin{array}{l}\text { Spectroscopic } \\
\text { Indices }\end{array}$ & $\begin{array}{l}\text { Sampling } \\
\text { Year }\end{array}$ & $\operatorname{SOC}\left(\mathrm{g} \mathrm{kg}^{-1}\right)$ & $\begin{array}{c}\varepsilon_{285} \\
(\mathrm{mg} / \mathrm{L})\end{array}$ & $\mathrm{KI}_{470: 360}$ & $\mathrm{KI}_{470: 360}$ \\
\hline \multirow{8}{*}{ Mylan Park } & \multirow{2}{*}{$\varepsilon_{285}(\mathrm{mg} / \mathrm{L})$} & 2008 & 0.86 & & & \\
\hline & & 2007 & 0.77 & & & \\
\hline & \multirow{2}{*}{$\mathrm{KI}_{470: 360}$} & 2008 & 0.78 & 0.73 & & \\
\hline & & 2007 & 0.73 & 0.65 & & \\
\hline & \multirow{2}{*}{$\mathrm{KI}_{470: 360}$} & 2008 & 0.67 & 0.68 & 0.91 & \\
\hline & & 2007 & 0.73 & 0.70 & 0.72 & \\
\hline & \multirow{2}{*}{ Zsolnay } & 2008 & 0.71 & 0.64 & 0.46 & 0.34 \\
\hline & & 2007 & 0.64 & 0.46 & 0.49 & 0.43 \\
\hline \multirow{8}{*}{ New Hill } & \multirow{2}{*}{$\varepsilon_{285}(\mathrm{mg} / \mathrm{L})$} & 2008 & 0.85 & & & \\
\hline & & 2007 & 0.70 & & & \\
\hline & \multirow{2}{*}{$\mathrm{KI}_{470: 360}$} & 2008 & 0.70 & 0.67 & & \\
\hline & & 2007 & 0.66 & 0.59 & & \\
\hline & \multirow{2}{*}{$\mathrm{KI}_{470: 360}$} & 2008 & 0.68 & 0.62 & 0.87 & \\
\hline & & 2007 & 0.66 & 0.81 & 0.70 & \\
\hline & \multirow{2}{*}{ Zsolnay } & 2008 & 0.71 & 0.56 & 0.56 & 0.60 \\
\hline & & 2007 & 0.64 & 0.53 & 0.44 & 0.42 \\
\hline \multirow{8}{*}{ WVSK } & \multirow{2}{*}{$\varepsilon_{285}(\mathrm{mg} / \mathrm{L})$} & 2008 & 0.70 & & & \\
\hline & & 2007 & 0.63 & & & \\
\hline & \multirow{2}{*}{$\mathrm{KI}_{470: 360}$} & 2008 & 0.60 & 0.67 & & \\
\hline & & 2007 & 0.63 & 0.52 & & \\
\hline & \multirow{2}{*}{$\mathrm{KI}_{470: 360}$} & 2008 & 0.57 & 0.59 & 0.69 & \\
\hline & & 2007 & 0.50 & 0.55 & 0.41 & \\
\hline & \multirow{2}{*}{ Zsolnay } & 2008 & 0.66 & 0.69 & 0.44 & 0.51 \\
\hline & & 2007 & 0.54 & 0.46 & 0.40 & 0.17 \\
\hline \multirow{8}{*}{ WVO1 } & \multirow{2}{*}{$\varepsilon_{285}(\mathrm{mg} / \mathrm{L})$} & 2008 & 0.61 & & & \\
\hline & & 2007 & 0.62 & & & \\
\hline & \multirow{2}{*}{$\mathrm{KI}_{470: 360}$} & 2008 & 0.56 & 0.55 & & \\
\hline & & 2007 & 0.33 & 0.50 & & \\
\hline & \multirow{2}{*}{$\mathrm{KI}_{470: 360}$} & 2008 & 0.56 & 0.49 & 0.66 & \\
\hline & & 2007 & 0.46 & 0.5 & 0.42 & \\
\hline & \multirow{2}{*}{ Zsolnay } & 2008 & 0.59 & 0.24 & 0.31 & 0.30 \\
\hline & & 2007 & 0.57 & 0.31 & 0.13 & 0.21 \\
\hline
\end{tabular}


Table 5-6: Regression coefficients for different spectroscopic indices in the minesoils for both years for the labile SOC fractions $(p<0.05)$.

\begin{tabular}{|c|c|c|c|c|c|c|}
\hline $\begin{array}{l}\text { Minesoil } \\
\text { Name }\end{array}$ & $\begin{array}{l}\text { Spectroscopic } \\
\text { Indices }\end{array}$ & $\begin{array}{l}\text { Sampling } \\
\text { Year }\end{array}$ & $\operatorname{SOC}\left(\mathrm{g} \mathrm{kg}^{-1}\right)$ & $\begin{array}{c}\varepsilon_{285} \\
(\mathrm{mg} / \mathrm{L})\end{array}$ & $\mathrm{KI}_{470: 360}$ & $\mathrm{KI}_{470: 360}$ \\
\hline \multirow{8}{*}{ Mylan Park } & \multirow{2}{*}{$\varepsilon_{285}(\mathrm{mg} / \mathrm{L})$} & 2008 & 0.64 & & & \\
\hline & & 2007 & 0.62 & & & \\
\hline & \multirow{2}{*}{$\mathrm{KI}_{470: 360}$} & 2008 & 0.62 & 0.35 & & \\
\hline & & 2007 & 0.64 & 0.53 & & \\
\hline & \multirow{2}{*}{$\mathrm{KI}_{470: 360}$} & 2008 & 0.68 & 0.44 & 0.89 & \\
\hline & & 2007 & 0.64 & 0.42 & 0.85 & \\
\hline & \multirow{2}{*}{ Zsolnay } & 2008 & 0.58 & 0.35 & 0.25 & 0.30 \\
\hline & & 2007 & 0.62 & 0.42 & 0.42 & 0.47 \\
\hline \multirow{8}{*}{ New Hill } & \multirow{2}{*}{$\varepsilon_{285}(\mathrm{mg} / \mathrm{L})$} & 2008 & 0.63 & & & \\
\hline & & 2007 & 0.61 & & & \\
\hline & \multirow{2}{*}{$\mathrm{KI}_{470: 360}$} & 2008 & 0.6 & 0.53 & & \\
\hline & & 2007 & 0.59 & 0.39 & & \\
\hline & \multirow{2}{*}{$\mathrm{KI}_{470: 360}$} & 2008 & 0.56 & 0.53 & 0.82 & \\
\hline & & 2007 & 0.53 & 0.33 & 0.84 & \\
\hline & \multirow{2}{*}{ Zsolnay } & 2008 & 0.58 & 0.27 & 0.27 & 0.21 \\
\hline & & 2007 & 0.56 & 0.27 & 0.14 & 0.12 \\
\hline \multirow{8}{*}{ WVSK } & \multirow{2}{*}{$\varepsilon_{285}(\mathrm{mg} / \mathrm{L})$} & 2008 & 0.54 & & & \\
\hline & & 2007 & 0.52 & & & \\
\hline & \multirow{2}{*}{$\mathrm{KI}_{470: 360}$} & 2008 & 0.56 & 0.43 & & \\
\hline & & 2007 & 0.56 & 0.17 & & \\
\hline & \multirow{2}{*}{$\mathrm{KI}_{470: 360}$} & 2008 & 0.56 & 0.29 & 0.65 & \\
\hline & & 2007 & 0.51 & 0.22 & 0.69 & \\
\hline & \multirow{2}{*}{ Zsolnay } & 2008 & 0.53 & 0.33 & 0.25 & 0.25 \\
\hline & & 2007 & 0.51 & 0.36 & 0.44 & 0.39 \\
\hline \multirow{8}{*}{ WVO1 } & \multirow{2}{*}{$\varepsilon_{285}(\mathrm{mg} / \mathrm{L})$} & 2008 & 0.46 & & & \\
\hline & & 2007 & 0.32 & & & \\
\hline & \multirow{2}{*}{$\mathrm{KI}_{470: 360}$} & 2008 & 0.49 & 0.29 & & \\
\hline & & 2007 & 0.47 & 0.29 & & \\
\hline & \multirow{2}{*}{$\mathrm{KI}_{470: 360}$} & 2008 & 0.49 & 0.28 & 0.84 & \\
\hline & & 2007 & 0.52 & 0.15 & 0.85 & \\
\hline & \multirow{2}{*}{ Zsolnay } & 2008 & 0.46 & 0.35 & 0.42 & 0.37 \\
\hline & & 2007 & 0.43 & 0.13 & 0.16 & 0.17 \\
\hline
\end{tabular}




\title{
CHAPTER 6:
}

Characterization of Different Soil Carbon Pools and Coal Carbon in a Reclaimed Minesoil Chronosequence

\begin{abstract}
Reclaimed minesoils can contribute significantly towards terrestrial carbon sequestration processes. However, a major difficulty is to distinguish coal carbon (coal-C) from soil organic carbon (SOC). We implemented a sequential chemi-thermal extraction procedure to characterize coal-C and several soil carbon (SC) fractions in a reclaimed minesoil chronosequence. Total soil carbon (TSC) was about $22 \mathrm{~g} \mathrm{~kg}^{-1}$ and $11 \mathrm{~g} \mathrm{~kg}^{-1}$ respectively in the oldest and the youngest minesoil while total soil organic carbon (TSOC) was about $20 \mathrm{~g} \mathrm{~kg}^{-1}$ and $8 \mathrm{~g} \mathrm{~kg}^{-1}$ in the oldest and the youngest minesoil respectively. The humin $\mathrm{C}$ fraction was about $43 \%$ and $7.5 \%$ of TSOC in the oldest and the youngest minesoils respectively while the acid-hydrolysable $\mathrm{C}$ fraction was about $41 \%$ and $24 \%$ of TSOC in the youngest and oldest minesoil respectively. Coal-C was similar in all minesoils ranging from about 0.60 to $1.50 \mathrm{~g} \mathrm{~kg}^{-1}$ and was less than $15 \%$ of the TSC. There were distinct relationships between the SC pools and TSC, influenced by time since reclamation. A stronger positive relationship was observed between the stable humin fraction and TSC in the older minesoils while the TSC of the younger minesoils were more influenced by the labile SC fractions.
\end{abstract}

Keywords: carbon sequestration, minesoils, coal-C, sequential extraction, SOC pools. 


\subsection{Introduction}

Surface mining for coal is the major landuse practice in the Appalachian regions that affects landscape patterns and ecosystem dynamics. However, it has been shown that with adoption of appropriate restoration strategies, and increasing time since reclamation, reclaimed minesoils can sequester significant amounts of carbon and mitigate greenhouse gas emissions (Akala and Lal, 2000, 2001; Shukla et al., 2005a, 2005b; Sherstha and Lal, 2006).

One problem in the determination of $\mathrm{C}$ sequestration in reclaimed minesoils is the intricate mixing of coal particles/dust with the spoil materials during overburden handling and reclamation activities (Rumple et al., 1988). Distinguishing between geogenic carbon (coal-C) and pedogenic carbon (SOC) is difficult and attempts to isolate and quantify coal-C in reclaimed minesoils have been scant. Stable isotope $\left(\delta^{13} \mathrm{C}\right)$ measurements (Ussiri and Lal, 2008) and radiocarbon $\left({ }^{14} \mathrm{C}\right.$ ) methods (Rumpel et al., 1988, 2003; Chabbi et al., 2006; Ussiri and Lal, 2008) have often been used to distinguish between "recent" or plant-derived and "old" or coal-derived carbon. Several thermogravimetric and differential thermogravimetric (TG/DTG) techniques have been used to identify coal, tar and other charred residual materials in soils (Siewert, 2004). These methods have also been used to distinguish between soil organic matter (SOM), coal, and limestone and other charred materials in soils and in minesoil chronosequences (Maharaj et al., 2007a, b). However, radiocarbon, stable isotope and thermogravimetric methods are relatively expensive techniques and require significant resources, expertise in sample preparation, data handling and interpretation of the results. Alternative sequential extraction methods have been proposed to isolate coal-C, based on isotopic characteristics of recent (SOC) and old (coal) carbon (Ussiri and Lal, 2008). Sequential extraction schemes have been successful in distinguishing SOC from charred C in soils and sediments (Gelinas et al., 2001)

In a previous study we observed that soil $\mathrm{C}$ increased with increasing time since reclamation along a minesoil chronosequence (Chapter 2). The objective of this research was to determine isolate SOC pools coal-C and determine their relationships with time since reclamation along the minesoil chronosequence. 


\subsection{Materials and Methods}

A chronosequence of four surface minesoils was identified in Monongalia County $\left(39^{\circ} 37^{\prime} 45^{\prime \prime} \mathrm{N}, 79^{\circ} 57^{\prime} 22^{\prime \prime} \mathrm{W}\right)$, West Virginia with time since reclamation ranging from 1 to 23 years (Table 6-1). The reclaimed minesites were owned and operated by the same mining company and had similar topographic, climatic, and geologic characteristics. All the sites were reclaimed to pasture species following guidelines set by Surface Mining Control and Reclamation (SMCRA, 1977). Soil core samples were collected from the upper 0-5 cm from each site during July-September of 2008 using site-specific irregular grids $(7 * 5 \mathrm{~m})$ based on the previous knowledge of spatial variability of SOC. Soil samples were air dried, ground, and sieved $(<2 \mathrm{~mm})$ and total soil carbon (TSC) was determined by dry combustion (LECO TruSpec CHN, LECO Corp. St. Joseph, MI). before the sequential extraction method. Prior to the analysis, inorganic carbonates were removed by $1 \mathrm{M} \mathrm{HCl}$ treatment, which were $<4 \%$ of total soil carbon (TSC) in each minesoil. For the extraction procedure, a set of 25 representative sub-samples were selected from each minesoil based on their aerial distribution in the field and range of TSC.

The soil carbon pools for each minesoil were isolated by a sequential chemithermal extraction procedure (Ussiri and Lal, 2008). Two grams of carbonate-free soil was used for the extraction which involved sequential application of strong base, acid and heat (Figure 6-1). After each extraction step, residual soils were washed twice with deionized water (DI). Residual SC (RSC) remaining after each extraction step was determined as described above. Hydrolysable SC (HSC) for any particular extraction step was determined by difference such that:

Base-hydrolysable SC (BHSC) = TSC - RSC after the base hydrolysis (BRSC)

Acid-hydrolysable SC (AHSC) = BRSC - RSC after the acid hydrolysis (ARSC)

HF-hydrolysable SC (HFHSC) = ARSC - HFRSC

Final base-hydrolysable SC (FBHSC) = HFRSC - FBRSC

Coal-C

$=$ FBRSC - RSC after heat (hRSC)

Total SOC (TSOC) was determined by adding all the HSC pools (BHSC + AHSC + HFSC + FBSC). The relative proportion of each HSC pool was expressed as percentages of TSOC. Total analyzed soil carbon (TASC) was determined by adding 
TSOC and coal-C. Total recovery was calculated by dividing TASC by TSC and expressed as percentages of TSC to evaluate the overall efficiency of the extraction scheme. An artificial coal:soil (w:w) mixture with 100\%, 50\% and 10\% coal was used to evaluate the effect of the extractants on coal-C.

Each soil carbon fraction were compared between the minesoils across the chronosequence by one-way ANOVA (SAS Institute, 2003) at the $p<0.05$ significance level. Regression analyses were conducted to determine the relationships between each HSC pools with TSC for each minesoil.

\subsection{Results and Discussion}

Total soil carbon (TSC) ranged between 23.31 and $11.38\left(\mathrm{~g} \mathrm{~kg}^{-1}\right)$, decreasing significantly along the chronosequence following the order $\mathrm{MP}>\mathrm{NH}>\mathrm{SK} \approx \mathrm{WVO} 1$ (Table 6-2). Average TSOC ranged from 19.84 to $7.84\left(\mathrm{~g} \mathrm{~kg}^{-1}\right)$ and decreased significantly following the order of TSC (Table 6-2). Significantly larger TSC $\left(\mathrm{g} \mathrm{kg}^{-1}\right)$ and TSOC $\left(\mathrm{g} \mathrm{kg}^{-1}\right)$ in older than younger minesoils indicated positive effects of increasing time since reclamation on soil carbon dynamics in this minesoil chronosequence. The average BHSC pool $\left(\mathrm{g} \mathrm{kg}^{-1}\right)$ ranged between 4.88 and $2.34 \mathrm{~g} \mathrm{~kg}^{-1}$ following the order MP $>$ NH $>$ WVO1 $\approx$ SK (Table 6-3). Base hydrolysis selectively removes ester-bound biopolymers enriching the residual soil organic matter (SOM) with alkyl carbon species such as alkanols, alkanoic acids, hydroxyalkanoic acids etc (KögelKnabner et al., 1992; Nierop et al., 2003; Rumpel et al., 2005). Soil carbon species remaining after base hydrolysis are either non-ester compounds and/or associated very strongly with the soil mineral matrix (Zegouagh et al., 2004; Rumpel et al., 2005). The AHSC pool $\left(\mathrm{g} \mathrm{kg}^{-1}\right)$ averaged between 4.94 and $2.19 \mathrm{~g} \mathrm{~kg}^{-1}$ following the order MP $\approx \mathrm{NH}$ $>$ WVO1 $\approx$ SK (Table 6-3). Acid-hydrolysis removes relatively labile SOM components such as proteins and polysaccharides (Barriuso et al., 1987, Ostle et al., 1999) enriching the residual, much older (Kiem et al., 2000) SOM with more recalcitrant species including long-chain alkyls, waxes, lignin, and other aromatics (Schnitzer \& Preston, 1983; Paul et al., 2000, 1997; Collins et al., 2000; Haile-Mariam et al., 2000; Paul et al. 2001a; 2001b; 2006; Tan et al. 2006). The absolute amounts of base- and acid- 
hydrolysable (BHSC and AHSC) carbon fractions were higher in the older than the younger minesoils.

The average HFHSC pool ranged from 1.77 to $1.23 \mathrm{~g} \mathrm{~kg}^{-1}$ with no significant differences between the minesoils (Table 6-3). Hydrofluoric acid (HF) selectively dissolves soil minerals (alluminosilicates) releasing mineral-bound carbon (Dick et al., 2006: Eusterhues et al., 2007: 2006, 2005, 2003: Dalmolin et al., 2006; Mikutta et al., 2007). Mineral-association reduces SOM degradation (Jones and Edwards, 1998; Kalbitz et al., 2005) by providing protection from microbial enzymes (Kaiser and Guggenberger, 2003, 2007; Zimmerman et al., 2004). More mineral-bound carbon in younger minesoils may indicate that formation of organo-mineral complexes are an important stabilizing mechanism for soil carbon in the younger minesoils. Higher clay contents in the younger minesoils might be a cause of higher organo-mineral species in younger minesoils. However, more information on mineral types (1:1 vs. 2:1 clays) and their distribution in individual minesoils is necessary to understand their role in soil $\mathrm{C}$ dynamics.

The FBSC pool ranged between 9.23 to and $0.60 \mathrm{~g} \mathrm{~kg}^{-1}$ on average, decreasing in the order MP > NH > SK > WVO1 (Table6- 3). Soil carbon pool, left after the final base hydrolysis is considered humin, the most stable and resistant soil carbon pool (Ussiri and Lal, 2008).

Relative proportions of each HSC pool in TSOC for each minesoil showed that average BHSC (\%) ranged from about 31 to $22 \%$ of TSOC and decreased following the order $\mathrm{SK} \approx \mathrm{WVO} 1>\mathrm{MP} \approx \mathrm{NH}$ (Figure 6-2). The AHSC (\%) were between 41 and 24\%, decreasing as $\mathrm{WVO} 1 \approx \mathrm{NH}>\mathrm{MP} \approx \mathrm{SK}$. Proteins and carbohydrates are results of soil biological processes such as microbial and plant exudates (Spielvogel et al., 2007). As minesoils age (longer time since reclamation) plant species begin to grow and microbial processes are restored in reclaimed minesoils (Mummey et al., 2002). This might be the cause of higher absolute concentration of these types of carbon species in older minesoils. However, higher relative proportions of these labile carbon components in the TSOC in the younger than older minesoils indicated that with increasing time since reclamation the labile carbon pools become less dominant proportionally, in minesoil organic carbon budget. 
The humin fraction constituted about 44 and 7\% of TSOC in this minesoil chronosequence and decreased following the order MP $>$ NH $>$ SK $>$ WVO1. Significantly higher humin in the older minesoils (> 40\% of TSOC) indicated that with increasing time since reclamation the stable carbon pool increased in these minesoil chronosequence and became more important than any other $\mathrm{C}$ pools in minesoil $\mathrm{C}$ budget. Humin constituted $<8 \%$ of TSOC in the youngest (WVO1) minesoil indicating that not enough time had been elapsed to accumulate this stable $\mathrm{C}$ pool.

Coal-C ranged from between 1.76 and $0.6 \mathrm{~g} \mathrm{~kg}^{-1}$ with no statistically significant difference between the minesoils (Table 6-4). Coal-C was between 2.5 and $14 \%$ of TSC with lowest in the older and highest in the younger minesoils. This indicated that the contribution of coal-C towards TSC in these minesoils and was not significant in the C budget of the older minesoils. Higher coal-C at SK could be due to the recent soilscraping activities that exposed the subsoil with more coal. No significant $(p<0.05)$ differences were found between TSC and TSOC for any minesoil except WVO1 indicating that total soil carbon can be considered as soil organic carbon in this minesoil chronosequence except for the youngest minesoil. This again reflects the most recent reclamation activities at WVO1, which offered inadequate time to develop soil horizons and therefore TSOC at WVO1. Lower recovery at WVO1 (84\%) at WVO1 could also account for inappropriate $\mathrm{C}$ mass balance and therefore differences in TSOC and TSC at this site.

The total recovery of soil carbon was between 84 and $94 \%$ for the minesoil and highest for MP and lowest for WVO1 (Table 6-5). Total recovery by this sequential extraction method was better for the older (> 90\%) than the younger minesoils $(83-90 \%)$ indicating that this method can be applied to minesoils more than 20 -yr old to characterize coal-C and other soil carbon pools.

Significant $(p<0.01)$ positive relationships were observed between TSC and humic for all minesoils with $\mathrm{R}^{2}$ values decreasing in the order $\mathrm{MP}>\mathrm{NH}>\mathrm{SK}>\mathrm{WVO} 1$ (Table 6-6). Highest $\mathrm{R}^{2}$ values between TSC and AHSC and that between TSC and mineral-bound C (HFHSC) were found for WVO1. Strong positive relationships between TSC and the humin fractions in the older than younger minesoils indicated that accumulation of humin influenced $\mathrm{C}$ dynamics more as the minesoils aged, i.e. with 
increasing time since reclamation. On the other hand, the strong positive relationship between AHSC with TSC indicated the influence of labile $\mathrm{C}$ components in $\mathrm{C}$ dynamics in younger minesoils. Overall, this suggested that different SC pools affect the overall $\mathrm{C}$ dynamics in different ways in this minesoil chronosequence and is 'guided' by time since reclamation. No significant relationships were observed between coal-C and any of the HSC pools or TSC for any minesoil. Coal-C was unrelated with TSC or any $\mathrm{C}$ pools indicating that overall TSOC was not influenced by coal-C.

\subsection{Conclusion}

Analysis of four reclaimed minesoils indicated that soil carbon increased with increasing time since reclamation. In the older minesoils, soil $\mathrm{C}$ budget was mostly dominate by the more stable humin fraction while in the younger soils the labile fraction was more dominant. Coal-C was not related to TSC. Higher coal-C in younger than older minesoils, indicated the lack of adequate time to develop soil horizons and accumulate pedogenic carbon in younger minesoils. Overall the sequential extraction procedure offered a relatively cheap and easy mean to extract coal-C and various soil carbon pools for minesoils. However, $\mathrm{C}$ mass balance revealed that some caution in needed to apply this method in younger minesoils and higher coal contents. Some effort should also have to be devoted in testing this method against other methods such as thermogravimetry and radiocarbon dating to distinguish soil $\mathrm{C}$ from coal-C. 


\section{References}

Akala, V.A., and R. Lal. 2000. Potential for mine land reclamation for soil organic carbon sequestration in Ohio. Land Degrad. Develop. 11:289-297.

Akala, V.A., and R. Lal. 2001. Soil organic pools and sequestration rates in reclaimed minesoils in Ohio. J. Environ. Qual. 30:2090-2104.

Barriuso, E., J.M. Portal, and F. Andreux 1987. Kinetics and acid hydrolysis of organic matter in humic-rich mountain soil. Can. J. Soil Sci. 67:647-658.

Collins, H.P., E.T. Elliott, K. Paustian, L.G. Bundy, W.A. Dick, D.R. Huggins, A.J.M. Smucker, and E.A. Paul. 2000. Soil carbon pools and fluxes in long-term corn belt agroecosystems. Soil Biol. Biochem. 32:157-168.

Dalmolin, R.S.D., C.N. Goncalves, D.P. Dick, H. Knicker, E. Klamt, and I. KogelKnabner. 2006. Organic matter characteristics and distribution in Ferralsol profiles in a climosequesnce in Southern Brazil. Eur. J. Soil Sci. 57:644-654.

Dick, D.C., H. Knicker, L.G. Avila, A.V. Inda. Jr., E. Giasson, and C.A. Bissani. 2006. Organic matter in constructed soils from a coal mining area in southern Brazil. Org. Geochem. 37:1537-1545:

Eusterhues, K., C. Rumpel,, M. Kleber, and I. Kogel-Knabner. 2003. Stabilisation of soil organic matter by interactions with minerals as revealed by mineral dissolution and oxidative degradation. Org. Geochem. 34:1591-1600.

Eusterhues, K., C. Rumpel,, M. Kleber, and I. Kögel-Knabner. 2005. Organo-mineral associations in sandy acidic forest soils: importance of iron oxides, mineral surface area and micropores. European J. Soil Sci. 56:753-763.

Eusterhues, K., C. Rumpel, and I. Kogel-Knabner. 2007. Composition and radiocarbon age of HF-resistant soil organic matter in Podzol and a Cambisol. Org. Geochem. 38:1356-1372.

Gelinas, Y., K.M. Prentice, J.A. Baldock, and J.I. Hedges. 2001. An improved thermal oxidation method for quantification of soot/graphitic black carbon in sediments and soils. Environ. Soil Tech. 35:3519-3525.

Haile-Mariam, S., W. Cheng, D.W. Johnson, J.T. Ball, and E.A. Paul. 2000. Use of carbon $^{13}$ and carbon ${ }^{14}$ to measure the effects of carbon dioxide and nitrogen 
fertilization on carbon dynamics in ponderosa pine. Soil Sci. Soc. Am. J. 64:19841993.

Jones D. L., and A.C. Edwards. 1998. Influence of sorption on the biological utilization of two simple carbon structures. Soil Biol. Biochem. 30:1895-1902.

Kaiser K., and G. Guggenberger. 2003. Mineral surfaces and soil organic matter. Eur. J. Soil Sci. 54:219-236.

Kaiser K., and G. Guggenberger. 2007. Sorptive stabilization of organic matter by microporous goethite: sorption into small pores vs. surface complexation. Eur. J. Soil Sci 58:45-59.

Kalbitz K., D. Schwesig, J. Rethemeyer, and E. Matzner. 2005. Stabilization of dissolved organic matter by sorption to the mineral soil. Soil Biol. Biochem. 37:1319-1331.

Kiem, R., H. Knicker, M. Körschens, I. Kögel-Knabner. 2000. Refractory organic carbon in C-depleted arable soils, as studied by 13C NMR spectroscopy and carbohydrate analysis. Org. Geochem. 31:655-668.

Maharaj, S., C.D. Barton, T.A.D. Karathanasis, H. Rowe, D. Rimmer, and M. Susan. 2007a. Distinguishing "New" from "Old" organic carbon in reclaimed coal mine sites using thermogravimetry: I. Methods development. Soil Sci. 172:292-302.

Maharaj, S., C.D. Barton, T.A.D. Karathanasis, H. Rowe, D. Rimmer, and M. Susan. 2007b. Distinguishing "New" from "Old" organic carbon in reclaimed coal mine sites using thermogravimetry: II. Field validation. Soil Sci. 172:302-312.

Mikutta, R., C. Mikutta, K. Kalbitz, T. Scheel, K. Kaiser, and R. Jahn. 2007. Biodegradation of forest floor organic matter bound to minerals via different binding mechanisms. Geochim. Cosmochim. Ac 71:2569-2590.

Mummey, D.L., P.D. Stahl, and J.S. Buyer. 2002. Soil microbiological properties 20 years after surface mine reclamation: Spatial analysis of reclaimed and undisturbed sites. Soil Biol Biochem. 34:1717-1725.

Naafs, D.F.W. and P.F. van Bergen. 2002. Effects of pH adjustments after base hydrolysis: Implications for understanding organic matter in soils. Geoderma. 106:191-217. 
Nierop, G.J.K., D.F.W. Naafs, and J.M. Verstraten. 2003. Occurance and distribution of ester-bound lipids in Dutch coastal dune soils along a pH gradient. Org. Geochem. 34:719-729.

Ostle, N.J., R. Bol, K.J. Petzke, and S.C. Jarvis. 1999. Compound specific 15N\%o values: Amino acids in grassland and arable soils. Soil Biol. Biochem. 31:1751-1755.

Paul, E.A., R.F. Follet, S.W. Leavitt, A. Halverson, G.A. Peterson, and D.J. Lyon. 1997. Radiocarbon dating for determination of soil organic carbon pool sizes and dynamics. Soil Sci. Soc Am. J. 61:1058-1067.

Paul, E.A., S.J. Morris, and S. Bohm, 2000. The determination of soil C pool sizes and turnover rates: Biophysical fractionation and tracers. In: Assessment Methods for Soil Carbon (eds R. Lal, J.M. Kimble, R.F. Follett \& B.A. Stewart), pp. 193-206. CRC Press, Boca Raton, FL

Paul, E.A., S.J. Morris, and S. Bohm. 2001a. The determination of soil C pool sizes and turnover rates: Biophysical fractionation and tracers. p. 193-205. In R. Lal et al (ed.) Assessment Methods for Soil Carbon. Lewis Publ. Boca Raton, FL.

Paul, E.A., H.P. Collins, and S.W. Leavitt. 2001b. Dynamics of resistant soil carbon of midwestern agricultural soils measured by naturally occurring $14 \mathrm{C}$ abundance. Geoderma, 104:239-256.

Paul, E.A., S.J. Morris, R.T. Conant, and A.F. Plante. 2006. Does the acid hydrolysisincubation method measure meaningful soil organic carbon pools? Soil Sci. Soc. Am. J. 70:1023-1035.

Schnitzer, M. and C.M. Preston. 1983. Effects of acid hydrolysis on the C-13 NMR spectra of humic substances. Plant and Soil Sci. 75:201-211.

Rumpel, C., H. Knicker, I. Kogel-Knabner, J.O. Skjemstad, and R.F. Huttl. 1998b. Types and chemical composition of organic matter in reforested lignite-rich mine soils. Geoderma 86:123-142.

Rumpel C., A. Seraphin, M. Dignac, W. Michaelis, K. Eusterhues, I. Kogel-Knabner. 2005. Effect of base hydrolysis on the chemical composition of organic matter of an acid forest soil. Org. Geochem. 36:239-249. 
Shukla, M.K., R. Lal, and M. H. Ebinger. 2005a. Physical and chemical properties of a minespoil eight years after reclamation in northeastern Ohio. Soil Sci. Soc. Am. J. 69:1288-1297.

Shrestha, R.K., and R. Lal. 2006. Ecosystem carbon budgeting and soil carbon sequestration in reclaimed minesoils. Environ. Int. 32:781-796.

Siewert, C. 2004. Rapid screening of soil properties using thermogravimetry. Soil Sci. Soc. Am. J. 68:1656-1661.

Skjemstad, J.O., P. Clarke, J.A. Taylor, J.M. Oades, and S.G. McClure. 1996. The chemistry and nature of protected carbon in soil. Aust. J. Soil Res. 34:251-271.

Spielvogel, S., J. Prietzel, and I. Kogel-Knabner. 2007. Changes of lignin phenols and neutral sugars in different soil types of a high-elevation forest ecosystem 25 years after forest dieback. Soil Biol. Biochem. 39:655-668.

Zegouagh, Y., S. Derene, M.F. Dignac, E. Baruiso, A. Mariotti, and C. Largeau. 2004. Demineralization of a crop soil by mild hydrofluoric acid treatment: Influence on organic matter composition and pyrolysis. J. Anal. Appl. Pyrolysis. 71:119-135.

Zimmerman A. R., J. Chorover K.W. Goyne, and S.L. Brantley. 2004. Protection of mesopore-adsorbed organic matter from enzymatic degradation. Environ. Sci. Technol. 38:4542-4548. 


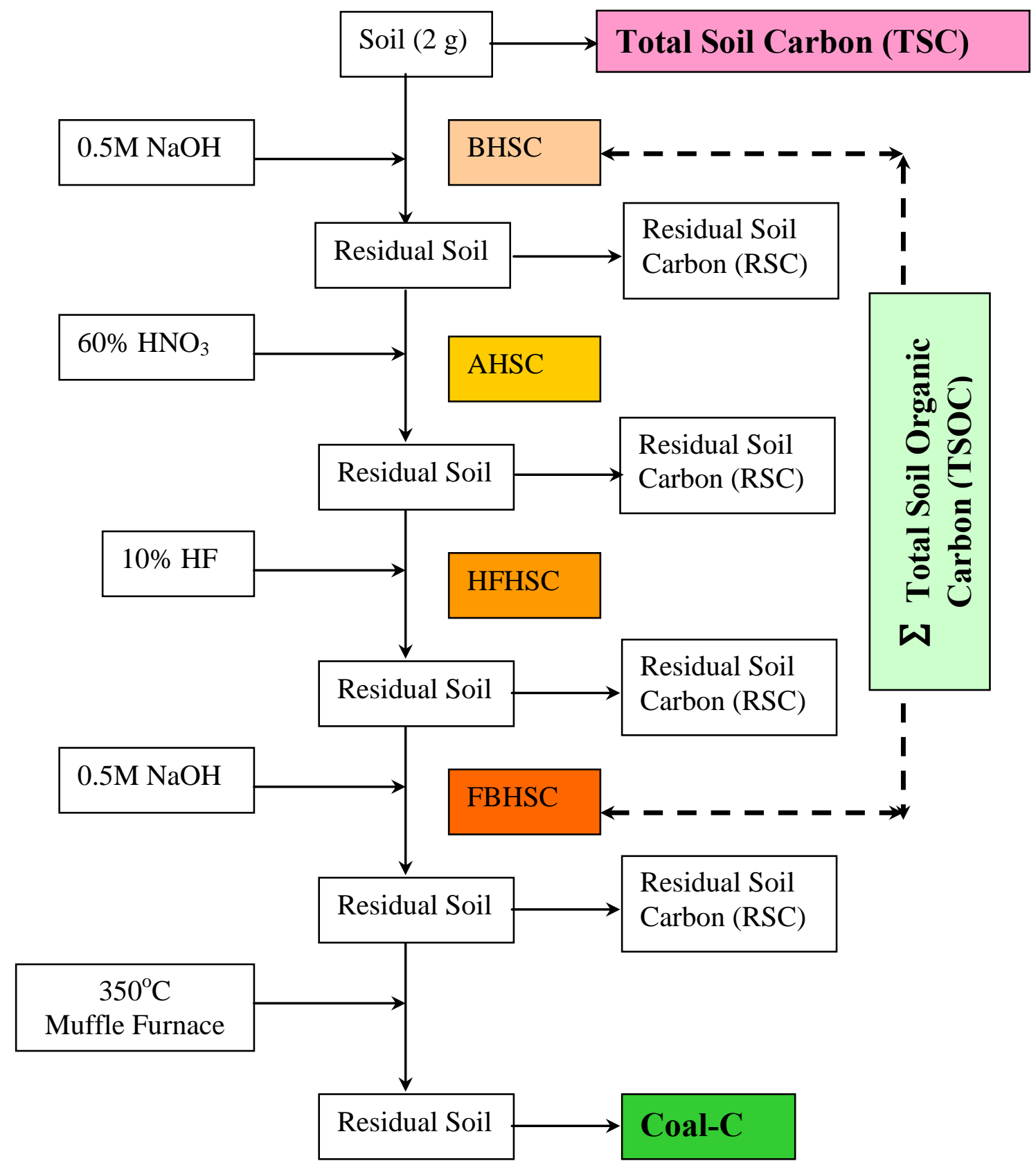

Figure 6-1: Sequential extraction scheme to isolate soil carbon (SC) pools and coal-C (BHSC $=$ Base-hydrolysable soil carbon, AHSC $=$ Acid-hydrolysable soil carbon, HFHSC $=10 \%$ HF-hydrolysable soil carbon, FBHSC $=$ Final basehydrolysable soil carbon) 
(a)

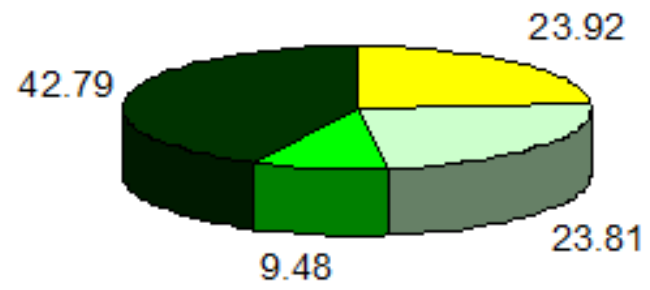

(c)

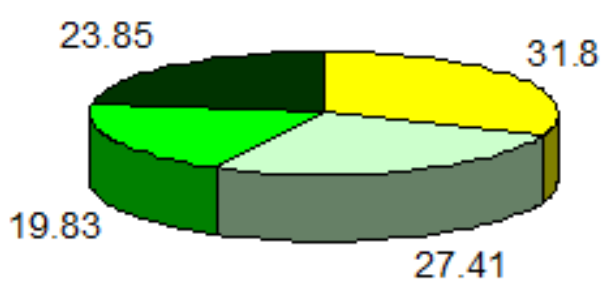

Bse Hydrolysable $\square$ Acid Hydrolysable $\square$ Mineral Bound (b)

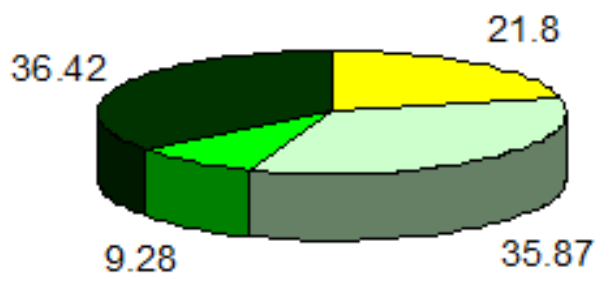

(d)

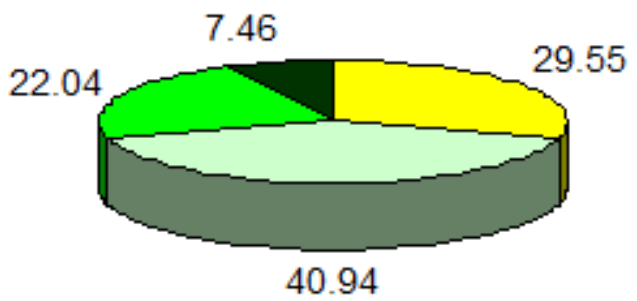

Humin

Figure 6-2: Percentages of various soil carbon pools in TSOC at (a) Mylan Park, (b) New Hill. (c) SK and (d) WVO1. 
Table 6-1: General characteristics of the reclaimed minesites included in the study

\begin{tabular}{|c|c|c|c|c|}
\hline Site Name & Mylan Park & New Hill & SK & WVO1 \\
\hline $\begin{array}{l}\text { Mining } \\
\text { Begins/Ends }\end{array}$ & $1982 / 1990$ & $2003 / 2005$ & $1996 / 1998$ & $2004 / 2005$ \\
\hline Coal Type & Waynesburg & Waynesburg & Waynesburg & Waynesburg \\
\hline $\begin{array}{l}\text { Method of } \\
\text { Mining }\end{array}$ & $\begin{array}{l}\text { Contour Mining, } \\
\text { Front end } \\
\text { loaders }\end{array}$ & $\begin{array}{l}\text { Contour } \\
\text { Mining, Front } \\
\text { end loaders }\end{array}$ & $\begin{array}{l}\text { Contour } \\
\text { Mining, Front } \\
\text { end loaders }\end{array}$ & $\begin{array}{l}\text { Contour } \\
\text { Mining, Front } \\
\text { end loaders }\end{array}$ \\
\hline $\begin{array}{l}\text { Type of } \\
\text { Overburden }\end{array}$ & $\begin{array}{l}70-80 \% \\
\text { Sandstone, rest } \\
\text { is shale }\end{array}$ & $\begin{array}{l}70-80 \% \\
\text { Sandstone, rest } \\
\text { is shale }\end{array}$ & $\begin{array}{l}\sim 80 \% \\
\text { Sandstone, rest } \\
\text { is shale }\end{array}$ & $\begin{array}{l}70-80 \% \\
\text { Sandstone, } \\
\text { rest is shale }\end{array}$ \\
\hline $\begin{array}{l}\text { Reclamation } \\
\text { Method }\end{array}$ & $\begin{array}{l}\text { Backfilled, } 3 " \\
\text { topsoil, grass } \\
\text { and legumes }\end{array}$ & $\begin{array}{l}\text { Backfilled, } 3 " \\
\text { topsoil, grass } \\
\text { and legumes }\end{array}$ & $\begin{array}{l}\text { Backfilled, } 8 " \\
\text { topsoil, grass } \\
\text { and legumes }\end{array}$ & $\begin{array}{l}\text { Backfilled, } 3 " \\
\text { topsoil, grass } \\
\text { and legumes }\end{array}$ \\
\hline
\end{tabular}


Table 6-2: Descriptive statistics for total soil carbon (TSC, $\mathrm{g} \mathrm{kg}^{-1}$ ) and total soil organic carbon (TSOC, $\mathrm{g} \mathrm{kg}^{-1}$ ) along the reclaimed minesoil chronosequence

\begin{tabular}{|c|c|c|c|c|c|c|c|c|}
\hline & $\begin{array}{l}\text { Minesoil } \\
\text { Name }\end{array}$ & Mean & Median & $\mathrm{CV} \%$ & Min & $\operatorname{Max}$ & Skewness & Kurtosis \\
\hline \multirow{4}{*}{ 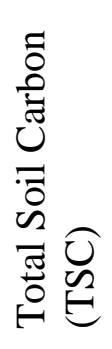 } & Mylan Park & $21.88^{\mathrm{a}}$ & 23.51 & 29.54 & 6.8 & 29.88 & -0.82 & -0.04 \\
\hline & New Hill & $17.72^{\mathrm{b}}$ & 17.72 & 26.83 & 9.8 & 29.47 & 0.40 & 0.12 \\
\hline & WVSK & $11.64^{\mathrm{c}}$ & 11.44 & 26.23 & 6.13 & 16.43 & 0.02 & -1.18 \\
\hline & WVO1 & $11.08^{\mathrm{c}}$ & 11.01 & 16.93 & 7.92 & 16.00 & 0.37 & 1.03 \\
\hline \multirow{4}{*}{ 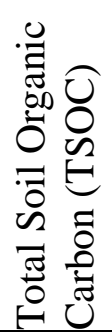 } & Mylan Park & $19.84^{\mathrm{a}}$ & 22.28 & 29.97 & 6.54 & 28.35 & -0.68 & -0.31 \\
\hline & New Hill & $14.09^{b}$ & 14.29 & 22.76 & 9.05 & 22.97 & 0.62 & 0.97 \\
\hline & WVSK & $8.31^{\mathrm{c}}$ & 7.80 & 29.33 & 4.85 & 12.30 & 0.06 & -1.41 \\
\hline & WVO1 & $7.84^{\mathrm{c}}$ & 7.68 & 24.07 & 4.40 & 12.18 & 0.16 & 0.09 \\
\hline
\end{tabular}

Different letters indicate significant $(p<0.05)$ difference. 
Table 6-3: Descriptive statistics of various SC pools $\left(\mathrm{g} \mathrm{kg}^{-1}\right)$ isolated by the sequential extraction procedure

\begin{tabular}{|c|c|c|c|c|c|c|c|c|}
\hline $\begin{array}{l}\text { Soil } \\
\text { Carbon } \\
\text { Pools }\end{array}$ & $\begin{array}{l}\text { Minesoil } \\
\text { Name }\end{array}$ & Mean & Median & $\mathrm{CV} \%$ & Min & Max & Skewness & Kurtosis \\
\hline \multirow{4}{*}{ 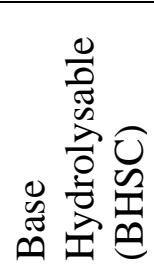 } & Mylan Park & $4.88^{\mathrm{a}}$ & 5.29 & 40.07 & 1.05 & 7.33 & -0.67 & -0.77 \\
\hline & New Hill & $3.09^{\mathrm{b}}$ & 3.30 & 30.69 & 1.68 & 5.36 & 0.41 & -0.33 \\
\hline & WVSK & $2.70^{\mathrm{c}}$ & 2.84 & 39.6 & 0.55 & 4.75 & -0.19 & -0.44 \\
\hline & WVO1 & $2.34^{\mathrm{c}}$ & 2.23 & 36.56 & 1.31 & 4.02 & 0.42 & -1.18 \\
\hline \multirow{4}{*}{ 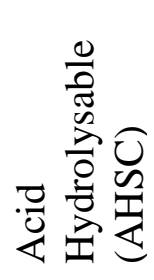 } & Mylan Park & $4.64^{\mathrm{a}}$ & 4.86 & 34.34 & 1.98 & 7.38 & -0.17 & -1.09 \\
\hline & New Hill & $4.94^{\mathrm{a}}$ & 4.93 & 15.37 & 3.09 & 6.24 & -0.19 & 0.05 \\
\hline & WVSK & $2.19^{\mathrm{b}}$ & 2.28 & 19.41 & 1.24 & 2.96 & -0.28 & -0.13 \\
\hline & WVO1 & $3.19^{b}$ & 3.29 & 24.2 & 1.71 & 4.68 & -0.19 & -0.35 \\
\hline \multirow{4}{*}{ 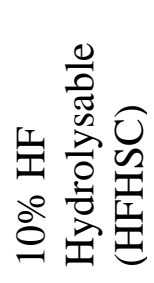 } & Mylan Park & $1.76^{\mathrm{a}}$ & 1.79 & 45.46 & 0.21 & 3.54 & -0.09 & -0.02 \\
\hline & New Hill & $1.23^{\mathrm{a}}$ & 1.28 & 49.18 & 0.41 & 2.69 & 0.40 & -0.20 \\
\hline & WVSK & $1.48^{\mathrm{a}}$ & 1.38 & 40.15 & 0.65 & 2.69 & 0.44 & -0.55 \\
\hline & WVO1 & $1.72^{\mathrm{a}}$ & 1.62 & 30.44 & 0.98 & 3.05 & 0.74 & 0.59 \\
\hline \multirow{4}{*}{ 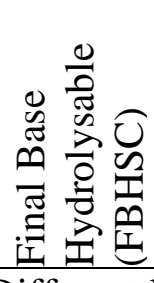 } & Mylan Park & $8.56^{\mathrm{a}}$ & 9.55 & 31.52 & 1.45 & 11.9 & -1.06 & 0.65 \\
\hline & New Hill & $4.83^{b}$ & 5.3 & 32.02 & 2.09 & 8.68 & 0.06 & 0.473 \\
\hline & WVSK & $1.93^{\mathrm{c}}$ & 1.73 & 47.76 & 0.42 & 3.52 & 0.19 & -1.23 \\
\hline & WVO1 & $0.60^{\mathrm{d}}$ & 0.58 & 41.02 & 0.15 & 1.22 & 0.36 & 0.65 \\
\hline
\end{tabular}

Different letters indicate significant $(p<0.05)$ difference within each HSC pool. 
Table 6-4: Descriptive statistics for coal- $\mathrm{C}\left(\mathrm{g} \mathrm{kg}^{-1}\right)$ along the minesoil chronosequence

\begin{tabular}{lccccccc}
\hline $\begin{array}{l}\text { Minesoil } \\
\text { Name }\end{array}$ & Mean & Median & CV \% & Min & Max & Skewness & Kurtosis \\
\hline Mylan Park & $0.59^{\mathrm{a}}$ & 0.42 & 82.08 & 0.01 & 1.93 & 1.03 & 0.66 \\
New Hill & $1.76^{\mathrm{a}}$ & 1.24 & 79.62 & 0.01 & 3.94 & 0.35 & -1.50 \\
WVSK & $1.68^{\mathrm{a}}$ & 1.47 & 51.06 & 0.36 & 3.19 & 0.28 & -1.11 \\
WVO1 & $1.46^{\mathrm{a}}$ & 1.41 & 63.54 & 0.02 & 3.25 & 0.33 & -0.65 \\
\hline
\end{tabular}

Different letters indicate significant $(p<0.05)$ difference. 
Table 6-5: Descriptive statistics for total recovery (\%) for reclaimed minesoil

\begin{tabular}{lccccccc}
\hline $\begin{array}{l}\text { Minesoil } \\
\text { Name }\end{array}$ & Mean & Median & CV \% & Min & Max & Skewness & Kurtosis \\
\hline Mylan Park & $93.94^{\mathrm{a}}$ & 96.06 & 6.01 & 78.48 & 99.51 & -1.67 & 2.35 \\
New Hill & $89.98^{\mathrm{ab}}$ & 89.26 & 5.66 & 81.01 & 101 & 0.30 & 0.1 \\
WVSK & $85.49^{\mathrm{b}}$ & 86.70 & 5.21 & 6.10 & 66.69 & 0.68 & -2.27 \\
WVO1 & $83.77^{\mathrm{b}}$ & 84.59 & 3.37 & 77.54 & 88.24 & -0.58 & 0.00 \\
\hline
\end{tabular}

Different letters indicate significant $(p<0.05)$ difference. 
Table 6-6: Regression coefficients $\left(\mathrm{R}^{2}\right)$ between TSC and SC pools including coal-C ( $p<$ $0.05)$.

\begin{tabular}{|c|c|c|c|c|c|c|c|}
\hline & Minesoil Name & $\begin{array}{c}\mathrm{TSC} \\
\left(\mathrm{g} \mathrm{kg}^{-1}\right)\end{array}$ & $\begin{array}{c}\text { BHSC } \\
\left(\mathrm{g} \mathrm{kg}^{-1}\right)\end{array}$ & $\begin{array}{l}\text { AHSC } \\
\left(\mathrm{g} \mathrm{kg}^{-1}\right)\end{array}$ & $\begin{array}{c}\text { HFHSC } \\
\left(\mathrm{g} \mathrm{kg}^{-1}\right)\end{array}$ & $\begin{array}{l}\text { FBHSC } \\
\left(\mathrm{g} \mathrm{kg}^{-1}\right)\end{array}$ & $\begin{array}{c}\text { Coal } \\
\left(\mathrm{g} \mathrm{kg}^{-1}\right)\end{array}$ \\
\hline \multirow{4}{*}{$\begin{array}{l}\text { TSC } \\
\left(\mathrm{g} \mathrm{kg}^{-1}\right)\end{array}$} & Mylan Park & \multirow{4}{*}{1} & $0.86^{*}$ & $0.57^{*}$ & 0.12 & $0.88^{*}$ & 0.00 \\
\hline & New Hill & & 0.57 & $0.60^{*}$ & 0.46 & $0.76^{*}$ & 0.34 \\
\hline & SK & & $0.73^{*}$ & $0.57^{*}$ & 0.30 & $0.66^{*}$ & 0.30 \\
\hline & WVO1 & & 0.24 & $0.76^{*}$ & 0.51 & $0.57^{*}$ & 0.01 \\
\hline \multirow{4}{*}{$\begin{array}{l}\text { BHSC } \\
\left(\mathrm{g} \mathrm{kg}^{-1}\right)\end{array}$} & Mylan Park & & \multirow{4}{*}{1} & 0.44 & 0.03 & 0.70 & 0.03 \\
\hline & New Hill & & & 0.31 & 0.44 & 0.35 & 0.03 \\
\hline & SK & & & 0.54 & 0.06 & 0.45 & 0.09 \\
\hline & WV01 & & & 0.15 & 0.15 & 0.11 & 0.34 \\
\hline \multirow{4}{*}{$\begin{array}{l}\text { AHSC } \\
\left(\mathrm{g} \mathrm{kg}^{-1}\right)\end{array}$} & Mylan Park & & & \multirow{4}{*}{1} & 0.01 & 0.48 & 0.05 \\
\hline & New Hill & & & & 0.07 & 0.46 & 0.07 \\
\hline & SK & & & & 0.13 & 0.49 & 0.06 \\
\hline & WVO1 & & & & 0.30 & $0.60^{*}$ & 0.00 \\
\hline \multirow{4}{*}{$\begin{array}{l}\text { HFHSC } \\
\left(\mathrm{g} \mathrm{kg}^{-1}\right)\end{array}$} & Mylan Park & & & & \multirow{4}{*}{1} & 0.08 & 0.16 \\
\hline & New Hill & & & & & 0.24 & 0.13 \\
\hline & SK & & & & & 0.12 & 0.00 \\
\hline & WV01 & & & & & 0.49 & 0.07 \\
\hline \multirow{4}{*}{$\begin{array}{l}\text { FBHSC } \\
\left(\mathrm{g} \mathrm{kg}^{-1}\right)\end{array}$} & Mylan Park & & & & & \multirow{4}{*}{1} & 0.00 \\
\hline & New Hill & & & & & & 0.14 \\
\hline & SK & & & & & & 0.12 \\
\hline & WVO1 & & & & & & 0.04 \\
\hline \multirow{4}{*}{$\begin{array}{l}\text { Coal-C } \\
\left(\mathrm{g} \mathrm{kg}^{-1}\right)\end{array}$} & Mylan Park & & & & & & \multirow{4}{*}{1} \\
\hline & New Hill & & & & & & \\
\hline & SK & & & & & & \\
\hline & WVO1 & & & & & & \\
\hline
\end{tabular}

\footnotetext{
*Significant $(p \leq 0.05)$ relationship between the measured variables.
} 


\section{CHAPTER 7: Conclusion}

The results indicated that certain soil properties can be more variable in undisturbed soils than minesoils. Therefore determination of sample size to characterize any soil property should be site-specific and property-specific. However, more research is needed to look into the spatial dependence of soil properties and their relationships with environmental and landscape parameters to characterize the soil properties. Some effort may also be devoted to identify the relationship between minesoil ages (time since reclamation) and variability.

The study shows that with increasing time since reclamation, minesoils can sequester significant amounts of carbon and influenced several soil properties. For example, CEC was more dependent on SOC than clays in the older than younger minesoils. A detailed characterization of soil minerals, especially the clays and Fe-, Aloxy(hydroxide) phases, might be interesting in this regard. Characterization of these mineral phases might also be helpful in understanding their importance in stabilizing SOC and therefore SOC sequestration processes in these soils. Calculated rates suggested that the greatest SOC sequestration was achieved in the first decade since reclamation along the chronosequence. However, more evidence is necessary to support this observation and a good way could be to locate additional reclaimed minesoils with similar soil forming characteristics but having time since reclamation in between the oldest and the middle phases of this chronosequence.

Minesoils with different time since reclamation differed significantly in SOC molecular properties and the results suggested that this could be linked to SOC dynamics. Over time, increased humification and degree of aromaticity of SOC molecules observed in the older minesoils of this chronosequence, could result in SOC stabilization leading to its long term preservation and sequestration.

Relative proportions of various soil $\mathrm{C}$ fractions differed significantly among the minesoils. Younger minesoils had a predominance of the labile $\mathrm{C}$ fraction while soil $\mathrm{C}$ in the older minesoils was mostly made up of the stable $\mathrm{C}$ fractions. Coal- $\mathrm{C}$ appeared to be an insignificant part of the total soil $\mathrm{C}$ budget in this minesoil chronosequence except for the most newly reclaimed site. The soil $\mathrm{C}$ fractions, however, were based on effectiveness 
of various extractants isolate the $\mathrm{C}$ pools and therefore should be considered operationally defined. Radiocarbon dating of the individual $\mathrm{C}$ pools might offer more insight into their residence times and hence provide a better sense of old vs. new $\mathrm{C}$. Research on the molecular make up of these various $\mathrm{C}$ pools might also be interesting to relate the idea of $\mathrm{C}$ quality with stability. Other methods, such as thermogravimetry, might also be helpful to distinguish between soil $\mathrm{C}$ of different origin. Some effort could also be devoted in looking into the microbial communities and their role in organic matter degradation and recycling in these soils. 